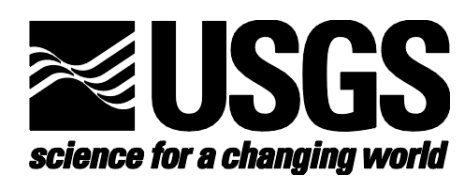

\title{
Modified Mercalli Intensity Assignments for the May 16, 1909, Northern Plains Earthquake
}

By W.H. Bakun ${ }^{1}$, M.C. Stickney ${ }^{2}$, G. Rogers ${ }^{3}$, and J. Ristau ${ }^{4}$

Open-File Report 2010-1185

1 U.S. Geological Survey, Menlo Park, Calif., USA

2 Montana Bureau of Mines and Geology, Butte, Mont., USA

3 Geological Survey of Canada, Victoria, BC, Canada

${ }^{4}$ Geological Survey of Canada, Victoria, BC, Canada (now at GNS Science, Lower Hutt, New Zealand)

U.S. Department of the Interior U.S. Geological Survey 


\section{U.S. Department of the Interior KEN SALAZAR, Secretary}

\section{U.S. Geological Survey}

Marcia K. McNutt, Director

U.S. Geological Survey, Reston, Virginia: 2010

For product and ordering information:

World Wide Web: http://www.usgs.gov/pubprod/

Telephone: 1-888-ASK-USGS

For more information on the USGS - the Federal source for science about the Earth, its natural and living resources, natural hazards, and the environment: World Wide Web:

http://www.usgs.gov/

Telephone: 1-888-ASK-USGS

Suggested citation:

Bakun, W.H., Stickney, M.C., Rogers, G., and Ristau, J., 2010, Modified Mercalli intensty assignments for the May 16, 1909, Northern Plains earthquake: U.S. Geological Survey Open-File Report 2010-1185, v. 1.1, 96 p., available at http://pubs.usgs.gov/of/2010/1185/.

Any use of trade, product, or firm names is for descriptive purposes only and does not imply endorsement by the U.S. Government. 


\section{Contents}

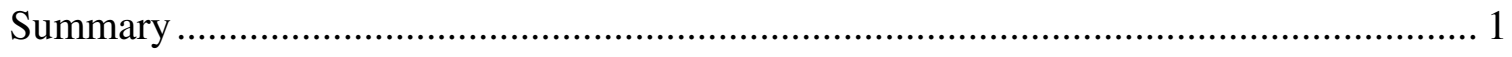

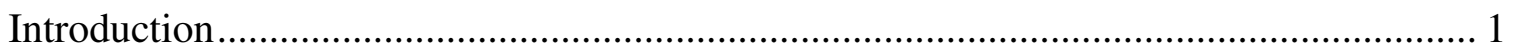

Nuttli's Assessment of the 1909 Earthquake ............................................................. 1

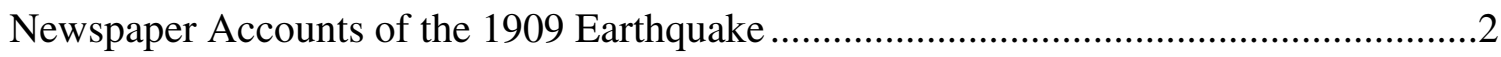

MMI Assignments for the 1909 Earthquake................................................................ 2

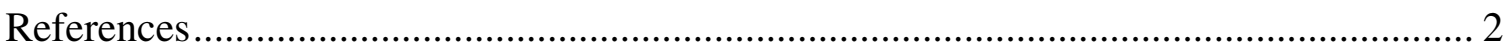

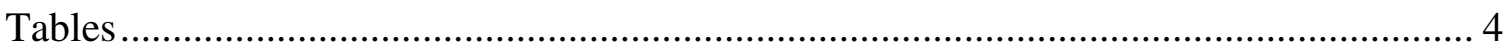

Appendix A. Newspaper Accounts for the 1909 Northern Plains Earthquake................. 23

Appendix B. Newspaper accounts from Saskatchewan archives .................................. 45

Appendix C. Newspaper accounts from Manitoban archives ........................................... 61

\section{Figure}

1. Nuttli's (1976 0 isoseismal map for the May 16, 1909 Northern Plains

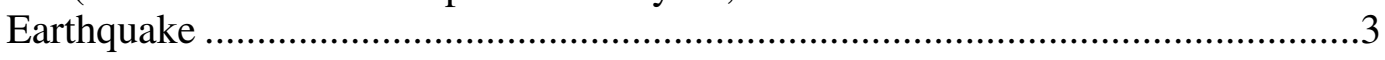

\section{Tables}

1. Nuttli's (1976) MMI assignments for the 16 May 1909 Earthquake ..............................4

2. Index for newspaper accounts (Appendix A) for the 1909 Northern Plains

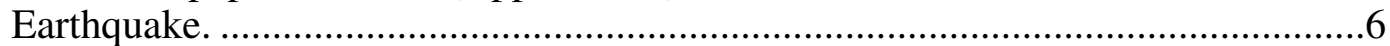

3. MMI assignments for the May 16, 1909 Northern Plains Earthquake ............................

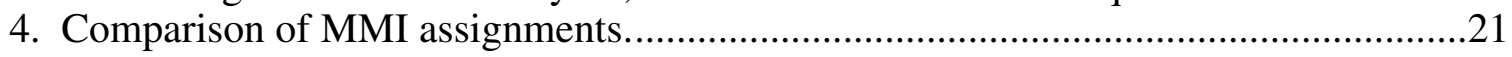




\section{Summary}

We use newspaper accounts from the United States and Canada to assign modified Mercalli intensity (MMI) at 90 towns for the May 16, 1909 Northern Plains earthquake. Our MMI assignments generally are consistent with those plotted on Nuttli's (1976) isoseiemal map. The earthquake was felt over more than $1,500,000 \mathrm{~km}^{2}$ in the states of Minnesota, Montana, North Dakota, South Dakota, and Wyoming and the provinces of Alberta, Manitoba, Ontario, and Saskatchewan.

\section{Introduction}

The 1909 Northern Plains earthquake occurred at about 09:15PM local time on May 15, 1909 (May 16, 1909 04:15 UTC). The 1909 earthquake is the largest historical event in the northern plains of the United States and Canada and is important in understanding the seismotectonics of northeast Montana, northwest North Dakota, and southern Saskatchewan. Instrumental data are not sufficient to calculate an epicenter, but amplitudes recorded on a Bosch-Omori seismograph at Ottawa ( $2500 \mathrm{~km}$ ) are consistent with an $\mathrm{m}_{\mathrm{b}}$ of about 5.5 (Horner and others, 1973). H.F. Reid's initial location, based on intensity assignments, is in southern Saskatchewan (Heck and Eppley, 1958). Horner and Hasegawa (1978) argued that the intensity data can also be rationalized by sources in northeastern-most Montana and adjoining North Dakota and located the epicenter at $49^{\circ} \mathrm{N}, 104^{\circ} \mathrm{W}$ where Montana and North Dakota meet at the U.S.-Canada border. Stover and Coffman (1993) adopted this arbitrary location and listed the 1909 event as the only historical North Dakota earthquake. The purpose of this report is to archive accounts and MMI assignments of this important earthquake. The analysis of these data and implications for seismic hazard analysis are described in Bakun and others (in press).

\section{Nuttli's Assessment of the 1909 Earthquake}

The U.S. Army Corps of Engineers (COE) prepared a report in 1976 on the seismic safety of the Fort Peck Dam on the Missouri River in northeast Montana (Marcuson and Krinitzsky, 1976). Appendix B of that report, "Design earthquakes for Fort Peck, Montana," was prepared by Otto W. Nuttli. We refer to Appendix B of Marcuson and Krinitzaky (1976) as Nuttli (1976). Nuttli (1976) published an isoseismal map (fig. 1) of MMI assignments (Wood and Neumann, 1931) for the 1909 Northern Plains earthquake based on his collection of newspaper accounts in the U.S. and on Canadian newspaper accounts forwarded to him by Ann Stevens of the Canadian Geological Survey. Unfortunately, Nuttli's file of descriptions of the earthquake effects apparently has been lost. We have taken the location place names, coordinates, and MMI assignments from figure 1 to reconstruct Nuttli's list of intensity assignments (table 1).

Nuttli (1976) noted that the maximum MMI was VI and the felt area of the 1909 earthquake exceeded $1,500,000 \mathrm{~km}^{2}$. The relatively large felt area and small maximum intensity is similar in these respects to earthquakes that occur in the central United States. Using an unpublished relation between felt area and $\mathrm{m}_{\mathrm{b}}$ for earthquakes in the central U.S., Nuttli (1976) noted that the minimum felt area for the 1909 earthquake corresponded to an $\mathrm{m}_{\mathrm{b}} 5.3$ event. The coordinates of the center of the innermost isoseismal (fig. 1) is $50^{\circ} \mathrm{N}, 104^{\circ} \mathrm{W}, 1^{\circ}$ north of the U.S.-Canada border and the location assumed by Stover and Coffman (1993). 


\section{Newspaper Accounts of the 1909 Earthquake}

We searched newspaper archives in the U.S. and Canada for accounts of the 1909 earthquake. Relevant newspaper accounts from archives in the U.S., Saskatchewan, and Manitoba are listed in appendices A, B, and C, respectively. Accounts pertinent to our assignment of intensities are underlined in the appendices. Table 2 is a combined index for appendices A, B, and C. The pertinent accounts (underlined in the appendices) are repeated in table 3 .

\section{Assignments for the 1909 Earthquake}

Our MMI assignments (table 3) are based on the newspaper accounts in the appendices. We use half-integer MMI values, for example, MMI IV-V represents accounts clearly sufficient for assigning MMI IV and containing some descriptions suggesting MMI V. Table 3 lists 90 MMI assignments.

We could not find accounts for four sites (Grand Forks, North Dakota; Hamburg (Lemburg?), Saskatchewan; Regina, Montana; and St. Paul, Minnesota) for which Nuttli (1976) showed MMI assignments. Whereas Nuttli's (1976) assigned an MMI V at Balgonie, Saskatchewan, the effects at Balgonie described in the Regina Morning Leader (appendix B) are not sufficient for us to assign an intensity value.

MMI were assigned by Nuttli (1976) at 50 towns where there are sufficient accounts in the appendices to assign MMI independently (table 4). MMI assignments are the same at 27 of the sites and differ by 0.5 intensity unit at 12 sites (table 4). Nuttli's (1976) MMI assignments and our MMI assignments at the 50 sites in table 4 generally are consistent.

\section{References}

Bakun, W.H. and Wentworth, C.M., 1997, Estimating earthquake location and magnitude from seismic intensity data: Seismological Society of America Bulletin, no. 87, p. $1502-1521$.

Bakun, W.H., Stickney, M.C., and Rogers, G., in press, The May 16, 1909, northern Great Plains earthquake: Seismological Society of America Bulletin, submitted for 2011.

Heck, N.H. and Eppley, R.A., 1958, Earthquake history of the United States, Part 1, continental U.S. and Alaska (exclusive of California and western Nevada), revised edition (through 1956): U.S. Department of Commerce, Coast and Geodetic Survey, Publication, no. 41-1, 80 p.

Horner, R.B., Stevens, A.E., and Hasegawa, H.S., 1973, The Bengough, Saskatchewan, earthquake of July 26, 1972: Canadian Journal of Earth Sciences, no. 10, p. 18051821.

Horner, R.B., and Hasegawa, H.S., 1978, The seismotectonics of southern Saskatchewan: Canadian Journal of Earth Sciences, no. 15, p. 1341-1355.

Marcuson, W.F. III, and Krinitzsky, E.L., 1976, Dynamic analysis of Fort Peck Dam: U.S. Army Corps of Engineers Final Report, no. S-76-1, 298 p.

Nuttli, O.W., 1976, Design earthquakes for Fort Peck, Montana (Appendix B), in Dynamic analysis of Fort Peck Dam, W.F. Marcuson III and E. L. Krinitzsky (authors): U.S. Army Corps of Engineers Final Report, no. S-76-1, 298 p.

Stover, C.W. and Coffman, J.L., 1993, Seismicity of the United States, 1568-1989 (Revised): U.S. Geological Survey Professional Paper, no. 1527, 418 p. 
Wood, H.O., and Neumann, F., 1931, Modified Mercalli Intensity Scale of 1931: Seismological Society of America Bulletin, no. 21, p. 277-283.

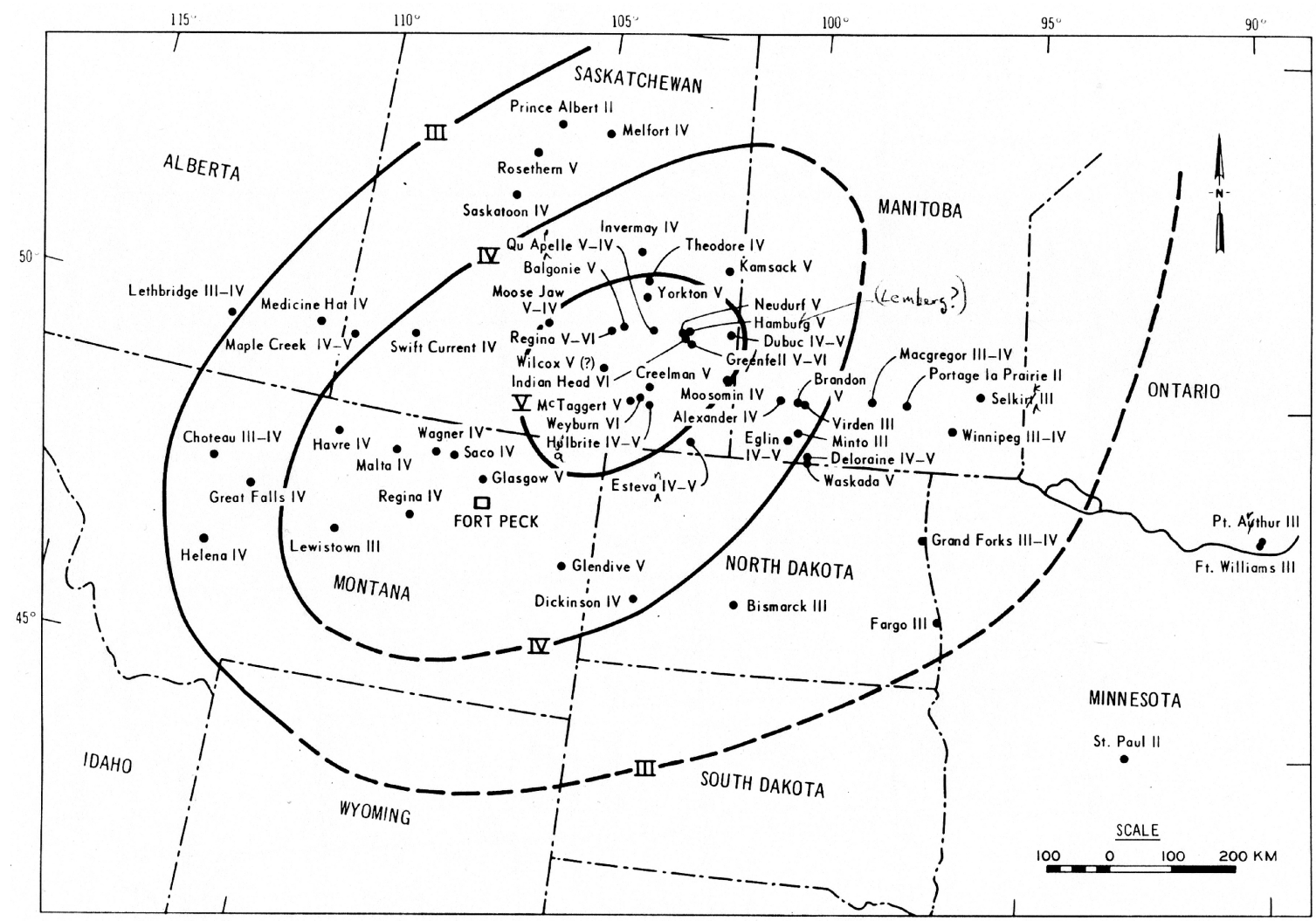

Figure 1. Nuttli's (1976) isoseismal map for the May 16, 1909, earthquake [Figure B3 of Marcuson and Krinitzsky (1976)]. 


\section{Table 1. Nuttli's (1976) MMI assignments for the May 16, 1909 earthquake (taken from fig. 1).}

\begin{tabular}{|c|c|c|c|c|}
\hline Place & State/ Province & Latitude $\left({ }^{\circ} \mathrm{N}\right)$ & Longitude $\left({ }^{\circ} \mathrm{W}\right)$ & MMI \\
\hline Alexander & Manitoba & 49.83 & 100.33 & IV \\
\hline Balgonie & Saskatchewan & 50.50 & 104.43 & V \\
\hline Bismarck & North Dakota & 46.80 & 100.78 & III \\
\hline Brandon & Manitoba & 49.83 & 99.95 & V \\
\hline Choteau & Montana & 47.80 & 112.17 & III-IV \\
\hline Creelman & Saskatchewan & 49.82 & 103.32 & V \\
\hline Debuc & Saskatchewan & 50.68 & 102.47 & IV-V \\
\hline Deloraine & Manitoba & 49.18 & 100.50 & IV-V \\
\hline Dickinson & North Dakota & 46.87 & 102.78 & IV \\
\hline Elgin & Manitoba & 49.43 & 100.27 & IV-V \\
\hline Estevan & Saskatchewan & 49.15 & 102.98 & IV-V \\
\hline Fargo & North Dakota & 46.87 & 96.78 & III \\
\hline Ft Williams & Ontario & 48.18 & 88.63 & III \\
\hline Glasgow & Montana & 48.18 & 106.63 & $\mathrm{~V}$ \\
\hline Glendive & Montana & 47.10 & 104.70 & V \\
\hline Grand Forks & North Dakota & 47.93 & 97.43 & III-IV \\
\hline Great Falls & Montana & 47.50 & 111.30 & IV \\
\hline Grenfell & Saskatchewan & 50.40 & 102.93 & V-VI \\
\hline Halbrite & Saskatchewan & 49.50 & 103.57 & IV-V \\
\hline Hamburg (Lemberg?) & Saskatchewan & 50.73 & 103.17 & V \\
\hline Havre & Montana & 48.55 & 109.68 & IV \\
\hline Helena & Montana & 46.58 & 112.03 & IV \\
\hline Indian Head & Saskatchewan & 50.53 & 103.68 & VI \\
\hline Invermay & Saskatchewan & 51.78 & 103.15 & IV \\
\hline Kamsack & Saskatchewan & 51.57 & 101.85 & $\mathrm{~V}$ \\
\hline Lethbridge & Alberta & 49.72 & 112.80 & III-IV \\
\hline Lewistown & Montana & 47.05 & 109.42 & III \\
\hline Macgregor & Manitoba & 49.95 & 98.80 & III-IV \\
\hline Malta & Montana & 48.35 & 107.87 & IV \\
\hline Maple Creek & Saskatchewan & 49.92 & 109.47 & IV-V \\
\hline McTaggert & Saskatchewan & 49.73 & 104.01 & V \\
\hline Medicine Hat & Alberta & 50.05 & 110.68 & IV \\
\hline Melfort & Saskatchewan & 52.87 & 104.63 & IV \\
\hline Minto & Manitoba & 49.40 & 100.00 & III \\
\hline Moose Jaw & Saskatchewan & 50.38 & 105.58 & V-VI \\
\hline Moosomin & Saskatchewan & 50.15 & 101.68 & IV \\
\hline Neudurf & Saskatchewan & 50.73 & 103.03 & V \\
\hline Portage la Prairie & Manitoba & 49.97 & 98.33 & III \\
\hline Prince Albert & Saskatchewan & 53.25 & 105.75 & III \\
\hline Pt. Arthur & Ontario & 48.22 & 88.61 & III \\
\hline Qu Appelle & Saskatchewan & 50.55 & 103.90 & V-VI \\
\hline Regina & Montana & 47.91 & 107.92 & IV \\
\hline Regina & Saskatchewan & 50.50 & 104.63 & IV-V \\
\hline Rosenthern & Saskatchewan & 52.66 & 106.34 & V \\
\hline Saco & Montana & 48.45 & 107.33 & IV \\
\hline Saskatoon & Saskatchewan & 52.17 & 106.67 & IV \\
\hline Selkirk & Manitoba & 50.17 & 96.87 & III \\
\hline St. Paul & Minnesota & 44.93 & 93.08 & III \\
\hline
\end{tabular}




\section{Table 1. Nuttli's (1976) MMI assignments for the May 16, 1909 earthquake (taken from fig. 1).}

\begin{tabular}{llllc} 
Place & State/ Province & Latitude $\left({ }^{\circ} \mathrm{N}\right)$ & Longitude $\left({ }^{\circ} \mathrm{W}\right)$ & MMI \\
\hline Swift Current & Saskatchewan & 50.28 & 107.82 & IV \\
Theodore & Saskatchewan & 51.43 & 102.97 & IV \\
Virden & Manitoba & 49.83 & 100.95 & III \\
Wagner & Montana & 48.37 & 108.07 & IV \\
Waskada & Manitoba & 49.08 & 100.82 & V \\
Weyburn & Saskatchewan & 49.65 & 103.85 & VI \\
Wilcox & Saskatchewan & 50.15 & 104.73 & V \\
Winnipeg & Manitoba & 49.88 & 97.17 & III-IV \\
Yorkton & Saskatchewan & 51.20 & 102.48 & $\mathrm{~V}$ \\
& & & \\
\hline
\end{tabular}


Table 2. Index of newspaper accounts, May 16, 1909, earthquake

Town

Aberdeen, SD

Alameda, SASK

Battleford, SASK

Belle Fourche, SD

Belt Valley, MT

Billings, MT

Bismarck, ND

Brandon, MAN

Canora, SASK

Carberry, MAN

Carberry, MAN

Carman, MAN

Chester, MT

Chinook, MT

Choteau, MT

Conrad, MT

Craik, SASK

Culbertson, MT

Culbertson, MT

Cupar, SASK

Dauphin, MAN

Dauphin, MAN

Deadwood, SD

Deloraine, MAN

Dickinson, ND

Fargo, ND

Fargo, ND

Forsyth, MT

Fort Benton, MT

Glasgow, MT

Glasgow, MT

Glendive, MT

Glendive, MT

Great Falls, MT

Great Falls, MT

Harlem, MT

Harlowton, MT

Havre, MT

Helena, MT

Hinsdale, MT

Kamsack, SASK

Livingston, MT

Lloydminster, MAN

Maple Creek, SASK

Miles City, MT

Miles City, MT

Milestone, SASK

Minnedosa, MAN
Newspaper

Appendix

Aberdeen Daily American A

Alameda Dispatch B

Battleford Saskatchewan Herald B

Northwest Post A

Belt Valley Times A

Billings Daily Gazette A

Bismarck Daily Tribune A

Brandon Weekly Sun $\quad$ C

Canora Advertiser B

Carberry Express C

Carberry News C

Carman Standard

-

Chinook Opinion $\quad$ A

Choteau Acantha A

Conrad Observer A

Craik Weekly News B

Culbertson Searchlight A

Culbertson Republican A

Cupar Herald \& North Qu'Appelle Chronicle B

Dauphin Herald C

Dauphin Press

Daily Pioneer Times A

Deloraine Times $\quad$ C

Dickinson Press A

Fargo Forum and Daily Republican A

Fargo Forum A

Forsyth Times A

River Press Weekly A

Glasgow Democrat A

Valley County News $\quad$ A

Yellowstone Monitor A

Dawson County Review A

Great Falls Daily Tribune A

Great Falls Daily Leader A

Harlem News A

Harlowton News A

Havre Plaindealer A

Helena Independent A

Montana Homestead A

Kamsack Times B

Livingston Enterprise $\quad$ A

Lloydminster Times $\quad$ C

Maple Creek News B

Stockgrowers Journal A

Daily Yellowstone Journal A

Milestone Mail B

Minnedosa Tribune $\quad$ C 
Table 2. Index of newspaper accounts, May 16, 1909, earthquake

\begin{tabular}{|c|c|c|}
\hline Town & Newspaper & Appendix \\
\hline Minto, MAN & Minto Packet & $\mathrm{B}$ \\
\hline Minto, MAN & Minto Riverside Review & $\mathrm{C}$ \\
\hline Mondak, MT & - & $A$ \\
\hline Moose Jaw, SASK & Moose Jaw Evening Times & B \\
\hline Morden, MAN & Morden Chronicle & C \\
\hline Morden, MAN & Morden Empire & C \\
\hline Neepawa, MAN & Neepawa Press & C \\
\hline Neepawa, MAN & Neepawa Register & C \\
\hline Portage la Prairie, MAN & Portage la Prairie Evening Review & C \\
\hline Qu'Appelle, SASK & Qu'Appelle Progress & B \\
\hline Rapid City, SD & Rapid City Daily Journal & $A$ \\
\hline Regina, SASK & Regina Daily Standard & $\mathrm{B}$ \\
\hline Regina, SASK & Regina Morning Leader & B \\
\hline Regina, SASK & Regina The West & $\mathrm{B}$ \\
\hline Roblin, MAN & Roblin Messenger & $\mathrm{C}$ \\
\hline Saskatoon, SASK & Saskatoon Daily Phoenix & B \\
\hline Selkirk, MAN & Selkirk Expositor & $\mathrm{C}$ \\
\hline Selkirk, MAN & Selkirk Weekly Record & C \\
\hline Sidney, MT & Sidney Herald & A \\
\hline Strassburg, SASK & Strassburg Mountaineer & $\mathrm{B}$ \\
\hline Stroughton, SASK & Stoughton Times & B \\
\hline Swan River, MAN & Swan River Star & $\mathrm{C}$ \\
\hline Terry, MT & Terry Tribune & A \\
\hline Treherne, MAN & Treherne Times & C \\
\hline Virden, MAN & Virden Empire Advance & $\mathrm{C}$ \\
\hline Whitewood, SASK & Whitewood Herald & $\mathrm{B}$ \\
\hline Wibaux, MT & Wibaux Pioneer & $A$ \\
\hline Williston, ND & Williston Daily Herald & $A$ \\
\hline Williston, ND & Williston Graphic & $A$ \\
\hline Winnipeg, MAN & Winnipeg Telegram & $\mathrm{C}$ \\
\hline Winnipeg, MAN & Winnipeg Tribune & $\mathrm{C}$ \\
\hline Winnipeg, MAN & Manitoba Free Press & $\mathrm{C}$ \\
\hline Wolseley, SASK & Wolseley News & B \\
\hline Yorkton, SASK & Yorkton Enterprise & $\mathrm{B}$ \\
\hline Zortman, MT & Little Rockies Miner & A \\
\hline
\end{tabular}


Location

Alameda

State, Prov.

Saskatchewan

\section{Lat( $\left({ }^{\circ} \mathbf{N}\right)$}

49.27

Lon

ng $\left({ }^{\circ} \mathrm{W}\right)$

102.28

MMI

III
A number of local people felt the disturbance but did not know at the time of the occurrence that an earthquake had taken place. (Alameda Dispatch, May 21, 1909)

Alexande

Manitoba

49.83

100.33

IV

It was sufficient to cause a very slight motion to buildings (Winnipeg Tribune, May 17, 1909)

Battleford

Saskatchewan

52.74

108.31

IV

Billings

Montana

45.78

108.50

III

Dishes rattled and houses shook but no damage was done. (Battleford Saskatchewan Herald, May 22, 1909)

Bismarck

North Dakota

46.80

100.78

IV

For several seconds there was a distinct vibration, sufficiently distinct to be felt inside houses, and to cause a sort of trembling of floors and walls. Dishes were rattled on the shelves and furniture shaken, and doors and walls quivered as they might in a heavy wind. (Bismarck Daily Tribune, May 18, 1909, p. 4)

Brandon

Manitoba

49.83

99.95

IV

People in their homes felt most distinct tremors, which caused windows, doors and other loose furniture to rattle. (Regina The West, May 19, 1909); In many houses articles of furniture were observed to move, and some residents were even badly scared. (Brandon Weekly Sun, May 20, 1909)
102.43

Saskatchewan

51.64

49.87

99.36
Canora

Carberry

Manitoba
IV

Walls cracked and window blinds swayed perceptibly, dishes, window panes and doors rattled and a rumbling noise was heard. (Canora Advertiser, May 20, 1909)

III The shaking was much more evident to those who chanced to be upstairs at the time ... At first it was thought by many that it was a heavy freight train passing through town (Carberry Express, May 20, 1909); Those who were upstairs and especially those who had retired felt the shock most distinctly, may wondered what had happened. (Carberry News, May 21, 1909)

Chinook

Montana

48.59

We experienced the same earthquake shock about nine
109.23
IV-V o'clock, the first ever felt in this vicinity. No serious damage was done here. The breaking of a few dishes and a good scare for everyone was the extent of the damage (Glasgow Democrat, May 20, 1909). The tremor was quite distinct and made practically every building in town quiver, rattling dishes on the shelves and shaking lamps on the tables. Most people rushed out of doors to see what had happened. The shock was a very short one, only lasting about ten seconds. The movement was gradual and light at first, culminating the last few seconds in quite intense tremors. Chickens and animals were badly frightened and ran wildly about (Chinook Opinion, Chinook, Choteau County, Montana, Thursday, May 20, 1909). 
Location

Choteau

Craik

Creelman

Culbertson

Cupar

Cut Bank

Dauphin

Manitoba

51.15

100.05

IV

50.68

47.80

112.17

$105.81 \quad$ IV

49.82

103.32

50.95

104.21 IV
MMI

III

Source

Some of the people in Choteau Saturday evening felt a slight earthquake tremor at about half past nine. A great many thought that it was a sudden gust of wind; others, however, pronounced it a slight quake, and they were verified by reports that came in from surrounding points (Choteau Acantha, May 20, 1909).

Buildings rocked and swayed and in many cases the inmates rushed into the street in great alarm.(Craik Weekly News, May 20, 1909)

V

Several small articles were dislodged in the station house. (Winnipeg Tribune, May 17, 1909)

104.52 V-VI .the shock was felt by everyone who was inside a building. Those who were on the street did not feel it. The Evans hotel and Courchene building both of which are brick structures were shaken. Vases and other fragile things were shaken off shelves and other resting places and broken. There seemed to be three distinct shocks which lasted in all about 15 seconds (Glasgow Democrat, May 20, 1909).

Citizens of Culbertson were startled Saturday evening. May 15th, about 9:10 o'clock by feeling a distinct trembling of the earth which lasted several seconds. Dishes rattled, lamp chimneys fell off, houses creaked and some people were affected with nausea (Culbertson Searchlight; May 21, 1909 page 1.). H.G. Walsh and Ralph Bush, who room on the third floor of the Reed Cash Grocery, say that the vibration was so great that a lamp chimney fell off the lamp, and that a small pen knife which was lying near the edge of a table was shaken to the floor (Culbertson Republican, Friday May 21, 1909).

kettles, furniture, etc. started dancing (Cupar Herald \& North Q'Appelle Chronicle, May 19, 1909)

Not Felt Cut Bank, May 17.-We did not feel anything here at cut Bank, and now west of here to my knowledge. R.C. Rasmussen.(Glasgow Democrat, May 20, 1909)

those who still lingered in the highways and byways, were among those regretful ones who remained unshocked ... a number of people rushed into the street ... In many of the houses and stores dishes and bottles rattled on the shelves, but only in one case was anything reported as having fallen, and that occurred in one of the stores, though above the Herald office some of the ceiling plaster was dislodged. (Dauphin Herald, May 20, 1909); particularly noticeable by people who were in the upper flats of their houses. Those on the streets were not aware of anything unusual happening. (Dauphin Press, May 20, 1909) shaking the windows an
Tribune, May 17, 1909) 
Location

Deloraine

North Dakota

46.87

102.78

IV

train dispatchers in the new Northern Pacific depot were frightened from their telegraph instruments and ran out of the building. They were prevented from returning to their keys for some time owing to the falling of a wall which succumbed and crashed in like an egg-shell (Glasgow Democrat, Thursday, 20 May 1909, p. 5). Dishes rattled, houses shook and many were frightened (Dickinson Press, May 22, 1909).

Disley

Saskatchewan

50.64

105.06

IV

Dishes rattled and the earth vibrated to an extent that made walking difficult (Regina Morning Leader, May 17, 1909)

Elgin

Manitoba

49.43

100.27

IV

Doors not tightly closed were jarred open and household fixtures generally were visibly shaken. (Winnipeg Telegram, May 17, 1909)
Estevan

Fargo

Forsyth
Saskatchewan

49.15

102.98

IV felt by everyone here, ... no single person appears to have thought at the time that it could be an earthquake that shook the houses and made the dishes rattle.... In T.M. Perry's hardware store the stoves and tins rattled, ... The Empire Hotel, a solid brick building was shaken visibly, the chandeliers swaying and glasses rattled. (Regina Morning Leader, May 17, 1909)

96.78

III

Although the shock was very slight and was probably mistaken for some other cause by a great many people, yet the fact that citizens in all parts of the town are unanimous in stating that they felt a shock or slight trembling of the earth at about 9 o'clock Saturday evening, proves that it was the trembling of the earth (The Fargo Forum and Daily Republican, Fargo, N.D., Monday Evening, May 17, 1909, page 8).

$46.27 \quad 106.68$

106.68
III
Montana
A few Forsythians, who noted the disturbance, say that it lasted but a few seconds, and had a slight rocking motion, similar to the jar caused by a heavy vehicle in passing (Forsyth Times, Thursday May 20, 1909). 
Table 3. MMI assignments, May 16, 1909, earthquake

Location

Fort Benton

State, Prov.

Montana

47.82

(1)

Lor

ong ( $\left.{ }^{\circ} \mathbf{W}\right)$

MMI

IV

caused a tremor throughout many business and residence buildings, and the occupants were at first puzzled to account for the peculiar vibration. Pictures hanging on the wall were swung out of position, and dishes and glassware rang in faint alarm as the quake jingled them together. There was no damage of any kind in this vicinity; it was simply a novel and not altogether a pleasant experience (River Press Weekly, Fort Benton, Wednesday May 19, 1909).

Fort Williams

Saskatchewan

Glasgow

Montana

48.18

106.63

52.11

106.66 Not Felt Fort here or at Port Arthur Saturday night.(Winnipeg, Telegram, May 17,1909$)$

$106.63 \quad V-V I$

..attributed it to the passing of a heavy freight train through the railroad yards.. ..the paper on the walls commenced to crack and pull away then it was that men, women and children fled from the buildings and sought shelter in the open streets. At the residence of Mr. James Flaherty, living a short distance in the country, the paper was torn from the ceiling; a pile of brick near the Great Northern tracks was thrown to the ground; the clock in the office of attorneys Hurd and Lewis stopped at 16 minutes past nine; in a number of homes dishes were shaken to the floor and pictures on the walls swayed back and forth (Glasgow Democrat, Thursday, 20 May 1909, p. 5). Last Saturday night about 9:20 o'clock, the whole town was thrown into excitement by two earthquake shocks. The first was quite light and many did not notice it, but the second was very pronounced and lasted about 10 or 12 seconds. During the night, about eleven o'clock and five the next morning, two other light trembles were felt (Valley County News; Glasgow, Montana, Friday May 21, 1909).

At Glendive the shock was very pronounced, it being felt at 9:16 and continued for 18 seconds. The Masons were holding a meeting in Masonic Temple at the time, and when the building commenced to rock the members rushed to the streets fearing the building would collapse (Glasgow Democrat, Thursday, 20 May 1909, p. 5). At Great Falls, Havre, Wagner, Choteau, Glendive and other cities in the eastern and northern parts of the state the shock was felt and dishes were tumbled from the shelves (Culbertson Searchlight; May 21, 1909 page 1. Later reports from different parts of Glendive also tell of dishes thrown down and broken (Fargo Forum and Daily Republican, May 17, 1909). 
Location

Great Falls

State, Prov.

Montana

47.50

111.30

MMI

-VI

At Great Falls the shock was felt for several seconds, no serious damage was done. The earth's disturbance was violent enough to throw dishes from the shelves and pictures from the walls, and to cause the inhabitants to flee to the open streets (Glasgow Democrat, Thursday, 20 May 1909, p. 5). At Great Falls, Havre, Wagner, Choteau, Glendive and other cities in the eastern and northern parts of the state the shock was felt and dishes were tumbled from the shelves (Culbertson Searchlight; May 21, 1909 page 1). From Great Falls, Mont., it is reported that the earthquake shock was felt there for several seconds. While no serious damage was caused, the shock was of sufficient violence to throw things from the shelves and to cause the people to rush pell mell into the streets (Culbertson Searchlight; May 21, 1909 page 4).

Grenfell

Saskatchewan

50.40

102.93

V-VI

the shock was so severe that horses traveling on the road had difficulty keeping their feet (Brandon Weekly Sun, May 20, 1909)

\section{Halbrite}

Saskatchewan

49.50

103.57

IV

The walls shook and the dishes rattled on the shelves (Winnipeg Tribune, May 17, 1909)

Harlem

Montana

48.53

108.78

IV

Residents of Harlem felt the shock at about 9:15 and lasted but a few seconds. In some homes dishes were rattled and windows shaked [sic] but nowhere in this vicinity was any damage done. Those who were outside felt no shock (The Harlem News, Harlem, Montana, Thursday, May 20, 1909).

Harlowton

Montana

46.44

109.84

III

The shock was quite perceptible in many of the larger buildings. It came about 9:15 and the tremor was sufficient to attract general attention, although few understand the cause. Those who were indoors could notice the vibrations distinctly. Water in glasses could be seen to tremble, and electric light globes were set swinging. Many attributed the disturbance to the wind (The Harlowton News, Harlowton, Meagher County, Montana, Friday May 21, 1906).

Hartney

Manitoba

49.48

100.52

VI

glasses in the hotels were shaken off the bars and broken (Winnipeg Tribune, May 17, 1909)

Havre

Montana

48.55

109.68

At Great Falls, Havre, Wagner, Choteau, Glendive and other cities in the eastern and northern parts of the state the shock was felt and dishes were tumbled from the shelves (Culbertson Searchlight; May 21, 1909 page 1. The quake was sufficient to rattle dishes upon the table and make the incandescent bulbs dance weirdly. Buildings all over the city quaked and in the Hotel Havre a number of people sought the street and they stood not upon the order of their going. A few of the early to bed patrons hustled out in their pajamas and nighties, [sic] and the exodus at the hotel was not unlike that in other building blocks in the city. ..felt not unlike a bridge vibrating with a heavy load passing over it, the team on a trot. The shock in Havre lasted probably five seconds, and did absolutely no damage. (Havre Plaindealer, Havre, Montana, Saturday, May 22, 1909). 
Location

Helena

State, Prov.

Montana

Montana

48.39

107.09

46.58

46.58

112.03

MMI

IV
their homes into the streets in wild bewilderment
momentarily expecting to see their dwellings razed to the
ground; but the only serious damage done so far reported the Capital City was the falling down of a retaining wall ten feet height and two feet in thickness, and the shifting of a house to a considerable extent. Some idea of the force of the shock may be imagined when it is stated that the wall that fell was built of brick and heavy masonary [sic] and was intended to with-stand great pressure (Glasgow Democrat, Thursday, 20 May 1909, p. 5). more distinctly felt in the eastern and southern portions of the city and a retaining wall at the residence of Herman Paul at five hundred and ten South Rodney street was hurled down. The wall was ten feet high and two feet thick (Culbertson Searchlight; May 21, 1909 page 1). In Helena furniture and dishes were rattled and walls were shaken down (The Helena Independent).

\begin{tabular}{|c|c|c|c|c|c|}
\hline Hinsdale & Montana & 48.39 & 107.09 & IV & $\begin{array}{l}\text { At Hinsdale the quake lasted about } 3 \text { seconds and was } \\
\text { severe enough to cause most all the people to leave their } \\
\text { buildings, and those who had retired for the night were } \\
\text { shaken so that they got out of bed. In the business portion of } \\
\text { the town people ran into the street expecting other shakes to } \\
\text { follow (Montana Homestead, Hinsdale, Valley County, } \\
\text { Montana, Friday May 21,1909). }\end{array}$ \\
\hline Indian Head & Saskatchewan & 50.53 & 103.68 & VI & $\begin{array}{l}\text { sufficiently severe to move the content of houses and stores. } \\
\text { The buildings moved perceptibly.(Moose Jaw Evening } \\
\text { News, May 17, 1909); , where windows rattled and heavy } \\
\text { articles such as stoves and furniture where moved. } \\
\text { (Saskatton Daily Phoenix, May 17, 1909); goods were } \\
\text { shaken from the shelves in stores, furniture and lamps, and } \\
\text { dishes in houses were moved and the citizens rushed to the } \\
\text { open (Carman Standard, May 27, 1909) }\end{array}$ \\
\hline Invermay & Saskatchewan & 51.78 & 103.15 & IV & $\begin{array}{l}\text { Dishes on the sideboards rattled (Winnipeg Tribune, May } \\
17,1909 \text { ) }\end{array}$ \\
\hline Kamsack & Saskatchewan & 51.57 & 101.85 & III-IV & $\begin{array}{l}\text { in some houses the windows rattled. (Kamsack Times, May } \\
21,1909 \text { ) }\end{array}$ \\
\hline Kennedy & Saskatchewan & 50.01 & 102.35 & IV & $\begin{array}{l}\text { Several houses and stores were shaken and furniture, lamps, } \\
\text { etc., swayed considerably, startling the residents. (Manitoba } \\
\text { Free Press, May } 18 \text { 1909); Furniture, lamps, etc., swayed } \\
\text { considerably, startling the residents. (Winnipeg Telegram, } \\
\text { May 18, 1909) }\end{array}$ \\
\hline Langham & Saskatchewan & 50.15 & 101.67 & IV & $\begin{array}{l}\text { Houses rocked and their contents rattled. (Regina Morning } \\
\text { Leader, May 17, 1909) }\end{array}$ \\
\hline
\end{tabular}


Location

Lanigan

Lead

South Dakota

44.35

103.75

Lethbridge

Alberta

Lewistown

Montana

109.42 III

112.80

III-IV (Winnipeg Tribune, May 17, 1909) place distinctly felt the earthquake shocks on last Saturday evening at 9:15 o'clock, the time the quake was felt in Montana (The Northwest Post; Belle Fourche, South Dakota; May 20, 1909). Emil Faust and one or two other reliable and trustworthy citizens declare that at that hour two distinct shocks of earthquake took place, sufficient in their intensity to knock down small articles from the shelves and to make things generally move in the rooms in which they were sitting (Daily Pioneer Times, Deadwood, SD, May 18, 1909).

Lewistown and other points in Fergus County experienced slight shocks (Havre Plain Dealer, May 22, 1909); The next day brought reports from Great Falls and Lewistown that buildings there had been shaken (The Harlowton News, May 21, 1909)

Lloydminster

Saskatchewan

110.01 Not Felt

loydminster, Sask., May 16 - No earthquake was felt here last night. (Winnipeg, Telegram, May 17, 1909)

Lumsden

Saskatchewan

50.65

104.87

IV

to rattle crockery $\ldots$ and ...... furniture Morning Leader, May 17, 1909)

98.80 III-IV

49.95

a shock supposed to have been caused by an earthquake was felt in the town (Winnipeg Tribune, May 17 1909)

Malta

Montana

48.35

107.87
Malta and vicinity experienced a slight earthquake shock at 9:20. Saturday evening, the seismic disturbance was from north to south. Some buildings were shaken, causing dishes to fall from shelves, but no damage is so far reported. Many people were badly frightened, imagining the millenium had come (Glasgow Democrat, May 20,1909). Saturday night at 9:15 this vicinity was visited by an earthquake shock. Houses shook and windows and dishes rattled but no serious damage was done (Valley County News; Glasgow, Montana, Friday May 21, 1909). It lasted about thirty seconds. However, no damage was caused by the shock, although windows rattled as thought a strong wind was blowing. Dishes in some of the lighter homes were rattled from their accustomed places (Great Falls Daily Tribune, Great Falls, Montana, Sunday Morning May 16, 1909). 
Location

Maple Creek

McTaggert

Medicine Hat

Melfort

Miles City

Milestone

Minto

Mondak

Montana

48.02

104.05

$49.92-109.47$

49.73

104.01

110.68

North Dakota

46.91

103.52

104.63
MMI

IV

IV

The vibrations were not sufficient enough to cause any damage but considerable fright was created (Winnipeg Tribune, May 17, 1909)

making dishes rattle, chandeliers swing,... Nearly every store in town was vacated by customers and clerks alike, the swaying of the buildings and the swinging to and fro of suspended articles.... People walking along the sidewalks apparently never felt the shock. (Maple Creek News, May 20, 1909)

crockery rattled (Winnipeg Tribune, May 17 1909)

IV

A slight earthquake shock was felt here Saturday evening about 9 o'clock. Dishes in cupboards rattled and pictures on the walls were disturbed. There were two distinct shocks, at slight intervals and were very noticeable (Fargo Forum and Daily Republican, May 17, 1909).

IV

A slight earthquake shock was felt here (Winnipeg Tribune, May 17, 1909)

..not felt in street, scarcely perceptible on the first floor dwellings, and had to be supported by collaborators evidence by person on second floors before they were sure it was not their imagination. Dishes rattled and in some houses furniture moved around like in a spiritual scene (Miles City: Daily Yellowstone Journal and Miles City: Stockgrowers Journal - Monday May 17, 1909).

Buildings were jarred slightly and in the hardware stores the tea-pots and tinware rattled considerably. (Milestone Mail, May 21, 1909)

100.00

III

Hugh McMillan was struck with the vibration of his house, something he never experienced before, but paid no attention to it, while R.O. Morrow heard a noise resembling a rig passing over the bridge near his place. (Minto Packet, May 20, 1909); Very few recognized the earthquake on Saturday evening, (Minto Riverside Review, May 22, 1909)

IV-V Saturday evening at 9:15 there was a good deal of excitement in our little city when people discovered that dishes were rattling and tables moving without any apparent cause. The earthquake shock lasted for about 30 seconds and was quite severe in places but no damage was done in the city (Mondak Montana, Saturday, May 22, 1909).

Not Felt Montreal, Que., May 17 - No trace of an earthquake shock was felt here. (Brandon Weekly Sun May 20,1909) 


\section{Location}

Moose Jaw
State, Prov.

Saskatchewan

Saskatchewan

Manitoba

49.19

Morden

Neepawa

Manitoba

50.23

99.47

Saskatchewan

50.73

103.03

Port Arthur

Saskatchewan

Portage la Prairie

Manitoba

Prince Albert

Saskatchewan

53.25

105.75

98.33
50.55

103.90
III

\section{Review, May 19, 1909)}

III Saturday, May 22, 1909); People living in brick houses never noticed it at all, but some who happened to be upstairs in brick houses felt a slight movement of the building. (Regina Morning Leader, May 17, 1909)

\section{Source}

At Moosejaw walls were shaken to such an extent that there is hardly a house in the city in which the pictures were not thrown to the floor (Glasgow Democrat, Thursday, 20 May sufficient to shake articles off mantles (Yellowstone onitor, Glendive, MT, Thursday May 20, 1909, page 1). in some cases it is reported that plaster was cracked and pictures fell. ... desks commenced to display a tendency to take a walk across the floor. ... On the other hand the Moose Jaw Evening Times, May 17, 1909) where dishes were rattled and lamps set swinging. (Regina The West, May 19, 1909) $20,1909)$; In some instances the dishes on the sideboard shelves were heard to rattle, (Morden Empire, May 20, 1909) house swayed to and fro quite perceptibly. (Neepawa Register, May 20, 1909)

causing windows to rattle. (Winnipeg Tribune, May 17 1909)

Not Felt Fort Williams, May 16 - No earthquake shock was felt here or at Port Arthur Saturday night. (Winnipeg, Telegram, May 17, 1909)

Houses swayed, doors rattled, crockery and plaster fell (Qu'Appelle Progress, May 20, 1909); the ground and buildings swayed with a gentle undulating motion (Regina The West, May 19, 1909) 
Location

Rapid City

State, Prov.

South Dakota

Lat $\left({ }^{\circ} \mathbf{N}\right)$ Long $\left({ }^{\circ} \mathbf{W}\right)$

44.07

103.22

MMI

III-IV Rapid City and vicinity felt a perceptible seismic disturbance Saturday evening at 9 o'clock and there were many persons who believed that the city was about to experience an earthquake. In several instances brick buildings standing alone trembled and frightened the occupants to such an extent that they fled in fear that the structures would fall (Rapid City Daily Journal; Rapid City, South Dakota, Sunday morning, May 16, 1909).

104.63

On the ground floor of a house it was hardly perceptible, differing little from the vibration caused by trains shunting or a wagon driven swiftly over the pavement. (Regina Daily Standard, May 17, 1909); Pictures moved on the walls, electric lights flickered and many other results were noticed. ... at first thought to be only the passing of a heavy vehicle, or a train, in some cases it was thought that an explosion had occurred. ... After the shock had subsided many experiences were greatly exaggerated. (Regina the West, May, 19, 1909)

Books were almost shaken from the bookcase... Furniture, dishes, and even pianos rocked considerably in many houses. (Saskatoon Daily Phoenix, May 17, 1909); Articles inside of the buildings moved around considerably, even pianos worked. Several people in the downtown district rushed from the buildings badly frightened. (Regina Morning Leader, May 17, 1909); Articles inside buildings moved around considerably, even to pianos. Several people in downtown districts rushed from buildings badly frightened. (Brandon Weekly Sun, May 20, 1909)

Saco

Montana

48.45

107.33

IV

An earthquake struck here at 9:15 p.m., shaking all buildings quite badly but no damage was done. There were two waves, the first one light, followed closely by a second one which was heavier, lasting eight or nine seconds. The first shock shook buildings like a heavy wind (Great Falls Daily Tribune, Great Falls, Montana, Sunday Morning May 16, 1909).

Buildings rocked, doors creaked, dishes rattled and the earth trembled (Regina the West, May 19, 1909); In scores of homes windows rattled, doors shook, pictures swayed on the walls and dishes and glassware clinked and clattered restlessly ...creaking and rattling of doors and windows (Saskatoon Daily Phoenix, May 17, 1909)

Selkirk

Manitoba

50.17

96.87

III

Windows rattled (Selkirk Expositor, May 21, 1909); 
Location

Strasbourg

Manitoba

52.10

101.27

MMI

Saskatchewan

Swift Current

Saskatchewan

50.28

107.82

III

Swift Current and Lanigan in that province, about five hundred miles west of Winnipeg, have been [heard?] from and declare that the tremors there lasted for fully ten seconds (Glasgow Democrat, Thursday, 20 May 1909, p. 5).

Terry

Montana

46.79

105.31

III

It came along gently about 9:30 and made those who retired feel like the timid woman who always had to look for a man under the bed. The sensation was as if someone was under the bed trying to lift it (Terry Tribune - Friday, May 21, 1909).

Theodore

Saskatchewan

51.43

102.97

IV

Windows rattled (Winnipeg Tribune, May 17 1909)

British Columbia

123.11 Not Felt Vancouver, May 17 - No earthquake occurred here. (Winnipeg, Telegram, May 18, 1909)

Virden

Manitoba

49.83

100.95

III

the passing in close proximity of some very heavy load. When the former was suggested the next morning by some who felt the disturbance they were ridiculed but reports substantiate their suggestion. (Virden Empire Advance, May 20, 1909)

Wagner

Montana

48.37

108.07

IV-V other cities in the eastern and northern parts of the state the shock was felt and dishes were tumbled from the shelves (Culbertson Searchlight; May 21, 1909 page 1.) At Wagner, Choteau county, the disturbance is reported to have lasted 30 seconds, and appeared to run from north to south (Yellowstone Monitor, Glendive, MT, Thursday May 20,1909, page 1). A distinct earthquake shock occurred here at 9:16 this evening, buildings rocked; and the low, rumbling sound suggested the passing of a train. The disturbance seemed to run from north to south, and was of about 30 seconds' duration (Great Falls Daily Tribune, Great Falls, Montana, Sunday Morning May 16, 1909). tables and floor swayed in a manner to be disagreeable to the operators at work. ... Hundreds of people, who noticed the slight shaking of their houses, put it down to the jarring of the street cars or gave the matter no attention. It was not until morning, in many cases, that they learned the real cause. (Winnipeg Telegram, May 17, 1909); 
Location

Watrous

Wellwood

Weyburn

Whitewood

Saskatchewan

50.33

102.26

III

Saskatchewan

50.15

Wilcox

Manitoba

North Dakota

48.13

103.63

III

A great many of our citizens were alarmed Saturday night when a slight earthquake shock was felt. Parties in dwelling houses and those living upstairs in the flats in the business portion of the city noticed more of a shock than others (Williston Graphic, Williston, Williams County, N.D., Thursday, May 20, 1909).

An Associated Press dispatch from Winnipeg dated Saturday night says: Earthquake shocks which seem to have followed a general movement from north to south and west were felt here at 10:17 o'clock tonight. They came in quick succession and lasted fully twenty seconds. People rushed from their homes and remained on the streets until all apparent danger had passed (Glasgow Democrat, Thursday, 20 May 1909, p. 5). comparatively few people noticed anything unusual and no one, as far as can be learned, felt the shock when in the street. In Winnipeg the shock appeared to travel north to south and lasted about forty seconds. No damage was done to property and a number of people failed to notice the tremor. (Saskatoon Daily Phoenix, May 17, 1909);

Wolseley

Saskatchewan

50.42

103.28

IV pictures on walls, or articles hung up in the stores swung to and from ... Those walking on the streets did not seems to notice the shock, while those indoors, with very few exceptions, were more or less disturbed. ... the well caved in fully an hour before the quake was felt (Wolseley News, May 20, 1909); goods hanging from ceilings were seen moving for a couple of seconds (Regina the West, May 19, 1909) 


\section{Table 3. MMI assignments, May 16, 1909, earthquake}

Location

Yorkton

State, Prov.

Saskatchewan

Montana

47.92

108.53

51.20

(1)

ong $\left({ }^{\circ} \mathbf{W}\right)$
MMI

IV-V

\section{Source}

So unmistakable was it that everyone notices it... It seemed to be travelling from west to east from the fact that furniture, doors, etc., on the west side of buildings were seen to shake before those on the east side. (Regina the West, May 19, 1909) ; Furniture and crockery were badly shaken in some houses... traveling from west to east as things shaken swaying in these directions. ... A great many people did not notice it at all (Yorkton Enterprise, May 22, 1909)

(1)

A message from Zortman, in the Little Rockies states that the shock was felt strongly there but no damage reported (The Harlowton News, Harlowton, Meagher County, Montana, Friday May 21, 1906). building were considerably rocked by waves extending over a period of one minute (Zortman - Little Rockies Miner). 
Table 4. Comparison of MMI assignments, May 16, 1909, earthquake

\begin{tabular}{|c|c|c|c|c|}
\hline Place & State/Prov. & Nuttli $\mathrm{MMI}^{\dagger}$ & BSR MMI $\$$ & $\begin{array}{r}\text { Nuttli MMI - } \\
\text { BSR MMI }\end{array}$ \\
\hline Alexander & Manitoba & IV & IV & 0.0 \\
\hline Bismarck & North Dakota & III & IV & -1.0 \\
\hline Brandon & Manitoba & V & IV & 1.0 \\
\hline Choteau & Montana & III-IV & III & 0.5 \\
\hline Creelman & Saskatchewan & $\mathrm{V}$ & $\mathrm{V}$ & 0.0 \\
\hline Debuc & Saskatchewan & IV-V & IV & 0.5 \\
\hline Deloriane & Manitoba & IV-V & IV & 0.5 \\
\hline Dickinson & North Dakota & IV & IV & 0.0 \\
\hline Elgin & Manitoba & IV-V & IV & 0.5 \\
\hline Estevan & Saskatchewan & IV-V & IV & 0.5 \\
\hline Fargo & North Dakota & III & III & 0.0 \\
\hline Glasgow & Montana & V & V-VI & -0.5 \\
\hline Glendive & Montana & V & V-VI & -0.5 \\
\hline Great Falls & Montana & IV & V-VI & -1.5 \\
\hline Grenfell & Saskatchewan & V-VI & V-VI & 0.0 \\
\hline Halbrite & Saskatchewan & IV-V & IV & 0.5 \\
\hline Havre & Montana & IV & IV & 0.0 \\
\hline Helena & Montana & IV & IV & 0.0 \\
\hline Indian Head & Saskatchewan & VI & VI & 0.0 \\
\hline Invermay & Saskatchewan & IV & IV & 0.0 \\
\hline Kamsack & Saskatchewan & V & III-IV & 1.5 \\
\hline Lethbridge & Alberta & III-IV & III-IV & 0.0 \\
\hline Lewistown & Montana & III & III & 0.0 \\
\hline Macgregor & Manitoba & III-IV & III-IV & 0.0 \\
\hline Malta & Montana & IV & V-VI & -1.5 \\
\hline Maple Creek & Saskatchewan & IV-V & IV & 0.5 \\
\hline McTaggert & Saskatchewan & V & IV & 1.0 \\
\hline Medicine Hat & Alberta & IV & IV & 0.0 \\
\hline Melfort & Saskatchewan & IV & IV & 0.0 \\
\hline Minto & Saskatchewan & III & III & 0.0 \\
\hline Moose Jaw & Saskatchewan & $\mathrm{V}-\mathrm{VI}$ & $\mathrm{V}-\mathrm{VI}$ & 0.0 \\
\hline Moosomin & Saskatchewan & IV & IV & 0.0 \\
\hline Neudurf & Saskatchewan & V & V & 0.0 \\
\hline Portage la Prairie & Manitoba & III & III & 0.0 \\
\hline Prince Albert & Saskatchewan & III & III & 0.0 \\
\hline Qu Appelle & Saskatchewan & V-IV (?) & IV-V & \\
\hline Regina & Saskatchewan & IV-V & III-IV & 1.0 \\
\hline Rosenthern & Saskatchewan & V & V & 0.0 \\
\hline Saco & Montana & IV & IV & 0.0 \\
\hline Saskatoon & Saskatchewan & IV & IV & 0.0 \\
\hline Selkirk & Manitoba & III & III & 0.0 \\
\hline Swift Current & Saskatchewan & IV & III & 1.0 \\
\hline Theodore & Saskatchewan & IV & IV & 0.0 \\
\hline Virden & Manitoba & III & III & 0.0 \\
\hline Wagner & Montana & IV & IV-V & -0.5 \\
\hline Waskada & Manitoba & V & IV & 1.0 \\
\hline Weyburn & Saskatchewan & VI & $\mathrm{V}-\mathrm{VI}$ & 0.5 \\
\hline
\end{tabular}


Table 4. Comparison of MMI assignments, May 16, 1909, earthquake

\begin{tabular}{llccr} 
Place & State/Prov. & Nuttli MMI $^{\dagger}$ & BSR $_{\text {MMI }}$ § & $\begin{array}{r}\text { Nuttli MMI - } \\
\text { BSR MMI }\end{array}$ \\
\hline Wilcox & Saskatchewan & V & IV & 1.0 \\
Winnipeg & Manitoba & III-IV & III-IV & 0.0 \\
Yorkton & Saskatchewan & V & IV-V & 0.5 \\
\hline
\end{tabular}

${ }^{\dagger}$ Taken from Nuttli's (1976) isoseismal map (fig. 1).

§From table 3 . 


\section{Appendix A. Newspaper accounts from U.S. archives (Key phrases for Modified Mercalli Intensity assignments are underlined)}

Aberdeen Daily American; Aberdeen, South Dakota; Saturday May 16, 1909; page 1

EARTHQUAKE IN MONTANA

Earth Tremor Felt in Neighboring State Severe Enough to Clear Shelves

HOUSE WALL TWO FEET THICK IS THROWN DOWN

Motion of Earth's Crust Felt Generally Through Canada North of Here

Great Falls, Mont., May 15. - An earthquake shock was felt here tonight. It was also felt at Choteau, Havre, Wagner and other points, showing that it prevailed generally over northern Montana. While no serious damage was done the shock was sufficient to throw things from shelves.

Winnipeg, May 15. - Somewhat severe earth tremor was felt in Winipeg at 10:17 lasting about 20 seconds. The movement of the earth was from north to south. It was also felt at Swift Current, Saskatchewan and Lanigan, Saskatchewan, 500 miles west.

Helena, Mont., May 15. - At 9:15 p.m. an earthquake shock lasting several seconds was felt. The only damage reported is that of a residence in which a 40-feet [sic] front wall was thrown down. The wall was ten feet high and two feet through.

The Northwest Post; Belle Fourche, South Dakota; May 20, 1909

The Lead Call states that quite a number of citizens of that place distinctly felt the earthquake shocks on last Saturday evening at 9:15 o'clock, the time the quake was felt in Montana.

Local Briefs

\section{Belt Valley Times, Thursday May 20, 1909}

The earthquake shock which was felt here Saturday evening at 9:15 was the general subject of talk in the city the next day. Nearly everyone in the city felt two distinct shocks of several seconds duration. No damage resulted and from newspaper report the shocks were felt throughout the sate and parts of Dakota and Canada.

The Billings Daily Gazette, Sunday, May 16, 1909

MONTANA VISITED BY SEVERE EARTHQUAKE SHOCK LAST NIGHT

Wall Two Feet Thick Thrown Down by Force of Shock at Helena-Disturbance General in Northern Montana.

(SPECIAL TO THE GAZETTE)

HELENA, May 15,-At 9:15 o'clock tonight an earthquake shock lasting several seconds was felt here. A number of people have reported that their houses were distinctly shaken and that dishes and furniture rattled. The only damage reported is that at the residence of Herman Paul, No. 510 Rodney street, the front retaining wall of the house being thrown down by the shock.

The wall was 10 feet high and two feet thick.

Shocks have also been reported from Glendive, Great Falls, Havre and other towns in the northern part of the state.

GREAT FALLS, May 15,-A distinct earthquake shock was felt here this evening at 9:14 o'clock and it also was felt at Choteau, Havre, Wagner and other points at the same time, showing that it prevailed generally over northern Montana. While no serious damage was done the shock was sufficient to throw things from shelves in stores and there was some breakage of glassware.

BUTTE, May 15,-A Miner Special from Glendive says.

At 9:16 this evening Glendive felt a very perceptible seismic disturbance. It seemed to be worse in some portions of the city than I others. A number of men gathered in the Masonic temple rushed from the building believing it was about to fall. In many houses dishes rattled in the pantries. The first shock lasted probably 2 or 3 seconds with unusually rapid vibrations. At first it was thought a heavy wind was approaching. According to telephone reports received here the disturbance was of wide extent. It was felt at Forsyth east of here, and at Dickinson, N.D. where it is reported to have been very severe. 
Later reports received by train dispatchers here indicate that the strongest disturbance extended from here to Dickinson, N.D., east of that point being very light. The dispatchers in the new Dickinson depot were frightened from their posts.

The Town of Glasgow on the Great Northern was badly shaken. Reports from different parts of Glendive also tell of dishes thrown and broken. So far, the Northern Pacific tracks have not suffered. The operator at Freyburg, N.D. says his quarters felt the shock.

SHOCK AT WINNIPEG.

WINNIPEG, Man., May 15,- - A somewhat severe earthquake was felt in Winnipeg tonight at 10:17 o'clock lasting about 230 seconds. The movement was from north to south. The shock was also felt at Swift Current Sask. and at Lanigan, 500 miles west.

Reports from Weyburn and Moose Jaw state that the tremor was sufficient to shake articles off mantles. It seemed to have been felt between Moose Jaw and this city as far north as the Saskatchewan river, 30 points having been reported up to midnight.

\section{The Billings Daily Gazette, Wednesday, May 19, 1909}

\section{FELT SHOCK OF THE RECENT EARTHQUAKE}

But Two Billings People Claim That Seismic Disturbance Was Apparent Here.

Not to be outdone by the other cities of the state, here are Billings people who claim that the earthquake shock of last Saturday evening was felt in this city, as well as in Glendive and Helena. I.D. O'Donnell says that he was sitting in a chair at the time of the shock and that he distinctly felt the tremor of the earth. He says that his home on Clark avenue was visibly shaken by the quake, but that at the time he credited the shake to a freight engine which was wrestling with a number of cards in the yards.

S.W. Soule has confessed that he was also at home reading at the time of the quake, which was about 9:15 in the evening, and that a door which heretofore has never been in the habit of opening by itself, swung open. Mr. Soule arose, anticipating the entrance of a visitor, but no one entered. He was puzzled about that open door until the next morning when he read the accounts of the earthquake.

\section{Bismarck Daily Tribune, Bismarck, North Dakota, Sunday Morning, May 16, 1909 (Page 1) EARTHQUAKE SHOCKS FELT IN THE WEST}

$$
\text { (By Associated Press.) }
$$

Great Falls, Mont., May 15.-Earthquake shocks was felt [sic] here tonight. It was also felt at Choteau, Havre, Wagner and other points, showing that it prevailed generally over Northern Montana. While no serious damage was done the shock was sufficient to throw things from shelves.

Winnipeg, Man., May 15.- Somewhat of an earth tremor was felt in Washington at 11:17 lasting two seconds. Moving from north to south. Also felt at Swift Current, Sask., and Lanigan, Sask., five hundred miles west.

Helena, Mont., May 15.-At 9:15 o'clock tonight an earthquake shock lasting several seconds was felt. The only damage reported is of a residence, where the front wall was thrown down. The wall was ten feet high and two feet thick.

\section{Bismarck Daily Tribune, Bismarck, North Dakota, Tuesday Morning, May 18, 1909 (Page 4)} SEISMIC DISTURBANCE IS FELT IN BISMARCK DISTINCT VIBRATION LASTING FOR SEVERAL SECONDS SATURDAY.

Tremor Strong in Western Paht [sic] of State-Dishes Rattled on Shelves and Furniture Shaken.

Bismarck people became aware Sunday, upon learning of the distinct earthquakes shocks in Montana and other comparatively nearby points, that they had passed through a slight earthquake shock the previous night between 9 and 10 o'clock, without being aware of it.

For several seconds there was a distinct vibration, sufficiently distinct to be felt inside houses, and to cause a sort of trembling of floors and walls. In some cases householders went down into their basements to see if there were furnace explosions of gas, this action being ordinarily without the earthquake belt, and no one believing that an earthquake shock was possible here.

Dishes were rattled on the shelves and furniture shake, and doors and walls quivered as they might in a heavy wind.

An earthquake is the result of a fault, or slipping of strata of the earth's backbone, far below the surface, and its vibrations may be felt and reflected for a long distance from the place of the actual fault. 
The vibrations felt here were probably carried for a considerable distance from the point of greatest violence.

Chester, Choteau County, Montana, Thursday May 20, 1909

Local and General News

The earthquake shock that was felt throughout eastern Montana, North Dakota and Alberta, last Saturday night was distinctly felt in Chester.

Northern Montana Experiences Slight Earthquake Shock That Lasted But Few Seconds and Did No Damage

A slight earthquake shock was felt all over Northern Montana at about a quarter past nine Saturday evening. The unusual experiences was rather terrifying to people who had never experienced anything of the kind before. Practically no damage was done however at any point that has so far reported.

The tremor was quite distinct and made practically every building in town quiver, rattling dishes on the shelves and shaking lamps on the tables. Most people rushed out of doors to see what had happened. The shock was a very short one, only lasting about ten seconds. The movement was gradual and light at first, culminating the last few seconds in quite intense tremors. Chickens and animals were badly frightened and ran wildly about.

The quake extended to practically all parts of Northern Montana and was felt over a big stretch of Canada to the north. The shock was felt as far east as Dickinson, N.D.; at Glendive, Great Falls, Helena and Lewistown. In no place was there any damage done except in Helena where a brick wall was shaken down.

\section{The Choteau Acantha, Choteau, Teton County, Montana, May 20, 1909}

A Slight Tremor

Earthquake Shock Saturday Evening.

Some of the people in Choteau Saturday evening felt a slight earthquake tremor at about half past nine. A great many thought that it was a sudden gust of wind; others, however, pronounced it a slight quake, and they were verified by reports that came in from surrounding points. From what residents along the mountains report, the shock was more perceptible there, though not severe, At Great Falls it was stronger still, and at Helena a wall was thrown down, and a number of foundations cracked.

\section{Conrad Observer, Thursday May 20, 1909}

Two slight earthquake shocks were felt in Conrad last Saturday evening about 9:30. They followed each other without any interval. The first shock appeared to carry everything along with it, while the second was of a rattling nature. Both lasted for about 10 seconds. We did not order them.

\section{EARTH TREMBLES}

\section{Culbertson Searchlight; May 21, 1909 page 1.}

The Greater Part of Montana Visited by an Earth Quake Last Saturday Evening.

Citizens of Culbertson were startled Saturday evening. May $15^{\text {th }}$, about 9:10 o'clock by feeling a distinct trembling of the earth which lasted several seconds. Dishes rattled, lamp chimneys fell off, houses creaked and some people were affected with nausea. The following clipped from the Helena Record shows to what extent the quake was felt throughout the northwest:

Distinct earthquake shocks were felt throughout Montana Saturday night about 9:15 o'clock and in some parts of North Dakota and the Canadian northwest. No damage was done by many persons were frightened by the quaking of the earth and rushed from their homes.

At Helena the shock, which seemed to have a north and south motion, was more distinctly felt in the eastern and southern portions of the city and a retaining wall at the residence of Herman Paul at five hundred and ten South Rodney street was hurled down. The wall was ten feet high and two feet thick. All press and telegraph wires entering the city were put out of commission for about twenty minutes as a result of the quake.

At Great Falls, Havre, Wagner, Choteau, Glendive and other cities in the eastern and northern parts of the state the shock was felt and dishes were tumbled from the shelves. At Dickinson, N.D., the shock was 
apparently more severe then [sic] in Montana and the vibration being so forcible that the train dispatchers fled in fear from their quarters.

In the province of Saskatchewan, Canada the shock was also very distinct and at the town of Regina patients in the hospital were hurled from their beds, according to the press accounts.

\section{EARTHQUAKE FELT OVER NORTHWEST}

\section{Culbertson Searchlight; May 21, 1909 page 4.}

Shocks of Alarming Duration Felt in Montana, Saskatchewan and Manitoba.

PEOPLE THROWN INTO PANIC

Reports from Thirty Towns Tell of Violent Tremors, but Contain No Account of Casualties.

Helena, Mont., May 18.- Just recovered from earthquake shocks which occurred here Saturday night and which lasted for several seconds, great alarm has been caused throughout the city by the receipt of advices from many points to the north and south, telling of serious similar shocks which have been taking place throughout this section.

The shocks here lasted several seconds and were distinctly felt throughout the city. The older houses in the town shook violently, people rushed from their homes into the streets in wild bewilderment and for a time it was feared that serious damage had been done.

Tracks Torn Up.

Railroad men reaching here report that the Northern Pacific tracks have suffered to a considerable extent, having been thrown up in several places for considerable distances, and it is feared that unless quick action is taken to advise trains of the conditions grave loss of life may be occasioned.

From Glendive the report comes that very perceptible shocks were felt.

At Dickinson, N.D., it is said the shocks were most severe.

The town of Glasgow, on the Great Northern railroad, was also shaken, and for fully three minutes consternation reigned there.

At Fryburg, N.D., the railway station was badly shaken by shocks which lasted for two minutes.

Felt in Country.

From Great Falls, Mont., it is reported that the earthquake shock was felt there for several seconds. While no serious damage was caused, the shock was of sufficient violence to throw things from the shelves and to cause the people to rush pell mell into the streets.

Choteau, Havre and Wagner, in this state, are also known to have felt the shocks, but the extent to which they have suffered is not known.

From the outlying country districts farmers have brought in news that the shocks were felt everywhere in the locality, and that outhouses and barns have been razed to the ground.

Saskatchewan Badly Shaken.

Winnipeg, May 18.--Reports of Saturday's earthquake in Western Canada continue to come in. The shock was not so severe here as in Saskatchewan province, where goods were shaken from store shelves, and the shock was more abrupt. At Regina patients in the hospital were shaken out of bed, and people rushed in terror from the hotels and big buildings.

Thirty points in telegraphic communication within this city have been heard from, and they all report that the earth tremors were felt and that they last, varying in the different towns, form two to twenty seconds. Instances of slight damage are also reported, but up the present there has been no loss of life.

\section{Culbertson Republican, Culbertson, Valley County, Montana, Friday May 21,} $\underline{1909}$

\section{WE QUAKE}

Last Saturday evening about 9:15 p.m. Culbertson and this vicinity experienced and earthquake shock of some 10 or 15 seconds duration. At first no one seemed to realize what had occurred. Where more than one or two persons were together in a room or building, each blamed the other of moving the furniture, rattling the bric a brac, etc. Soon all realized that a quake had shaken up things and in many instances persons inside the various buildings hurried out into the streets to see what had happened and to inquire of their neighbors if they had noticed anything. The guests in the Evans hotel, a large two-story brick structure, felt the shock very forcibly. Some of them had retired and several screamed and hurried into their 
clothes in order to get out of the building. One gentleman said that he was in a room with another gentleman; that each believed that the other had done something to shake things up; that as soon as they realized what had happened hurriedly went out into the street. The Courchene block, which is also built of brick, was shaken in a like manner. H.G. Walsh and Ralph Bush, who room on the third floor of the Reed Cash Grocery, say that the vibration was so great that a lamp chimney fell off the lamp, and that a small pen knife which was lying near the edge of a table was shaken to the floor.

The family of Prof Dale have rooms in the second story of the Farmers \& Merchants bank, another brick structure. Some young people were there enjoying a social evening. Someone was playing the piano. A vase that was resting on the piano was shaken off and broken. It was thought for a moment that someone had knocked it off.

We were at home and had just gone into one of the bedrooms where the children were sleeping. The whole building seemed to be rocking and the bed was shaking; also the floor seemed to be moving. Our better half accused of shaking the bed in some mysterious manner, and we had the same idea of her.

The same reports come in from the country. The shock was felt all over the country north of here. One neighbor not far from town was visiting another in his neighborhood. They were sitting talking and the table began to move. Each blamed the other of playing some trick until the second shock came and the ceiling of the building began to move. Then they went outside to investigate. This young man who was visiting left his wife at home. She had retired. Soon the bed began to shake. Of course there was a man under the bed. She immediately left the house and took up quarters in the barn until her husband came home. He explained the matter and she was willing to return to the house.

The only damage done here that we have heard of was done in Skelley's barbershop. When asked if he had felt the shock he answered, "Felt it? Will I guess I did. It rang up a 50 cent cash sale on the cash register, and it has been keeping me guessing how I can balance the darned thing. I've got to charge 30 cents for shaves until I get even.”

There appeared to be three distinct quakes here which lasted in all about 15 seconds.

Butte, Mont., May 17.-A score of Montana towns were shaken by an earthquake at 9 o'clock Saturday night.

At Glendive the tremors came with a rush of wind and frightened people rushed into the streets, thinking a tornado was coming. A crowd in the Masonic temple fled precipitately.

A stone well [sic] at Helena was shaken down, dishes rattled and furniture was thrown about

North Glasgow, Havre and Great Falls were severely shaken and the shock was felt as far east as Dickinson and Fryburg, N.D., where telegraphers were frightened from their posts.

The reports indicate that the quake affected a wide territory, extending from southern Canada to the southern limit of Montana.

Winnipeg, May 17.- reports of Saturday's earthquake in western Canada continue to come in. The shock was not so severe here as in Saskatchewan province where goods were shaken from store shelves, and the shock was more abrupt. At Regina, the patients in the hospital were shaken out of bed and the people rushed in terror from the hotels and big buildings.

Glasgow, Mont., May 15, 1909.-Glasgow experienced it's [sic] first earthquake shock at 9:13 tonight. No damage was done here, but it was severe enough to cause people to run from their buildings into the streets. The shock lasted about 10 seconds the wave going from the West to the East.

\section{Daily Pioneer Times; Deadwood, South Dakota; Sundav Mav 16, 1909; page 1}

\section{MONTANA HAS AN EARTHQUAKE}

GREAT FALLS, May 15. - A distinct earthquake shock was felt here this evening at 9:15 and was also felt at Choteau, Havre, Wagner and other point showing that it was prevailing generally throughout the state. While no serious damage was done, the shock was sufficient to throw things from the shelves in stores HELENA, May 15. - Earthquake shocks lasting several minutes were felt here tonight. The only damage reported wan at the residence of Herman Paul, where the front retaining wall was thrown down. GLENDIVE, May 15. - Glendive felt a very perceptible seismic disturbance shortly after 9 tonight. Occupants of the Masonic temple rushed from the building, believing it about to fall. The first shock lasted two or three seconds with unusually rapid vibrations. The shock was felt at Forsythe and Dickinson, N.D. The town of Glasgo [sic] was badly shaken. 


\section{Daily Pioneer Times; Deadwood, South Dakota; Tuesday May 18, 1909; Lead Department}

Did you feel the earthquake shock which visited Lead at 9:30 Saturday evening? Emil Faust and one or two other reliable and trustworthy citizens declare that at that hour two distinct shocks of earthquake took place, sufficient in their intensity to knock down small articles from the shelves and to make things generally move in the rooms in which they were sitting. The shocks were very light and did not anyone much of a scare.

\section{The Dickinson Press, Stark County, North Dakota, Saturday May 22, 1909, page 1}

\section{CITY SHAKEN}

Earthquake Rocks Houses and Rattles Dishes - Many Badly Frightened - Severer In Montana Points - No Damage Done

From western parts of Montana to Dickinson and even points east of here, a very perceptible seismic disturbance was felt shortly after 9 o'clock Saturday evening. It was plainly observed by a large number and the two distinct shocks of several seconds' duration caused a lot of excitement in many homes. Dishes rattled, houses shook and many were frightened. Stories of quite a disturbance are told by many people in the residential section and in some cases the more timid ones rushed from their homes expecting the buildings were about to fall.

People on the second story report the swaying of the walls. It was felt quite plainly in the Elk hall and other parts of the business section. At the telegraph office there was probably the most real trouble and the wires were greatly disturbed for a short time.

Paul Koch tells of quite a little excitement at the German hotel on the South Side. His wife and daughter were alone in the kitchen when the dishes commenced to rattle.

A second shock increased the noise and the dishes on a shelf were nearly knocked to the floor. They were greatly frightened and started to leave the house when the disturbance ended.

The earthquake seemed to be most severe from here west. At Glendive dishes rattled and a number in the Masonic temple rushed out, thinking it was about to fall. In more distant points of Montana the shock was quite severe and at Helena a wall of a residence was thrown down. East of here the shock was little felt. Fargo reports a slight disturbance there.

The Fargo Forum and Daily Republican, Fargo, N.D., Monday Evening, May 17, 1909, page 1

\section{EARTHQUAKE FELT OVER NORTHWEST MONTANA, NORTH DAKOTA AND WEST CANADIAN PROVINCES SHAKEN—SEVERE IN PLACES.}

Glendive, Mont., May 17.- At 9:16 o'clock Saturday evening Glendive felt a very perceptible seismic disturbance. It seemed to be worse in some portions of the city than others. A number of men gathered in the Masonic temple rushed from the building, believing it was about to fall. Dishes rattled in the pantries. The shock lasted probably for two or three seconds with unusually rapid vibrations.

It was first thought a heavy wind was approaching and the volume of a cyclone had struck town. According to telephonic reports received here the disturbance was of wide extent.

It was felt at Forsythe, west of here and at Dickinson, N.D., where it is reported to have been very severe.

Later reports received by train dispatchers here indicate that the strongest disturbance extended from here to Dickinson. East of that point it was very light. The dispatchers in the new Dickinson deport were frightened from their posts. The town of Glasgow on the Great Northern was badly shaken. Later reports from different parts of Glendive also tell of dishes thrown down and broken. The operator at Fryburg N.D. says the building was badly shaken. So far as known Northern Pacific tracks have not suffered.

Prevailed Generally.

Great Falls, Mont., May 17.-An earthquake shock was felt here Saturday night. It was also felt at Choteau, Havre, Wagner and other points, showing that it prevailed generally over northern Montana. While no serious damage was done the shock was sufficient to throw things from shelves.

Wall Thrown Down. 
Helena, Mont., May 17.-At 9:15 o'clock Saturday night an earthquake shock lasting several seconds was felt here. The only damage reported is that of a residence, where the front retaining wall was thrown down. The wall was ten feet high and two feet thick.

The Fargo Forum and Daily Republican, Fargo, N.D., Monday Evening, May 17, 1909, page 2

QUAKE ROCKED N.D. CITIES

TWO DISTINCT SHOCKS FELT AT MEDORA—TELEGRAPH OPERATORS AT DICKINSON FRIGHTENED.

Medora, N.D., May 17. - A slight earthquake shock was felt here Saturday evening about 9 o'clock. Dishes in cupboards rattled and pictures on the walls were disturbed. There were two distinct shocks, at slight intervals and were very noticeable.

Felt at Dickinson.

Glendive, Mont., May 17.--Reports received by train dispatchers indicate that the strongest disturbance extended from here to Dickinson, N.D., east of that point it was very light. The dispatchers in the Dickinson station were frightened from their posts. The town of Glasgow on the Great Northern was shaken badly. Dishes were knocked down and broken here. A report from Fryburg, N.D. says that town was shaken.

The Fargo Forum and Daily Republican, Fargo, N.D., Monday Evening, May 17, 1909, page 8

\section{FARGO FELT THE EARTH TREMOR \\ SLIGHT SEISMIC DISTURBANCE FELT THROUGHOUT THE CITY AT 9 O'CLOCK ON \\ SATURDAY EVENING-MANY PEOPLE FELT THE SHOCK}

That Fargo was slightly shaken by the earthquake which was felt all over the northwest on Saturday evening is now certain. Although the shock was very slight and was probably mistaken for some other cause by a great many people, yet the fact that citizens in all parts of the town are unanimous in stating that they felt a shock or slight trembling of the earth at about 9 o'clock Saturday evening, proves that it was the trembling of the earth.

People on the south side, people in the business district, and people in the residence portion of the north side all have stated that they felt or heard something peculiar at that time.

One woman on the south side was roused by what she thought was some one in the house. She distinctly heard a noise which seemed to come from the next room as of a movement on the floor, but a through search showed that the room was empty. There were many other instances somewhat similar.

\section{The Fargo Forum and Daily Republican, Fargo, N.D., Thursday Evening, May 20, 1909}

MORE REPORTS OF BIG QUAKE

DIRECTOR ROBERTS OF GOVERNMENT WEATHER BUREAU AT BISMARCK GETS REPORTS FROM BOTTINEAU CO.

Bismarck, N.D., May 20.-Director Roberts of the government weather bureau at Bismarck has received official reports from observation stations in the northern part of the state relative to the effects of the quake which was felt through this portion of the state Sunday [should be Saturday] night. The reports received by Mr. Roberts state that effects of the quake were felt very distinctly at different points from Bottineau county across the northern part of the state to Pembina county and in a portion of Canada. A number of citizens of Bismarck living on the high elevation on the north edge of this city claim to have felt it Sunday [should be Saturday] night, especially those who were in the upper story portion of their homes.

Fargo Forum, Fargo, N.D., September 23, 1956

Elk Point 'Crumbling' Recalls Earlier Earth Tremors in Area

By Roy P. Johnson 
Fargo Forum Staff Writer

Contrary to popular belief, earth shocks or tremors such as those reported at Elk Point, S.D., last week are not uncommon although they are not frequent in this section of the country.

Fargo and adjacent territory have experienced several, one of the most recent being that of May 15, 1909.

The tremors came on a Saturday at 9 p.m. and The Fargo Forum reported "there was a slight trembling of the earth, felt or heard in all parts of the city."

One South Side woman, The Forum said, "heard noise and felt the movement of her floor and there were many other similar instances."

Further west in the state the same movement was more severe. "Earthquake rocks Medora, Fryburg and Dickson. [sic]" said The Forum headlines, adding that two shocks were felt in Medora and dishes rattled in cupboards."

"Train dispatchers report the strongest disturbance from Glendive, Mont., to Dickinson." The Forum said. "Glasgow on the Great Northern was shaken badly. Dishes were knocked down and broken."

As late as September, 1933 earth tremors were felt at Rolla, N.D., in the north central area of the state.

"That earth tremors of sufficient intensity to wake him up were felt here in Rolla last Saturday is the sensational statement made by Arthur Dixson, Pasadena, Calif., now here on business." Said the Turtle Mountain Star of Rolla at the time.

"His story was laughed off by everyone until it became known that the seismograph at Montana State College had recorded and earthquake at the exact time Mr. Dixson reported."

Doane Robinson in his "History of South Dakota: quotes Dakota territory newspapers of Oct. 9, 1972, as reporting an earthquake "felt throughout all of the settled portion of Dakota Territory and in northern Nebraska" on that date.

Presumably more severe earth tremors occurred at the Fargo site many thousands of years before the city was settled, as part of the geological phenomena associated with the Ice Age.

Warren Upham and other geologists visiting the Red River Valley to check the shore lines and beaches of glacial Lake Agassiz which 10,000 to 12,000 years ago occupied the valley area were struck by breaks in the levels of the beaches.

In his famed monograph on the ancient lake for the U.S. Geological Survey, Upham noted there had been changes in the slope of the land, with the lake once draining south and later north into Hudson Bay.

"Gravitation of Lake Agassiz toward the ice sheet accounts for a small part of the present inclination of the beaches," Upham said.

"Changes in the temperature of the earth's crust due to the glacial period and its termination produced a still smaller effect, but this tended to give the opposite slope, or a descent to the north.

"Upward epeirogenic [sic] movements rising and falling of land surfaces) resulting from the unburdening of the land by the departure of the ice sheet were the chief element in the causes of the causes of the differential changes in the height of this basin.

"Flow of the plastic inner part of the earth's mass, restoring isostasy (equal pressure from all sides), uplifted first the southern half of the area of Lake Agassiz from Lake Traverse to Gladstone. Next it raised the northern half of the lake area, while the region at the south was almost at rest.

"Finally, during the recent epoch, after the whole basin of Lake Agassiz was passed by this wave-like permanent uplift, it has been elevating the basin of Hudson Bay, where the movement still continues."

Since then, Canadian geologists have continued to record the steady rise of land in the Hudson Bay area and some have forecast an eventual reciprocating earth movement through the central United States area.

Dr. Robert Bell, Canadian scientist, said the uplift of the basin of Hudson Bay is proceeding at the rate of 5 to 10 feet per century.

Daniel Willard, well-known North Dakota geologist, said there is a belief that the uplift of the Hudson Bay basin "is a continuation of the same great movement by which the beaches of Lake Agassiz were lifted out of their level position."

"If the great weight of the vast ice sheet) 1 to 2 miles thick) caused the crust of the earth to bend down or sink," said Willard, "then the melting of the ice wand the flowing away of the water would relieve the pressure and so allow it to rise again. The ice was deeper at the north and the rise of the land, as we have seen, was much greater at the north."

Epeirogenic [sic] movement is going on continuously. Scientists report, for instance, that the coast of Maine is sinking, while the Georgia and Florida coast is rising from the water. 
River coarses [sic] also change. Geologists say the Missouri once flowed north into Canada, at another time south in a channel now followed by the James River.

Elk Point, S.D., founded in the early 1860 's, undoubtedly has experienced more than one earthquake. It lies only 21 miles northwest of Sioux City which has kept a fairly good record of its quakes.

The first on record occurred July 3, 1858, accompanied by a heavy rumbling and an east-west earth movement which shook down pictures and caused crockery to dance on shelves.

Sioux City also noted the 1978 Dakota Territory quake, accompanied by the typical rumbling noise, vibration of buildings. Some residents suffered nervous attacks and dizziness.

The three-story First National Bank building was reported to have "swayed fully two feet."

Sioux City observers said the quake of 1977 was the worst in the city's history.

"The shock was felt throughout Iowa, eastern Nebraska, northwestern Missouri, Kansas, the Dakotas, Wisconsin and Minnesota" they say.

"The area affected was elliptical in form, 600 miles by 300 miles, the vibration being strongest in Missouri valley."

There was a rumble in Sioux City like that of a freight train which gave residents three-quarters of a minute of fright.

Buildings rocked, articles were displaced in homes, clocks stopped, doors opened as if by unseen hands, windows rattled and dishes and tinware tumbled from shelves.

There was a shock, and a "recoil." People poured from buildings into the streets, one court adjourned and in another, the jury agrred on a verdict in less than a minute, said current accounts.

Fortunately no one was hurt but cracks were opened in several buildings.

In explaining earthquakes, seismologists pointed out that although the crust of the earth consists of rock it is not perfectly rigid. Ordinary traffic, the force of waves and other surface activities can cause the surface to vibrate.

A tremor strong enough to be perceptible may be the result of slipping rock strata or the deepening of a fault in bed rock, miles beneath the surface.

Internal concussions cause the earth to quake most violently. Some quakes have been attributed to the collapse of the roofs of subterranean caves.

Conditions favorable to severe shocks are not believed to exist in this part of the country, particularly between the Missouri and Mississippi Rivers.

\section{Forsyth Times, Thursday May 201909}

Local and Otherwise

Montana has known but few earthquake shocks, since its settlement by white men, but a perceptible tremor of the earth was noticed at 9:15 o'clock last Saturday evening. The movement was more distinctly felt in western Montana, although it seemed to be general in this state and the western Dakotas. A few Forsythians, who noted the disturbance, say that it lasted but a few seconds, and had a slight rocking motion, similar to the jar caused by a heavy vehicle in passing.

\section{River Press Weekly, Fort Benton, Wednesday May 19, 1909}

Shaken By Earthquake

The residents of this vicinity and several other parts of northern Montana were more or less disturbed by an earthquake experience Saturday evening. Although it was a gentle jolt, it was the real thing, and the incident suggested that the so-called earthquake belt on the Pacific coast may extend to the Rocky mountain region at some future date.

The phenomenon visited this locality about 9:20 o'clock Saturday night, and lasted but a few seconds. It caused a tremor throughout many business and residence buildings, ad the occupants were at first puzzled to account for the peculiar vibration. Pictures hanging on the wall were swung out of position, and dishes and glassware rang in faint alarm as the quake jingled them together. There was no damage of any kind in this vicinity; it was simply a novel and not altogether a pleasant experience. 
It appears that the quake visited other parts of northern Montana, and was also in evidence at Helena and at various towns in the eastern part of the state. In the capital city a brick wall that was in course of construction was partly wrecked by the disturbance.

The press dispatches state that the earthquake extended north of the international boundary, a report from Winnipeg dated Saturday night being as follows:

A somewhat severe earthquake was felt in Winnipeg tonight at 10:17 o'clock, lasting about 20 seconds. The movement was from north to south. The shock was also felt at Swift Current and at Lanigan, 500 miles west.

Reports from Weyburn and Moose Jaw state that the tremor was sufficient to shake articles off mantels. It seemed to have been felt between Moose Jaw and this city as far north as the Saskatchewan river, ore than 36 points having been reported up to midnight.

\section{Glasgow Democrat, Thursday, 20 May 1909, p. 5}

Wouldn't That Jar You

Glasgow Experiences an Earthquake Shock Saturday Night

No Damage is Done. So All's Well That Ends Well.

Saturday evening last, Glasgow saw visited by an earthquake shock. The experience was so novel, that the average citizen did not at first realize what all the rumbling noises meant, and attributed it to the passing of a heavy freight train through the railroad yards, but when, as one gentleman expressed it, the thing felt as if it were going to kick up behind, then it was the people fully realized that they were up against the real thing, and that old Mother Earth's interior department was pulling off a stunt, by working overtime that was not at all to their liking. It was exactly 9:16 that the first perceptible movement of the earth was felt, and continued for 15 seconds all during the time the earth was swaying and rocking there were continuous rumbling noises that can be best likened to a train passing through a tunnel; it was the grating sound that caused so many people to think it was a cyclone that was upon them, but as the agitation became more severe, and the paper on the walls commenced to crack and pull away then it was that men, women and children fled from the buildings and sought shelter in the open streets, a wise precaution, but fortunately an unnecessary one, so far as Glasgow was concerned. The moment, however, was one of keen apprehension and fear for all; the feeling of not knowing what was to happen, or how soon it would come, was a terrible strain upon both men and women; the sensation caused by the earth trembling and rocking made many sick, and strongly resembled that experienced on board a large steamer in rough weather. There was the rocking and shivering as on a boat in the trough of the sea, an then came that feeling of being lifted up, and momentarially [sic] expecting to be dashed down. It was at best an unpleasant sensation, and while it was to many a decided novelty, it is one no one cares to have repeated.

As soon as the shock was over The Democrat immediately set its force to work throughout the city investigating as to the extent of damage, if any, that had been wrought, fortunately indeed, Glasgow suffered no loss either to persons or property.

The guests of the Coleman house, sitting in the lobby, when they heard the cracking of the paper on the wall, and felt the rocking of the earth rushed out into the street. At the residence of Mr. James Flaherty, living a short distance in the country, the paper was torn from the ceiling; a pile of brick near the Great Northern tracks was thrown to the ground; the clock in the office of attorneys Hurd and Lewis stopped at 16 minutes past nine; in a number of homes dishes were shaken to the floor and pictures on the walls swayed back and forth. The seismic wave, as near as can be ascertained was from the west to the east. Helena, on the other hand, reports it as being from north to south, but one thing that can be put down as a positive fact that from whatever direction it came, it made the people sit up and take notice. The Democrat, learning that no damage had been done in Glasgow immediately sent specials to the near by town in Valley county and neighborhood asking whether any damage had been caused by the shock and to send full reports to The Democrat.

The reports on the streets were to the effect Malta, Chinook and Harlem had suffered great damage. Havre had sustained serious loss, Cut Bank was in very bad shape, while the half of the city of Seattle had been totally destroyed. Reports from these places to The Democrat give the cheerful news that no lives were lost, and little property loss sustained. This is, so The Democrat has been informed, the first time that this section of the state has ever experienced anything of a like nature and it is the universal wish that it may be the last. 
A large section of Montana was visited by an earthquake shock Saturday evening last, and reports at hand, and from special inquires sent out by The Democrat, it is our pleasure to state up to the present writing no lives have been reported lost, and the property damage nominal. While the first reports are liable to be highly colored, yet the indications at hand now are, that the heaviest sufferers will be the Northern Pacific railroad as they had there [sic] track and road-bed thrown up or seriously damaged near Glendive. At Helena great alarm was felt, and people rushed from their homes into the streets in wild bewilderment momentarily expecting to see their dwellings razed to the ground; but the only serious damage done so far reported in the Capital City was the falling down of a retaining wall ten feet height and two feet in thickness, and the shifting of a house to a considerable extent. Some idea of the force of the shock may be imagined when it is stated that the wall that fell was built of brick and heavy masonary [sic] and was intended to with-stand great pressure. The shock was felt at 9:15 and lasted several seconds. At Glendive the shock was very pronounced, it being felt at 9:16 and continued for 18 seconds. The Masons were holding a meeting in Masonic Temple at the time, and when the building commenced to rock the members rushed to the streets fearing the building would collapse.

For seconds the earth shook and consternation reigned supreme throughout the town. No loss of life or property has been reported. At Great Falls the shock was felt for several seconds, no serious damage was done.

The earth's disturbance was violent enough to throw dishes from the shelves and pictures from the walls, and to cause the inhabitants to flee to the open streets. From the outlying districts farmers have brought the news into the different cities and towns in the state that the shocks were felt everywhere, and that outhouses and barns have been razed to the ground.

At Dickinson, N.D., the report comes that the shocks were most severe. The train dispatchers in the new Northern Pacific depot were frightened from their telegraph instruments and ran out of the building. They were prevented from returning to their keys for some time owing to the falling of a wall which succumbed and crashed in like an egg-shell. An Associated Press dispatch from Winnipeg dated Saturday night says:

Earthquake shocks which seem to have followed a general movement from north to south and west were felt here at 10:17 o'clock tonight. They came in quick succession and lasted fully twenty seconds. People rushed from their homes and remained on the streets until all apparent danger had passed.

It is reported from Weyburn and Moosejaw that the shocks were of marked severity there. At Moosejaw walls were shaken to such an extent that there is hardly a house in the city in which the pictures were not thrown to the floor.

Many towns in Saskatchewan are reported to have felt the shocks. Swift Current and Lanigan in that province, about five hundred miles west of Winnipeg, have been [heard?] from and declare that the tremors there lasted for fully ten seconds.

Since midnight thirty points in telegraphic communication with this city have been heard from and they all report that the earth tremors were felt and that they lasted, varying in the different towns, from tow to twenty seconds. Instances of slight damage are also reported but up to the present there has been no loss of life.

Shock Did Good at Havre.

The following specials have been received by The Democrat from points in Valley county and neighborhood.

Havre, Mont., May $16^{\text {th }}$,

Slight seismic disturbance occurred here last evening at about the same time it was felt in Glasgow, but one hundred miles west was not preceptable [sic] and I am inclined to the opinion that it did considerable good as church services were more generally attended here today than for some time past, despite inclement weather. -Havre Plaindealer.

Not Very Severe.

We experienced the same shock, at the same time, you did and for the same time. It was not very severe, about the same at [sic] it was down there I think. -Harlem News.

Scare for Everyone.

Chinook, May 16.-We experienced the same earthquake shock about nine o'clock, the first ever felt in this vicinity. No serious damage was done here. The breaking of a few dishes and a good scare for everyone was the extent of the damage.-Chinook Opinion.

Thought Millenium [sic] had Come. 
Malta, May 18.- Malta and vicinity experienced a slight earthquake shock at 9:20. Saturday evening, the seismic disturbance was from north to south. Some buildings were shaken, causing dishes to fall from shelves, but no damage is so far reported. Many people were badly frightened, imagining the millenium had come. - Malta Enterprise Pub. Co.

Not Felt at Cut Bank.

Cut Bank, May 17.-We did not feel anything here at cut Bank, and now west of here to my knowledge. R.C. Rasmussen.

Last Saturday evening at 9:15 the citizens of Culbertson experienced something that was entirely new to them - an earthquake shock. So far as we can learn, the shock was felt by everyone who was inside a building. Those who were on the street did not feel it. The Evans hotel and Courchene building both of which are brick structures were shaken. Vases and other fragile things were shaken off shelves and other resting places and broken. No one was particularly frightened, and in fact is was some little time before it was really known what had taken place. Three seemed to be three distinct shocks which lasted in all about 15 seconds. - Culbertson Republican.

NASHUA NEWS.

A sensation like an earthquake was felt among the citizens of Nashua last Saturday night about 9:15 o'clock. Some of the boys laid it to the Nashua booze, but next day reports proved it to be real.

\section{Valley County News; Glasgow, Montana, Friday May 21, 1909}

\section{A SEISMIC DISTURBANCE}

This County Visited By a Very Distinct Earthquake

Last Saturday night about 9:20 o'clock, the whole town was thrown into excitement by two earthquake shocks. The first was quite light and many did not notice it, but the second was very pronounced and lasted about 10 or 12 seconds. In a few moments the streets were full of people and everybody was telling everybody else what had happened. No damage was done here, but lamps, dishes and furniture showed by their antics that we were having a genuine earthquake.

During the night, about eleven o'clock and fine the next morning, two other light trembles were felt, and by the middle of the forenoon reports were in from both east and west, and showed that the earthquake reached as far west as Helena and east to Williston, the wave seeming to move from west to east, and was heaviest in the vicinity of Harlem and Chinook.

No theory or special cause for the earthquake has been figured out by our local geologists so we will have to attribute it to our being close to the geyser district of the Yellowstone park.

Nashua, May 18.-Quite an earthquake shock was felt here a few minutes after nine o'clock Saturday evening, and another slight quake about five o'clock Sunday morning.

Malta, May 18.- Saturday night at 9:15 this vicinity was visited by an earthquake shock. Houses shook and windows and dishes rattled but no serious damage was done.

Culbertson, May 18. - The citizens of Culbertson were treated to an earthquake Saturday night; last night they had a dance.

\section{Yellowstone Monitor, Glendive, MT, Thursday May 20, 1909, page 1.}

\section{CITY HAS A GENUINE QUAKE}

Effects of the Earth Tremors Seem To Have Covered a Very Wide Area.

Glendive experienced a rather severe earthquake shock about 9:15 o'clock Saturday evening. The tremor lasted for several seconds, with very rapid vibrations, and was felt in all parts of the city. While no damage of any consequence has been reported, several of the residents were given good scares. The shock was noted by a large audience gathered in the Opera House, and several other smaller meetings in the city. But at the worst, dancing furniture has been about all that has been reported.

The shock seems to have been general throughout this section of the country. It extended east of Dickinson, and at the latter city gave several railroad employes [sic] and others a server frightening. It was also plainly felt at the other points west.

At Helena houses were badly shaken, and at the residence of Herman Paul on Rodney street, the front retaining wall was thrown down. This wall was 10 feet high and 2 feet thick. 
From Great Falls came a report that three distinct shocks were felt. Also at Havre, Glasgow, Saco, Choteau, Malta and Zortman, besides smaller places, the shock was quite severe. At Wagner, Choteau county, the disturbance is reported to have lasted 30 seconds, and appeared to run from north to south.

Messages from Winnipeg said that a severe shock was felt shortly after 10 o'clock. At Weyburn and Moose Jaw, the tremor was sufficient to shake articles off mantles. About 40 Canadian points were reported later on, so it can be judged that the tremors covered a very wide area.

In spite of the apprehension caused here at the time, there is not one chance in a thousand of the occurrence of a tremor of sufficient power to cause heavy damage and loss of life, in this section of the country. As this paper stated some time ago, for the very nature of this district, slight shocks were not an improbability, but heavy seismic disturbances are usually met with on the sea coast or in the near vicinity of volcanoes. This country, throughout the Bad Lands region, shows evidences of great volcanic activity in the remote past, but the time was no doubt several million years ago, so there is no immediate danger of the earth opening and swallowing the populace. Buildings containing large quantities of masonry are the one always first thrown down.

People coming in from various sections of the country report disturbances approximately similar to those which occurred here.

No section is entirely free from these earth tremors. Even in the prairie states have occurred light disturbances similar to those which visited Glendive and vicinity last Saturday evening. Seismologists, or those who probe into the causes of earthquakes, have as yet advanced no theory that seems applicable to all the cases heretofore reported. Nevertheless, local people have had a unique experience.

\title{
Yellowstone Monitor, Glendive, MT, Thursday May 20, 1909, page 8.
}

\section{Enid Enumerations}

Saturday night between 9 and 10 o'clock we felt a very distinct earthquake shock lasting about two minutes, the vibrations being from north to south. The shock was felt three miles east of us and one mile south, being as far as we have hear from the people at present.

Newsy Newlon Nubbins

An earthquake shock was felt at Newlon on May 15, at about 10 p.m., and lasting about two minutes.

\section{Dawson County Review, Glendive, MT, Friday, May 21, 1909, page 6.}

\section{THE EARTH TREMBLED AND GLENDIVE KNEW IT \\ GLENDIVE EXPERIENCES THE UNUSUAL NOVELTY OF A GENUINE EARTHQUAKE.}

Glendive experienced a decided novelty last Saturday evening at 9:16, when people of the city felt the very perceptible tremors of an earthquake lasting for several seconds. It seemed stronger in some places than others. People on the streets felt it little, if at all. In some homes, dishes rattled on the pantry shelves.

A number of men who were gathered in Masonic temple were startled by the vibrations of the building, and thought it best to decamp at once. Some who were in the opera house were also frightened. Groups soon gathered on the streets to discuss an experience never before chronicled in the city's history, as far as The Review can learn.

The visitation was of wide extent, and Glendive as apparently about in the middle of it. At Helena a two-foot retaining wall was thrown down. Along the Great Northern railway some places reported a double shock, accompanied by a low, rumbling sound.

At Dickinson, it is said, the disturbance was quite severe causing dispatchers to leave the new depot building. Winnipeg is the point farthest east reporting the "quake".

\section{Great Falls Daily Tribune, Great Falls, Montana, Sunday Morning May 16, 1909}

\author{
A SHOCK \\ Earthquake Felt All Over This Part of the State.
}


Northern and Central Montana last evening experienced slight earthquake shocks, which had the effect of frightening many people, but which did no damage of any appreciable extent. According to the reports received by The Tribune, the shocks occurred at various localities at different times between 9:10 and 9:20 o'clock.

Residents of Great Falls in all parts of the city felt the shock at about 9:15 o'clock. The earthquake was more violent, according to the statements of most people, in the vicinity of Eighth avenue south and on the North side, east of Ninth street, than in the business district. Many people in the residence districts were so frightened that they ran out of their houses. In one or two instances pictures were thrown from the wall, and bottles were jarred from their shelves in a few of the business houses of the city.

The earthquake caused considerable excitement in all parts of the city.

FELT AT GLENDIVE.

Glendive, May 15,-At 9:15 o'clock this evening Glendive felt a very perceptive [sic] seismic disturbance. It seemed to be worse in some portions of the city than in others. A number of men gathered in the Masonic temple rushed from the building believing it was about to fall. In many houses dishes rattled in the pantries. The first shock lasted probably tow or three seconds with unusually rapid vibrations. At first it was thought a heavy wind was approaching. According to telephone reports received here the disturbance was of wide extent.

Reports received by train dispatchers here indicate that the strongest disturbance extended from here to Dickinson N.D., east of that point being very light. The dispatchers in the new Dickinson depot were frightened from their posts.

GLASGOW SHAKEN. Special to The Daily Tribune.

Glasgow, May 15,--Earthquake shock was felt here at 9:16 tonight. Buildings shook, windows rattled and a few dishes were broken. There was on serious damage.

AT MALTA AND ZORTMAN.

Special to The Daily Tribune.

Malta, May 15,--This city was thrown into considerable excitement this evening about 9:20 p.m., when an earthquake shock passed through. It lasted about thirty seconds. However, no damage was caused by the shock, although windows rattled as thought a strong wind was blowing. Dishes in some of the lighter homes were rattled from their accustomed places. It is the consensus of opinion that the quake passed through the entire valley. The shock was also felt at Zortman; 50 miles south, according to telephone messages.

FROM NORTH TO SOUTH. Special to The Daily Tribune.

Wagner, Montana., May 15,--A distinct earthquake shock occurred here at 9:16 this evening, buildings rocked; and the low, rumbling sound suggested the passing of a train. The disturbance seemed to run from north to south, and was of about 30 seconds' duration.

LIKE A HEAVY WIND.

Special to The Daily Tribune.

Saco, May 15,--An earthquake struck here at 9:15 p.m., shaking all buildings quite badly but no damage was done. There were two waves, the first one light, followed closely by a second one which was heavier, lasting eight or nine seconds. The first shock shook buildings like a heavy wind.

SHORT AT HAVRE.

Special to The Daily Tribune.

Havre, May 15,--A distinct shock of earthquake was felt here at 10 minutes after 9 o'clock tonight. Frame buildings and even brick buildings shook so that people were frightened. At first the inmates of buildings supposed a heavy wind had struck, but a continuance of the shaking dispelled the idea. The shocked lasted probably three seconds.

AT LEWISTOWN.

Special to The Daily Tribune.

Lewistown, May 15,--An earthquake shock that lasted for several seconds was felt here slightly this evening at 9:12 o'clock. Reports of the shock were received from a number of points in Fergus county, but no damage was reported.

AT CHOTEAU.

Special to The Daily Tribune. 
Choteau, May 15,--A slight earthquake shock was felt by the residents of this town at 9:10 o'clock this evening. The shock appeared to last about five seconds and it caused considerable excitement, although no damage was done. Reports of the earthquake were received by telephone form a number of points surrounding here.

THREW DOWN A WALL.

Special to The Daily Tribune.

Helena, May 15.-At 9:15 o'clock tonight an earthquake shock, lasting several seconds, was felt here. A number of people have reported that their houses were distinctly shaken and that dishes rattled. The only damage reported is that at the residence of Herman Paul, 510 Rodney street, the front retaining wall of the house was thrown down by the shock. The wall was 10 feet high and 2 feet thick. Shocks have also been reported from Glendive and other towns in the eastern part of the state.

ACROSS THE BORDER

[Article cut off at this point]

\section{Great Falls Daily Tribune, Tuesday May 18, 1909}

\section{EARTHQUAKE IS RECORDED}

Instruments at Cheltenham, Md., Instantly Recorded Shock of Saturday Night.

Washington, May 18,-An earthquake estimated at 3,000 miles distant was recorded at the Cheltenham, Md., Magnetic observatory of the United States coast and Geodetic survey today. The report showed tremors of more than average amplitude. They began at 3:12 o'clock this morning, seventy fifth meridian time. The maximum waves occurred at 3:22 and the tremors ended at 4:18.

A moderate earthquake was also recorded at Cheltenham last Saturday night, beginning at 11:16. Its indicated origin was about 1,750 miles distant and probably is the one reported in Montana.

\section{Great Falls Daily Leader - May 17, 1909}

Great Falls and all of northern and central Montana experienced a slight earthquake Saturday evening. The quake was extremely perceptible in the city for a period of 10 seconds about 9:15 during which buildings trembled, windows rattled, dishes and bottles jingled in cupboards, and in several places pictures were shaken from walls. In many of the downtown's larger office blocks the shock was little if at all noticed, but in the residence districts it was very noticeable. Many persons were frightened and ran out of houses.

\section{The Harlem News, Harlem, Montana, Thursday, May 20, 1909}

\section{HARLEM IS SHAKEN}

By Earthquake-Shock Felt Over This Part of State.

Northern and central Montana Saturday evening experienced slight earthquake shocks, which had the effect of frightening many people, but which did no damage of any appreciable extent. According to the reports received by the News, the shocks occurred at various localities at different times between 9:10 and 9:20 o'clock.

Residents of Harlem felt the shock at about 9:15 and lasted but a few seconds. In some homes dishes were rattled and windows shaked [sic] but nowhere in this vicinity was any damage done. Those who were outside felt no shock.

From points as far east as Dickinson, N.D., west at Havre and south as far as Glendive and Great Falls comes reports of the shock. It was also felt in Canadian points north and east of here. The disturbance seemed to run from north to south and was from 10 to 30 seconds duration.

Unconfirmed reports state that a brick house was destroyed at Williston. At Helena a stone wall two feet thick and ten feet height was thrown down. The Harlowton News, Harlowton, Meagher County, Montana, Friday May 21, 1909

The Harlowton News, Harlowton, Meagher County, Montana, Fridav Mav 21, 1909 


\section{EARTHQUAKE}

Shock Felt by the People of Harlowton

Also by Those of Other Towns

Harlowton was visited with a slight earthquake last Saturday night. The shock was quite perceptible in many of the larger buildings. It came about 9:15 and the tremor was sufficient to attract general attention, although few understand the cause. Those who were indoors could notice the vibrations distinctly. Water in glasses could be seen to tremble, and electric light globes were set swinging. Many attributed the disturbance to the wind.

Those who were in the new Graves hotel say that the shock was perceptible for several seconds, and later the belief was confirmed that a small earthquake had visited the town. The next day brought reports from Great Falls and Lewistown that buildings there had been shaken. The following statement from Great Falls shows that the shock was general in this section of the state;

Great Falls, May 15,--An earthquake shock of several seconds' duration, which was quite severe occurred here this evening at 9:15 o'clock.

Building in all parts of the city were shaken and many residents were so frightened that they ran out of their houses onto the streets. Bottles were jarred from shelves in a number of buildings, but no damage of any extent has been reported.

There were apparently three shocks, which came in such quick succession that the time elapsing between them was hardly noticeable. A dispatch to the Tribune from Havre stated that a distinct shock was felt there at 9:10. Buildings shook so that people were frightened, and many ran out of them. The shock lasted only a few seconds.

A shock was reported to have occurred at Wagner, Choteau County, at 9:16 p.m. Buildings rocked, and the low rumbling sound suggested the passing of a heavy train. The disturbance there appeared to run from north to south, and was of about 30 seconds' duration.

Saco, Valley County, reported a shock at 9:15. Buildings were badly shaken, but no damage was done. There were two waves, a light one being followed closely by a second, which was heavier, lasting eight or nine seconds.

Choteau, Teton County, reported a heavy shock at 9:12, which lasted several seconds, and was felt by practically the entire population of the town.

Vaughn, Cascade County, reported a rather violent shock at 9:15, but no damage was done.

A dispatch from Malta, Valley County, states that the people of that town were startled by a shock about 9:20 p.m. which lasted about 20 seconds. Windows rattled, and dishes in some of the houses were shaken from shelves.

A message from Zortman, in the Little Rockies states that the shock was felt strongly there but no damage reported.

SHARP AT GLENDIVE

Glendive, May 15,--At 9:16 o'clock this evening Glendive felt a very perceptible seismic disturbance. It seemed to be worse in some portions of the city than in others. A number of men gathered in the Masonic Temple rushed from the building believing it was about to fall. In many homes dishes were thrown down and broken. The shock lasted probably for two or three seconds with unusual rapid vibrations. It was at firs thought a heavy wind approaching the volume of a cyclone had struck the town. According to telephone reports received here the disturbance was of wide extent. It was felt at Forsyth west of here.

Reports received by train dispatchers indicate that the strongest disturbance extended from here to Dickinson, N.D., east of that point it was very light. The dispatchers in the new Dickinson depot were frightened from their posts. The town of Glasgow, on the Great Northern, was badly shaken.

HELENA HOUSE DAMAGED

Helena, May 15,--At 9:15 o'clock tonight an earthquake shock lasting several seconds was felt here. A number of people have reported that their houses were distinctly shaken and that dishes and furniture rattled. The only damage reported is that at the residence of Herman Paul, 510 Rodney street, the front retaining wall of the house having been thrown down by the shock. The wall was ten feet high and two feet thick.

Havre Plaindealer, Havre, Montana, Saturdav, Mav 22, 1909 
Earthquake Felt in Havre on Saturday Night Last Was General Throughout the Northwest

Havre, in common with all northern and eastern Montana, experienced a slight earthquake shock last Saturday evening a few minutes past nine o'clock. The quake was sufficient to rattle dishes upon the table and make the incandescent bulbs dance weirdly. Buildings all over the city quaked and in the Hotel Havre a number of people sought the street and they stood not upon the order of their going. A few of the early to bed patrons hustled out in their pajamas and nighties, [sic] and the exodus at the hotel was not unlike that in other building blocks in the city.

It was more plainly felt probably in the residence portion of town than in the business district, and felt not unlike a bridge vibrating with a heavy load passing over it, the team on a trot. Many people ran from their homes to ascertain the cause, and it was the following day before most of them learned that a seismic disturbance was what they experienced.

The shock extended from Dakota on the east to this side of Chester on the west, and from Winnipeg, Canada, on the north, to the southern part of the state. From the reports the shocks occurred at about the same time all over the country, between 9:10 and 9:20 o'clock. The shock in Havre lasted probably five seconds, and did absolutely no damage.

At Glendive the earthquake was very apparent and a large number of people assembled in the Masonic temple rushed from the building, believing it was about to fall.

The shock was felt at Glasgow but no damage was done. It is reported that the earth tremble was noticed there for a period of about 30 seconds. At Saco there were two distinct shocks but no damage was done.

Lewistown and other points in Fergus County experienced slight shocks.

From Choteau come reports of a quake in that place and surrounding points of about five seconds' duration.

At Helena the retaining wall of a residence, about five feet high and two feet thick, was thrown down, but no other damage was reported.

From Winnipeg, Man., come reports of a similar disturbance which was felt in that place, and that it extended to Lanigan, Sask., and as far north as the Saskatchewan river.

\section{The Helena Independent}

\section{EARTHQUAKE HITS HELENA \\ DISTINCT SHOCK FELT THROUGHOUT THE NORTHERN PART OF MONTANA RESIDENCE IS DAMAGED}

Ten-foot Wall is Shaken Down on Rodney Street-Furniture and Dishes Are Rattled in Various Parts of the City-Swaying Motion From North to South Is Distinctly Perceptible.

Montana was visited by an earthquake last evening. In Helena furniture and dishes were rattled and walls were shaken down. The shock was felt throughout the northern section of the state and in places was severe. From Glendive, Malta and Great Falls special dispatches reached The Independent telling of the quake, and in Helena the shock was distinctly felt.

At 9:15 o'clock last evening a shock lasting several seconds was felt by various residents. It had a swaying motion from north to south. A.W. Ide felt the quiver of the earth at his residence. At the Walker store, on the corner of Davis street and Broadway, it was felt so strongly that the people on the second floor rushed down stairs in fear, and a sleeping baby was awakened. Mr. Walker was seated in his store and the tremor rocked the chair as though it rested on rockers.

Wall Crumbles.

The only damage reported as a result of the shock was that at the residence of Paul, 510 Rodney street, where the front retaining wall of the house was thrown down by the shock. The wall was ten feet high and two feet thick and crumbled before the quake like a stack of cards.

The quake was felt in The Independent office, and for 20 minutes the wires connecting this office with the outside world were put out of commission. The quake seemed to have been more apparent in the southern and eastern portions of the city than elsewhere.

It was reported last night that the earth had cracked open in Helena and that a fissure two feet wide had opened on Rodney street. This rumor was investigated and was found to be untrue. From all the towns in the northern part of the state reports of seismic disturbances arrived last night.

SEVERE AT GLENDIVE.

Butte, May 15.-A Miner special from Glendive says: 
At 9:15 o'clock this evening Glendive felt a very perceptive [sic] seismic disturbance. It seemed to be worse in some portions of the city than in others. A number of men gathered in the Masonic temple rushed from the building, believing it was about to fall. In many houses dishes rattled in the pantries. The first shock last [sic] probably two or three seconds with unusually rapid vibrations. At first it was thought a heavy wind was approaching. According to telephone reports received here the disturbance was of wide extent. It was felt at Forsyth, west of here, and at Dickinson, N.D., where it is reported to have been very severe.

Frightened From Posts.

Later reports received by train dispatchers here indicate that the strongest disturbance extended from here to Dickinson, N.D., east of that point being very light. The dispatchers in the new Dickinson depot were frightened from their posts.

The town of Glasgow, on the Great Northern, was badly shaken.

Reports from different parts of Glendive also tell of dishes thrown and broken. So far, the Northern Pacific tracks have not suffered.

The operator at Fryburg, N.D., says his quarters felt the shock.

WINDOWS RATTLED.

Malta, Mont., May 15,--This city was thrown into considerable excitement this evening about 9:30 o'clock, when an earthquake shock passed through. It lasted about 30 seconds. However, no damage was caused by the shock., although windows rattled as though a strong wind was blowing. Dishes in some of the lighter homes were rattled from their accustomed places. No one has been able to account for the shock and it is the consensus of opinion that the quake passed through the entire valley. The shock was also felt at Zortman, 50 miles south, according to telephone message.

SHOCK WAS GENERAL.

Great Falls, May 15,--A distinct earthquake shock was felt here this evening at 9:14 and it also was felt at Choteau, Havre, Wagner and other points at the same time, showing that it prevailed generally over northern Montana. While no serious damage was done the shock was sufficient to throw thing from shelves in stores and there was some breakage of glassware.

TREMOR FELT IN WINNIPEG.

Winnipeg, Man., Man 15-A somewhat severe tremor was felt in Winnipeg tonight at 10:18 o'clock lasting about 20 seconds. The movement was from north to south. The shock was also felt at Swift Current and at Lanigan, 500 miles west.

Reports from Weyburn and Moose Jaw that the tremor was sufficient to shake articles off mantels. It seemed to have been felt between Moose Jaw and this city as far north as the Saskatchewan river, more than 36 points having been reported up to midnight.

\section{Montana Homestead, Hinsdale, Valley County, Montana, Friday May 21, 1909}

\section{LOCAL NEWS NOTES.}

All northern Montana experienced an earthquake shock last Saturday evening at about 9:15 o'clock. While little damage is reported a good shaking up was experienced. At Hinsdale the quake lasted about 3 seconds and was severe enough to cause most all the people to leave their buildings, and those who had retired for the night were shaken so that they got out of bed. In the business portion of the town people ran into the street expecting other shakes to follow. This was the first earthquake many of our people had experienced, and having read of so much disaster from the effect of e quakes in others parts of the world, some of them were quite badly frightened.

\section{Livingston Enterprise, Livingston, Montana May22, 1909}

\section{MONTANA EARTHQUAKE.}

Distinct Shocks Felt at Different Places in State.

Great Falls, May 15.-An earthquake shock of several seconds' duration, which was quite severe, occurred here this evening at 9:15 o'clock. Buildings in all parts of the city were shaken and many residents were so frightened that they ran out of their houses onto the streets. Bottles were jarred from shelves in a 
number of buildings, but no damage of any extent has been reported. There were apparently three shocks, which came in such quick succession that the time elapsing between them was hardly noticeable.

A dispatch to the Tribune from Havre stated that a distinct shock was felt there at 9:10. Buildings shook so that people were frightened, and many ran out of them. The shock lasted only a few seconds.

A shock was reported to have occurred at Wagner, Choteau county, at 9:16 p.m. Buildings rocked, and the low rumbling sound suggested the passing of a heavy train. The disturbance there appeared to run from north to south, and was of about 30 seconds duration.

Saco, Valley county, reported a shock at 9:15. Buildings were badly shaken, but no damage was done. There were two waves, a light one being followed closely by a second, which was heaver, lasting eight or nine seconds.

Choteau, Teton county, reported a heavy shock at 9:12, which lasted several seconds, and was felt by practically the entire population of the town.

Vaughn, Cascade county, reported a rather violent shock at 9:15, but no damage was done.

A dispatch fro Malta, Valley county, states that the people of that town were startled by a shock about 9:20 p.m., which lasted about 20 seconds. Windows rattled, and dishes in some of the houses were shaken from shelves. A message from Zortman, in the Little Rockies, states that the shock was felt strongly there, but no damage was reported.

[Editorial Comment] MONTANA'S EARTHQUAKE.

Not to be outdone by any other state or county in anything, Montana experienced a slight upheaval, of the seismic order Saturday evening of last week. It is true that it was not felt in all parts of the state, but wherever it appeared and made its presence know the shock was so distinct and clear as to leave no doubt of the genuineness of the article.

According to all reports the quake started in or near the vicinity of Helena and extended easterly as far as Malta, Valley county. From there north there were slight quakes at different places, and as far south as Glendive and as far west again as Billings, the vibrations were apparent.

Livingston, of course, did not feel the shock. This city is yet in its infancy, from the booster's standpoint, and it is not to be expected that any of the sensation would permeate this part of the state.

Helena, true to its natural inclination, and enjoying the inalienable right to hog everything in sight, experienced by far the severest shock of any other part of the state. The ground actually rose and fell in the Main street of that city, returning again to its natural condition without a break in its surface. Walls also crumbled and fell, and wherever it was felt in the capital city it was by far more severe than in any other part of the state, all of which was meet an proper.

Then again, Billings felt the sensation in a manner truly in keeping with the rapid progress being made by that place along the boosting line. It is true the disturbances around that part of the geographical makeup of Montana were not so great as in Helena, but then Billings is not the capital, neither is it as old in the commercial, industrial, social or political world as the city in Last Chance gulch.

But, as a whole, the quake was a success. It seems to have visited the places most entitled to it, and fortunately, it did no other damage than to shake up the residents and bring them again to a sense of their responsibility as the chief center of the great and growing state of Montana.

\section{MILES CITY: STOCKGROWERS JOURNAL - Monday May 17, 1909 MILES CITY: DAILY YELLOWSTONE JOURNAL - Monday May 17, 1909}

[both papers have identical story]

- not a full grown earthquake to be sure, just a gentle tremor

- $\quad$ not felt in street, scarcely perceptible on the first floor dwellings, and had to be supported by collaborators evidence by person on second floors before they were sure it was not their imagination.

- $\quad$ Between 9:15 and 9:16

- $\quad$ Dishes rattled and in some houses furniture moved around like in a spiritual scene.

- Complained of bed moving.

Dispatches from other towns:

Glendive:

- dishes rattled, some broken 
- $\quad$ unusually rapid vibrations for 2 or 3 seconds

Dickinson

- greatest disturbance seems to be between Glendive and Dickinson

- $\quad$ ran out of buildings frightened

Fryburg

- buildings badly shaken

Mondak Montana, Saturday, May 22, 1909

A Slight Shock Felt.

Saturday evening at 9:15 there was a good deal of excitement in our little city when people discovered that dishes were rattling and tables moving without any apparent cause. The earthquake shock lasted for about 30 seconds and was quite severe in places but not damage was done in the city. The shock was general over the state of Montana, and the western parts of North Dakota and parts of Alberta and Sask., Canada, but from all reports the strongest at Helena and Butte.

NORTHWEST HAS EARTHQUAKE.

Tremor Believed to be an "Echo" from South America.

Winnipeg, Man., May, 17.-When the earthquake shocks were felt here Saturday evening efforts were immediately put forth to ascertain the extent of the territory covered by the tremors and the amount of the damage inflected.

Telegrams were sent out from Winnipeg to various places, and in some instances emissaries were dispatched from certain centers to inaccessible points.

Compilation of the reports received here Sunday reveal the fact that shocks varying in intensity were felt all through Canadian prairies west at about 10:20 o'clock central time Saturday evening, in most places rattling dishes, banging doors and shaking windows, while at several points people were driven in alarm out of doors.

At Wolseley the well of the electric light plant caved in just before the shock was felt and the town was plunged in darkness.

At Regina patients in the hospital were shaken out of bed and people rushed in terror from hotels and big buildings.

Other places reported cracked plaster, but that appears to be the sum of the damage done.

The shock was very light in this city, but was distinctly felt at Selkirk on Lake Winnipeg and from there the disturbance was noted at scattered points for 1,000 miles west across the prairie.

Shocks appear to have been most severe in the heavy "Gumbo" country of Saskatchewan along the main line of the Canadian Pacific, but were felt as far north as Prince Albert.

It is the first time in known history that earthquake shocks have visited the Red river or Saskatchewan valleys and Professor Frank Allen, Ph. D. of Manitoba university, said last night that they might never recur.

Rapid City Daily Journal; Rapid City, South Dakota, Sunday morning, May 16, 1909

\author{
SHOCKED RAPID CITY \\ SEISMIC DISTURBANCE PERCEPTIBLE HERE SATURDAY EVENING \\ OCCUPANTS OF BUSINESS BLOCKS WERE GIVEN SCARE-OTHER CITIES SHAKEN \\ Rapid City and vicinity felt a perceptible seismic disturbance Saturday evening at 9 o'clock and \\ there were many persons who believed that the city was about to experience an earthquake. In several \\ instances brick buildings standing alone trembled and frightened the occupants to such an extent that they \\ fled in fear that the structures would fall. The shock here, however, was slight as compared to that felt at \\ other points within a few hundred miles, according to Associated Press dispatches received at an early hour \\ Sunday morning. \\ Glendive, May 15. - Glendive felt an earthquake shock between 9 and 10 o'clock Saturday night. \\ Occupants of the Masonic temple rushed from the building, believing that it was about to fall. The first \\ shock lasted two or three seconds, with an unusually rapid vibration. The shock was also felt at Forsythe \\ and at Dickinson, N.D. The town of Glasgow was also badly shaken.
}


Great Falls, Mont. May 15. - A distinct earthquake shock was felt here tonight at 9:15 o'clock. It was also felt at Chotau [sic], Harve [sic], Wagner and other points, showing that it was general throughout the state. While no serious damage was done, the shock was sufficient to throw things from shelves in stores.

Helena, Mont., May 15. - An earthquake shock lasting several minutes was felt here tonight. The only damage reported was to the residence of Herman Paul, where the front retaining wall was thrown down.

\section{SIDNEY HERALD - Friday May 21, 1909}

EASTERN MONTANA GETS A GENTLE SHAKING FROM EARTH'S BOWELS

Saturday evening at about nine o'clock the eastern part of Montana experienced a slight earthquake. Reports from Mondak, Fairview, Culbertson and Girard all tell of a slight rumbling of the earth, and in some instances buildings were shaken and dishes rattled. However we are glad to report, "all safe on the Yellowstone."

\section{TERRY TRIBUNE - Friday May 21, 1909}

"It came along gently about 9:30 and made those who retired feel like the timid woman who always had to look for a man under the bed. The sensation was as if someone was under the bed trying to lift it." Peculiar feeling, experienced by more than on Terryite.

\section{WIBAUX PIONEER - Thursday May 20}

Quite a distinct earthquake shock was felt in Wibaux last Saturday evening at 9:10 o'clock and according to reports from up and down the line, it was much more severe at other towns.

\section{The Williston Daily Herald, Williston North Dakota, May 19, 1909}

\section{EARTHQUAKE SHAKES MONTANA}

Shock Also Felt at Dickinson and Other Points in North Dakota

Butte, Mont.,--A score of Montana towns were shaken by an earthquake at 9 o'clock Saturday night At glendive the tremors came with a rush of wind and frightened people rushed into the streets, thinking a tornado was coming. A crowd in the Masonic temple fled precipitately [sic].

A stone wall at Helena was shaken down, dishes rattled and furniture was thrown about.

North Glasgow, Havre and Great Falls were severely shaken, and the shock was felt as far east as Dickinson and Fryburg, N.D., where telegraphers were frightened from their posts.

Shaken Out of Bed

Winnipeg, May 17.--Reports of Saturday's earthquake in western Canada continue to come in. The shock was not so severe here as in Saskatchewan province, where goods were shaken from store shelves, and the shock was more abrupt. At Regina, the patients in the hospital were shaken out of bed, and the people rushed in terror from the hotels and big buildings.

\section{The Williston Daily Herald, Williston North Dakota, May 19, 1909}

Brief Local News

On Saturday night the earthquake shock which was felt here was reported from many points over the middle West. We note that about the strongest effect was felt at Butte, where the glass in the windows of many homes was broken. In Havre some slight damage was done but, nothing to speak of. We have not noted any other damage from other points. 
Williston Graphic, Williston, Williams County, N.D., Thursday, May 20, 1909

AN EARTHQUAKE SATURDAY NIGHT

Slight Shock Felt Saturday Night About Ten-Thirty—Shock Felt Throughout Northwest

A great many of our citizens were alarmed Saturday night when a slight earthquake shock was felt. Parties in dwelling houses and those living upstairs in the flats in the business portion of the city noticed more of a shock than others. The quake was felt throughout the western part of the state, through Montana and in portions of Manitoba. In Glasgow and Havre the shock knocked glasses from tables and shook down chimneys.

\section{ZORTMAN - Little Rockies Miner}

"which we all felt plainly"

"building were considerably rocked by waves extending over a period of one minute" 


\title{
Appendix B. Newspaper accounts from Saskatchewan archives (Key phrases for Modified Mercalli Intensity assignments are underlined)
}

\author{
Alameda Dispatch May 211909
}

\section{EARTHQUAKE SHOCK}

A distinct earthquake shock occurred on Saturday night and was perceptible all over the three prairie provinces. No damage was done but much interest was aroused by the experience of a phenomenon from which the northern part of the North American continent was supposed to be immune. Comparatively few people were aware that a seismic disturbance had taken place till the following morning and many did not know till the reports appeared in the daily papers.

The severity of the shock varied considerably at different places. Some towns have nothing worse to complain of but a slight rumbling, while elsewhere articles were shaken from store shelves. In districts where two shocks were reported the second was invariably the stronger. The duration of quake varied from 10 to 35 seconds.

A number of local people felt the disturbance but did not know at the time of the occurrence that an earthquake $\underline{\text { had taken place. }}$

\section{Battleford Saskatchewan Herald May 221909}

About 9:15 p.m. Saturday Battleford was shaken by an earthquake. Dishes rattled and houses shook but no damage was done.

Canora Advertiser May 201909

\section{EARTHQUAKE SHOCK HITS WESTERN CANADA}

\section{General Alarm Prevails Over Unprecedented Occurrence - Buildings Swayed Perceptibly - No Damage Resulted}

An earthquake shock was distinctly felt in Canora Saturday night about 10.15 and was general throughout the prairie provinces. No serious damage is reported from any point but considerable alarm was in evidence at the unprecedented antics of old mother earth so far inland, where quakes are entirely unlooked for. There were very few in town who did not notice the disturbance. Walls cracked and window blinds swayed perceptibly, dishes, window panes and doors rattled and a rumbling noise was heard. Some thought it was a train and were difficult to persuade that it was a real earthquake that hit the pastoral solitudes of the prairies. Others experienced a sort of sea-sickness during the brief period of five or six seconds which the heaving and trembling lasted, but scarcely anyone reached a conclusion as to the cause before the shock was at an end. A customer in one of the stores in town thought the shelves were about to break down with the weight of the goods. One woman was found crying when her husband arrived home shortly after the disturbance. She was about to retire for the night she said when the bed began shaking and she concluded there was a man under it.

Winnipeg, May 16 - Earthquake shocks varying in intensity were felt all through the Canadian prairie west, at about 10.20 central time on Saturday evening, in most places rattling dishes, banging doors and shaking windows, while at several points people were driven in alarm out of doors. At Wolseley the well of the electric light plant caved in just before the shock was felt, and the town was plunged into darkness. Other places report cracked plaster; but that appears to be the sum of the damage done.

The shock was very light in this city but was distinctly felt at Selkirk on Lake Winnipeg and from there disturbance was noted at scattered points for a thousand miles west across the prairie. Shocks appear to have been most severe in the heavy "gumbo" country of Saskatchewan, along the main line of the Canadian Pacific; but they were felt as far north as Prince Albert. It is the first time in known history that earthquake shocks have visited the Red River or the Saskatchewan Valley, and Prof. Frank Allen, Ph. D., of Manitoba University, said tonight that they might never recur.

He attributes the disturbance to a wave or echo of serious earthquakes in Southern America or the Central Pacific, and holds that the vibration thus caused has followed the chord of a circle, coming out in the Canadian Prairie. 
He points out that the last earthquake on record was noticed at first in the observatories of western Europe, and it was some weeks before it became known that the disturbance actually took place in the barbarous region of northern India and Persia. He thus thinks that presently information will come to hand of very considerable upheavals in the southern part of the continent, or in the waters of the Pacific.

Prof. Allen is reassuring regarding the future, so far as the prairie is concerned. There is no evidence that the region was ever visited by an earthquake in historical times, or at least no marks of such have been left. This section is a long distance from the coasts where earthquakes usually occur. Besides the fact that they lie out of the prairie foundations is distinctly against such a thing. The rock layers are horizontal, whereas it is known that great earthquakes occur where the rock layers run down towards the earth centre at seventy, eighty or ninety degrees. These sometimes slip against each other, casing a big subsidence, and such is now known to have been the case at San Francisco. On the prairie, where the the rock layers are horizontal, earthquakes are practically impossible, and people will be reassured to know that it is quite possible that the prairie country may never again get such a jar.

\section{Craik Weekly News May 201909}

\section{EARTHQUAKE FELT HERE}

\section{Heavy Earthquake Shock Last Saturday Night Was Visibly Felt Throughout This Section}

\section{Buildings Swayed and Rocked But No Damage Reported--People Terribly Frightened.}

The earthquake shock which visited western Canada last Saturday night was visibly felt throughout this locality. Buildings rocked and swayed and in many cases the inmates rushed into the street in great alarm. The shock occurred at about 9:30 p.m. and lasted about twenty seconds.

The shock was general throughout the prairie provinces from Winnipeg west. But little damage has been reported and to trace given as to the origin or starting place of the disturbance.

This is the first time on record that western Canada has been visited by an earthquake shock, and as earthquake shocks are practically impossible in a prairie country it is quite possible this country may never again get such a shaking up.

\section{Cupar Herald \& North Qu'Appelle Chronicle May 191909}

Some sensation was felt by the residents within some ten miles radius of the Post Office on Saturday night last. Shortly after nine o'clock kettles, furniture, etc. started dancing and everyone experienced the unpleasant sensation of the ground shaking. There is no doubt that we were visited by an earth quake shock which lasted several seconds.

\section{Kamsack Times May 211909}

\section{Earthquake Shock}

This place was visited by a tremor of the earth about 10:15 on Saturday evening last. The sky was quite clear and there was no indication of disturbances, but shortly after 10 o'clock a distinct tremor was felt by many of the residents. The shock lasted not more than five seconds but was sufficiently clear to cause some who experienced it to 
leave their sets and go to the door, thinking a wind storm was approaching, others who were in bed sat up to see if they were awake.

In some cases children who were in bed awoke in alarm and ran to their parents. One man declared he felt it for five or ten minutes. While in the Stony Creek district it was quite distinct shortly after 10, in some houses the windows rattled. The shock was not as severe here as in other parts of the province.

As an aftermath to the tremor on Sunday evening between 8 and 9 o'clock a brilliant meteor was seen passing across the sky to the west being visible for a few seconds.

\section{A Tremor}

"It's a sure sign of a dry summer." - Old Resident.

\section{Maple Creek News May 201909}

\section{Earthquake Shock at Maple Creek}

On Saturday evening at 9:20 the town was shaken by an earthquake shock for at least twenty seconds, making dishes rattle, chandeliers swing, and creating general consternation.

Such an unheard of thing as an earthquake on the prairies dumfounded many but very reassuring explanations are made by scientific men already. While there was a general movement to the street, others who were in small frame buildings imagined a high wind had sprung up suddenly, shaking the building, and were much surprised when they went out that a dead calm prevailed.

Nearly every store in town was vacated by customers and clerks alike, the swaying of the buildings and the swinging to and fro of suspended articles betokening to all that something out of the ordinary business routine was taking place. Reports from the north country indicate that the shock was felt at least for twenty miles in that direction, one person stating that a heavy wind sprang up immediately after, although this was not experienced in town. People walking along the sidewalks apparently never felt the shock. As far as we c_.... has been no damage....ception of one or...ing and the plast... one with slight...brickwork, in wh... cracks have mad... ance.

Felt all Throug...

Earthquake sho... intensity wer felt... Canadian prairie.. 10.20, central t... evening. In mo... was a rattling of ....ing of doors and ... dows, while at... people were drive... of doors.

At Wolsley the.. tric plant ca.. fore the shock wa... town was plunge... Other places repo..ter, but that app... sum of the dama... shock was very li... but was distinctly ... on Lake Winni... there the disturba... at scattered point... west across the p...

Shocks appear... most severe in th... be" country of... along the main li... Pacific railway, but... as far north as Prince Albert. It is the first time in known history that earthquake shocks have visited the Red river and Saskatchewan valleys, and Prof. Frank Allen, Ph. D., of Manitoba university, said on Sunday that they might never recur. He attributed the disturbance to a wave of a series of earthquakes in Southern America or the central Pacific, and holds that the vibration this called has followed the chord of circle coming out in the Canadian prairies. He points out that the last earthquake on record was noticed at first in the observatory of western Europe and it was some weeks before it became known that the disturbance actually took place in the barbarous regions of northern India and Persia. He thus thinks that presently information will come to hand of very considerable upheavals in the southern part of the continent or in the waters of the Pacific.

Prof. Allen is reassuring regarding the future so far as the prairie is concerned. There is no evidence that this region was ever visited by an earthquake in historical times, or at least marks of such have never been left. This section is a long distance from the coast, where earthquakes usually occur. Besides this the lie out of the prairie foundations is distinctly against such a thing. The rock layers are horizontal, whereas it is known that great earthquakes occur only where the rock layers run down towards the earth centre at 70, 80, or 90 degrees. These sometimes slip against each other, causing a big subsidence, and such is now known to have been the case in San Francisco. On the prairie, where the rock layers are horizontal, earthquakes are practically impossible, and people will be reassured to know that it is quite possible the prairie country may never again get such a jar. 


\title{
Milestone Mail May 211909
}

\section{MILESTONE HAS EARTHQUKE SHOCK}

\section{Disturbance Lasts About One and a Half Minutes - No Damage Done}

Saturday evening last, about twenty minutes after nine o'clock the people of Milestone and district experienced a real earthquake. A slight one to be sure, without damage being done, but the real article nevertheless. Preceded by a rush of wind as the only warning it came upon is as a great surprise. Building were jarred slightly and in the hardware stores the tea-pots and tinware rattled considerably. Soon groups of excited people gathered together on the street and in their homes to discuss the phenomena of an earthquake coming to Milestone. Some were even so disturbed and disquieted they could not sleep fearing another and perhaps more serious visit of the quake. To many this was their first experience of such a thing and the impression so suddenly made will not soon leave the mind.

It being on Saturday evening it was a case of waiting until Monday, papers for further information though it was known through other sources that it was general over the three prairie provinces as far east as Winnipeg. Many feared that the daily papers on Monday would tell of serious consequences somewhere, but the only part where anything of importance occurred was in certain parts of Montana and North Dakota, and at this writing nothing positive is known regarding the source of the earthquake. We await what science will tell us about it.

The inhabitants of Wilcox were quite excited for awhile Saturday night about 9.20 o'clock when a perceptible shock was felt by those who were indoors at the time. Windows rattled and things were shaken up generally, especially in the hardware stores where tin pans etc. danced a lively jig. Dishes rattled in cupboards and different thoughts as to the cause flashed through the minds of people, causing great excitement for a time. The shock was general though throughout the western provinces and the north western states but the real source has not yet been located but will be known very probably ere this article goes to press. It is thought to be an earthquake somewhere in South America.

Note: Only Minto I can find is in Manitoba. description here fits the one from the "Minto Riverside Review" in the Manitoba newspapers so this is likely a Manitoba Newspaper in the Saskatchewan archives.

\section{Minto Packet May 201909}

Very few recognized the earthquake on Saturday evening, but quite a number have since recalled the peculiar tremor. Hugh McMillan was struck with the vibration of his house, something he never experienced before, but paid no attention to it, while R.O. Morrow heard a noise resembling a rig passing over the bridge near his place. Not being familiar with earthquakes the people are excusable for not paying it due homage.

Moose Jaw Evening Times May 171909

\section{SATURDAY'S SEISMIC DISTURBANCE HAS ASTOUNDED SCIENTIFIC WORLD}

\author{
Such a Thing Has Never Occurred Before in Prairie West and May Never Occur Again - Disturbance Recorded \\ Over Wide Territory - No Very Serious Damage Reported - Shock Locally Lasted About Thirty-five Seconds - \\ Felt in Montana.
}

Several Persons who were never known to move fast before hit a clip in getting out of buildings about 9:20 Saturday evening that would have done justice to a championship sprinter; several others, it is said, were seen in devout 
postures for the first time. The cause of all this that was so unusual, was an earthquake shock, not very great, perhaps, compared to those that occur in the volcano belts, but a considerable disturbance for these flat old prairies that were never known to move before. It was a novel experience for the people of Moose Jaw and many amusing stories are told of the behaviour of different persons when the shake took place.

It is in the unusual character of the event and the stories of the effects produced that interest chiefly centres. No damage was done though in some cases it is reported that plaster was cracked and pictures fell. The desturbance lasted about 35 seconds.

When buildings started to shake a great many attributed it to wind, but soon discovered themselves to be in error at the unusual vigor of the movement of the building. In one down town office a number of employees were sitting at work. All looked up enquiringly when desks commenced to display a tendency to take a walk across the floor. It was somewhat uncanny and all were awe-struck while faces begun to blanche. Finally one of the workers said "Earthquake." Then how they did beat it! Any they couldn't be blamed for one associates earthquakes with tumbling masonry, etc. So out of reach of falling walls and roofs all hastened.

The experience in this place was duplicated in many others, and the streets soon contained an excited lot of people.

In the third stories of down town buildings, the quake was probably most felt. There was exodus in deciddedly quick time from the Moose Jaw Club.

On the other hand the disturbance was not noticed at all by many on the streets.

The city hall shook mightedly during the disturbance. One of the city officials was at his desk when the fun began. At first he merely wondered, then he walked to the window and got it open for a hasty escape if another jolt came. The firemen, in their rooms at the rear, left the building. Someone was heard to express regret that the dear old municipal building had not fallen down, provided it was empty at the time.

A man who was in the second story of a down town building gives an interesting description of his experience. He was in a room with two others. He noticed things commencing to shaken but as the others paid no attention he thought he was simply attached by dizziness. He gripped his chair tighter and said nothing. Finally the disturbance became so marked that all noticed. First they thought it was a piano being moved on the ground floor. Then, the truth dawned upon them. The first tendency was to rush downstairs, but that certainly would not be advisable if the building were to collapse, so preparation was made for exit via a window. Happily this was not necessary, however.

In the residential districts many women were alone at the time and they were nothing short of terrified. One lady got all her jewelry and money together ready to rush to safety with such of her valuables as could be easily carried. Many another asked Divine protection.

One man told the Times an amusing incident in connection with the affair. His two young children were just getting into bed at the time. One said;

"Here, quit shaking the bed"

"I'm not, you're shaking it yourself," was the reply

"I wish I could describe the impression I felt," said a gentleman at whose home pictures were made to fall. "But at any rate I am glad to have had it."

A farmer from the north of the city came into the Times office to tell of a remarkable disturbance that was felt in the district where he lives.

Winnipeg, May 17 - That it was safe at least from earthquakes has been the fixed idea of the Canadian prairie west until Saturday evening last, when seismic disturbances were recorded over practically a thousand miles of territory, from the east to the ranching country of Southern Alberta, lying under the shadows of the Rockies and running from the heart of the State of Montana up north so far as the telegraphic wires have been carried. The shock appears to have been most severe on the main line of the Canadian Pacific between Brandon and Medicine Hat, but without recording instruments available the comparative severity at best is but guess-work and it is noteworthy that the larger centres report the worst disturbance, apparently because the shocks were felt more fully in high buildings. In Brandon temporary damage was done to the lighting plant and the same occurred at Wolseley, where the well of the electric light works caved in just before the shock, plunging the town into darkness. At Grenfell the shock was so severe that horses travelling on the road had difficulty in keeping their feet. At Saskatoon, Regina, Moose Jaw, Medicine Hat, and many other points people rushed wildly out of their homes, expecting the worst to follow, and it is reported in at least one case that they had expected that the end of the world had come. Curious, too, is the report from Regina, that the buildings most shaken there was the best constructed, being of steel and reinforced concrete, while flimsier buildings, with perhaps more give and take withstood the shock well. Ranchers in the neighbourhood of Medicine Hat, thought the quake was due to a fearful explosion of gun cotton there, while in several cases rumbling as of thunder was reported to have immediately preceded the shock which generally lasted twenty seconds. The shocks occurred about 10.20 central time, though one local report says a final shock was felt about midnight. 
It is not too much to say that the event has astounded the whole world. Nothing else is talked about. Professor Allen, of Manitoba University encourages the belief that it has never happened and may never again.

\section{At Indian Head}

Indian Head, Sask., May 17 - Two distinct earthquake shocks were felt about 9.18 last night, lasting about fifteen seconds. The first shock was a tremor, but the second was sufficiently severe to move the content of houses and stores. The buildings moved perceptibly.

\section{Felt in Montana.}

Glendive, Mont., May 17 - At 9.16 o'clock Sat. evening Glendive felt a very perceptible seismic disturbance. It seemed to be worse in some portion of the country than in others. A number of men gathered in the Masonic temple rushed from the building believing it was about to fall. Dishes rattled in the pantries. The shock lasted probably for two or three seconds, with unusual rapid vibrations. It was first thought that a heavy wind was approaching, and that a cyclone had struck town. According to telephone reports received here the disturbance was of wide extent. It was felt in Forsyth, west of here, and at Dickinson, N.D., where it is reported to have been very severe. Later reports received by train dispatchers here indicate that the strongest disturbance extended from here to Dickinson. East of that point it was very light. The town of Glasgow on the Great Northen was badly shaken. Later reports from the operator at Fryburg, N.D., says the building was badly shaken. So far as known the Northern Pacific tracks have not suffered.

\section{Quite General.}

Great Falls, Mont., May 17 - An earthquake shock was felt here Sat. night. It was also felt at Choteau, Havre, Wagner, and other points showing that it prevailed generally over northern Montana. While no serious damage was done, the shock was sufficient to thow things from the shelves.

\section{Wall Thrown Down.}

Helena, Mont., - At 9.45 o'clock Saturday night an earthquake shock lasting several seconds was felt here. The only damage reported is that of a residence, where the front retaining wall was thrown down. The wall was ten feet high, and two feet thick.

Toronto, May 17 - The seismograph at Toronto observatory registered a slight movement at eleven hours twenty minutes Saturday evening, which would correspond to nine hours twenty-seven minutes in the western provinces. A strong earthquake was also recorded this morning at three hours, twelve decimal minutes, lasting an hour and thirty-two minutes. Large waves were recorded at three hours, decimal five minutes, continuing about ten minutes. The seismography of the disturbances is four million-meters, and the estimated distance of the earthquake from Toronto is seven thousand even hundred and fifty kilometres.

\section{Director Surprised.}

Toronto, May 17 - "Must have been quite a movement," said Director Stuperd of the observatory. Our record is so slight that there is no hopes of a movement to give us any indication of where the earthquake was. Western Canada is an extremely unlikely place for an earthquake therefore this one comes as quite a surprise."

\section{Record at Ottawa}

Ottawa, May 18 - An examination of the seismograph at the Dominion observatory this morning showed a record of a distant earthquake yesterday at 3 hours 3 dot 17. The disturbance continued for two hours according to the seismograph.

\section{Slight at Calgary.}

Despatches from Montreal and Vancouver state that no earthquake shocks were felt at either place. There was a slight vibration noticed by some at Calgary but it was given no thought to. In fact but for the presence of some Californians who were earthquake experts Calgary would not have known that a tremor had occurred. 


\section{Qu'Appelle Progress May 201909}

\section{The Earth Trembled}

\section{First Recorded Earthquake in Prairie Provinces}

\section{No Damage in Qu'Appelle}

The prairie provinces had a unique though scarcely pleasant experience on Saturday night last. Between 10.19 and 10.20 p.m., fast time, a distinct earthquake was felt. Houses swayed, doors rattled, crockery and plaster fell and other signs intimated that the earth was in the throes of a convulsion. In some places it is claimed that a second shock was felt at midnight but not severe as the first.

At Wolesley the well of the electric plant caved in just before the shock was felt and the town was plunged in darkness. Many other places report experiencing the disturbance but no serious damage.

Most of the residents of Qu'Appelle and district were made aware of the strange phenomenon, some who had retired being awakened by the shaking of their beds. All sorts of theories were advanced as to the cause of the commotion but not until they had conversed with others could the majority believe that the cause lay in the earth itself.

C. E. Hill's house and kitchen were shaken apart showing a crack between of about one inch.

Thus far no news can be gleaned as to where the centre of the disturbance was. At first it was supposed the trouble started in central or South America but the fact that the shock was not felt in the Southern States precludes this theory. Another scientist claims it arose from a dislocation of rock strata in the Rockies, either in British Columbia or south of the line. This country is outside the volcanic area and may never experience another shock.

\section{FORT QU'APPELLE.}

Most of the residents here were quite alarmed at the earthquake shock which occurred on Saturday evening, and we were relieved to find later that nothing serious had taken place in other parts of the country.

\section{$\underline{\text { Regina Daily Standard May } 171909}$}

\section{SHOCK REGISTERED AT OBSERVATORIES}

Toronto Seismograph Showed Slight Movement Which Disturbed the West.

\section{NO REPORTS OF DAMAGE RECEIVED}

\section{Unlikely the Large Quake had Struck and Habited Portion of the Earth.}

Toronto, May 17 - The seismograph at Toronto observatory registered a slight movement which would correspond with the shock felt through western Canada. There is no record of any serious vibrations and it is not likely that any material damage has been done.

Buffalo, May 17 - Up to the present time the Associated Press has no report of earthquake damage, and it is likely that if the shock felt in western Canada on Saturday night is the tail end of some greater quake, it has occurred in some uninhabited region and no lives will be lost.

\section{No Sunday Record.}

Toronto, Ont., May 17 - Yesterday being Sunday, the seismograph at the government conservatory here was not examined for a record of the earth tremor. Official despatch from Qu'Appelle to the observatory says: "A slight earthquake shock was felt at 9.30 last night." R.F. Stupart the observatory director, says he cannot remember a seismic disturbance ever occurring in the northwest region before and is much surprised. The seismograph record will be examined to-morrow.

Ottawa, Ont., May 170 On account of the day being Sunday, no seismograph records were developed at the Dominion observatory, and consequently it will not be known until tomorrow if the earthquake shock reported from the west was recorded here.

\section{Felt in Winnipeg.}


Winnipeg, Man., May 17 - For the first time which history has ever recorded such an event, a distinct earthquake shock occurred Saturday night throughout a large portion of western Canada. It appears to have extended across the whole of Manitoba and Saskatchewan and throughout southern Alberta. From some points too, shocks were reported within a few seconds intervals, while at others there was only one tremor felt. No damage was done so far as has yet been learned, but much interest has been aroused by the experience of a phenomenon from which the northern part of the American continent has hitherto been supposed to be immune.

In Winnipeg only one shock was felt. It took place at 10:17 p.m. and lasted only a few seconds. It was apparently not perceptible to the majority of people on the streets, nor to those who happened to be on ground floors of buildings in the city. On the upper floors. However, the shaking was quite pronounced.

The shocks were worst from Moosomin to Moose Jaw and from Weyburn in the south to Yorkton in the north.

The occurrence of an earthquake in the central plains of North America arouses at first only a feeling of astonishment. If there is any portion of the earth's surface which might be considered immune from earthquakes, it would certainly be those plains with their enormous encumbent sapping of sedimentary rock.

Earthquakes are intimately connected with volcanoes, they appear to be co-ordinate manifeste of the same similar subteranena forces. But earthquakes profect their tremors to enormous distances from the focus of the disturbance. Where the originative shock took place, how great it was, and by what extraordinary diviation from the beaten track it manifested itself in tremors here may never become known.

But there must have been a most generous explosion somewhere unless the tremor was caused by some mechanical dislocation of rock strata which is barely possible, but not likely.

\section{The Shock in Regina.}

In Regina the shock was felt quite distinctly in some portions of the city. On the ground floor of a house it was hardly perceptible, differing little from the vibration caused by trains shunting or a wagon driven swiftly over the pavement. In the top floors of the tenement and office blocks, however, the swaying was quite noticeable and spread considerable fear among the residents.

In the stores the shock was hardly noticeable. In the Glasgow house, some felt the vibration and wondered what it was while in the McCarthy block, the building was shaken so that all within realised something was happening. In the Regina Trading company block it was not noticed on the ground floor, but in the upper stories, quite a swaying motion was experienced.

So far as can be learned, no damage whatever was caused by the earthquake. Here in the city the shock was so slight that beyond giving the people a severe fright, it left no effects. On the streets it was not noticeable at all.

\section{$\underline{\text { Regina Morning Leader }}$}

May 17, 1909

Note that the microfilm for this newspaper from the archive was very badly scratched and that much of the description of effects in Regina is unreadable, however most of the descriptions of the surrounding towns are readable (with some difficulty).

Valley Town was Shaken

From Our Own Correspondent

LUMSDEN May 16 - Considerable excitement and alarm was occasioned (?)...... last night by severe earthquake shocks. ....All the buildings in the town felt(?) the shock which occurred about 9:15(?) causing people to run out into(?) the street in great(?) alarm. The shock was.............to rattle crockery.... and ......furniture. ................ The shock lasted ......30 seconds

Was bad at Disley

From Our Own Correspondent

DISLEY, Sask., May 16. -- A slight earthquake shock was distinctly felt last night about

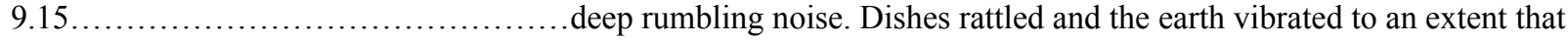
made walking difficult.......to an..........................this morning another rumbling sound was

heard.....

Shook Town Like Dynamite From Our Own Correspondent 
LANGHAM, Sask., May 16. - An earthquake shock was felt at 10.?? last night. It lasted about two minutes. Houses rocked and their contents rattled. some great explosion of dynamite had shaken the district.

Excitement at Lanigan

From Our Own Correspondent

LANIGAN, Sask., May 16. -- An earthquake shock was felt here last night at 9.12 p.m.

The people ran from their stores as the glassware began to rattle and for a time the greatest excitement prevailed.

Slight at Prince Albert

From Our Own Correspondent

PRINCE ALBERT, May 16. - the earthquake has apparently spent its force when it reached this city. ....very few people noticed it. People living in brick houses never noticed it at all, but some who happened to be upstairs in brick houses felt a slight movement of the building. At an instance ex-Mayor F.C. Baker was sitting downstairs in his residence and never felt the shock at all. His two boys who were sleeping upstairs in separate rooms got up to see who was shaking their beds. In the Mechanics Institute which is in the second floor of a framed block, Librarian B. Truscott noticed the building vibrating from east to west about 9.30. As he is a little deaf he asked two lady teachers who were in the library at the time if they felt it. They did but the movement was very slight. The shock was also felt at the residence of J. McBratney up on the hill but as far as can be learned this is the only place on the hill where the shock was felt. It was not felt at the residence of C.G. Davidson, city clerk, where the weather reports are taken. The only places the shock was felt at all was the second floor of frame buildings where quietness prevailed. The few who were in a position to feel the shock said they thought there must have been an earthquake somewhere. Reports received today confirmed their conjecture. Some people thought they felt a second shock about 11.30 p.m.

No Damage in Melfort

From Our Own Correspondent

MELFORT, Sask. May 17. -- A distinct earth shock was felt here at 9.20 last night, no damage was done.

Lasted Long at Wilcox

From Our Own Correspondent

WILCOX, Sask., May 17. -- An earthquake was felt here on Saturday at 9.16 p.m. It made the windows rattle and lasted two minutes and forty seconds.

Alarmed at Fort Qu'Appelle

From Our Own Correspondent

FORT QU'APPELLE, May 17. -- Most of the residents here were quite alarmed at the earthquake shock which occurred on Saturday evening and were relieved to find later that nothing very serious had taken place in other parts of the country.

From Our Own Correspondent

GOVAN, Sask., May 16. - Two distinct earthquake shocks were felt here last night. The second one was of considerable force causing buildings to shake and lighter articles to rattle.

Balgonie Shaken

From Our Own Correspondent

BALGONIE, May 17. -- The earthquake shock was felt here about 9.15 p.m. on Saturday evening. Some of the houses in the town were pretty badly shaken and their occupants frightened. However, no serious damage was done.

Rumbling at Aberdeen

ABERDEEN, May 17. -- A tremblor of the earth resembling an earthquake accompanied with a rumbling noise was felt at a few minutes past nine on Saturday night.

Pianos Worked Alone

ROSTHERN, Sask., May 17. - The earthquake was felt here at 9.10 on Saturday evening. Many houses were shaken. Articles inside of the buildings moved around considerably, even pianos worked. Several people in the downtown district rushed from the buildings badly frightened. 
Severe at Estevan

ESTEVAN, Sask., May 17. -- Quite a severe earthquake was felt by everyone here, although apparently no single person appears to have thought at the time that it could be an earthquake that shook the houses and made the dishes rattle. In one case here two children were awakened in bed and came downstairs to their parents with scared faces saying the bed had been moving. In T.M. Perry's hardware store the stoves and tins rattled, in another case Mr. and Mrs. L. Wright were sitting in their dining room reading when the floor apparently began to move, and they thought that the floor girders had given away, or shifted in some way, although on inspection in the cellar nothing seemed amiss.

The Empire Hotel, a solid brick building was shaken visibly, the chandeliers swaying and glasses rattled. The C.P.R. night operator was sitting at his desk working, when he thought he felt some one pulling his chair backwards, but when he looked behind there was nobody there. He then found his instruments were slightly affected and came to the conclusion that it must have been an earthquake. A number of people here appear to have been a little scared at that there will be more shocks.

Felt at Kamsack

KAMSACK, Sask., May 17. -- On Saturday night about 10.20 a distinct tremor of the earth was felt here by residents. The shock was of slight duration, lasting 5 seconds.

Regina The West May 19, 1909

\section{EARTHQUAKE SHAKES WESTERN PROVINCES}

\section{First Experience for This Part of the Continent -- Tremor Lasts From Fifteen Seconds to Half a Minute -- No Damage of Any Extent Reported -- Goods Moved on Shelved at Indian Head}

On Saturday evening last people of Regina and district were treated to a vibration, or quake of the earth, which is a new experience for this part of the world. The incident occurred between ten and twenty minutes after nine o'clock and was quite noticeable by persons in buildings. The sway of the higher buildings was quite perceptible and caused the occupants considerable alarm. People from the houses as well as the large city buildings poured out onto the streets as soon as the shock was felt. Many incidents and experiences are related. Pictures moved on the walls, electric lights flickered and many other results were noticed. So far we have been able to ascertain no damage was done in the city outside the bad scare it gave a number of people. The tremor caused in the smaller houses was at first thought to be only the passing of a heavy vehicle, or a train, in some cases it was thought that an explosion had occurred.

After the shock had subsided many experiences were greatly exaggerated.

Toronto, May 17 - The seismograph at Toronto's observatory registered a slight movement which would correspond with the shock felt through western Canada. There is no record of any serious vibration and it is not likely that any material damage has been done.

Buffalo, May 17 - Up to the present time that associated press has no report of earthquake damage, and it is likely that if the shock felt in western Canada on Saturday night is the tail end of some greater quake, it has occurred in some uninhabited region and no lives will be lost.

Winnipeg, Man., May 17 - For the first time which history has ever recorded such an event, a distinct earthquake shock occurred Saturday night throughout a large portion of western Canada. It appears to have extended across the whole of Manitoba and Saskatchewan and throughout southern Alberta. From some points two shocks were reported with a few seconds intervals, while at others there was only one tremor felt. No damage was done so far as has yet been learned, but much interest has been aroused by the experience of a phenomenon from which the northern part of the American continent hitherto been supposed to be immune.

In Winnipeg only one shock was felt. It took place at 10:17 p.m. and lasted only a few seconds. It was apparently not perceptible to the majority of people on the streets, nor to those who happened to be on the ground floors of buildings in the city. On the upper floors, however, the shaking was quite pronounced.

The shocks were worst from Moosomin to Moose Jaw and from Weyburn in the south to Yorkton in the north.

The occurrence of an earthquake in the central plains of North America arouses at first only a feeling of

astonishment. If there is any portion of the worlds surface which might be considered immune from earthquakes, it would certainly be those plains with their enormous encumbent capping of sedimentary rock. 
Earthquakes are intimately connected with volcanoes, they appear to be co-ordinate manifests of the same similar subterranean forces. But earthquakes project their tremors to enormous distances from the focus of the disturbance. Where the originative shock took place, how great it was, and by what extraordinary diviation from the beaten track it manifested itself in tremors here may never be known.

But there must have been a most generous explosion somewhere unless the tremor was caused by some mechanical dislocation of rock strata which is barely possible, but not likely.

Brandon, Man., May 16 - At 10:16 p.m. last night a most distinct earthquake was felt in the city and was followed by the others, all taking place within a minute. The inconvenience that followed was experienced most at the electric light plant. The wires from the dam seven miles west of the city where electric power is generated, were interfered with to a certain extent and caused the lights to go out later in the evening for a short time.

The C.N.R. wires in the city were very slightly affected, but did not stop the work on them.

The wires of the Great Northern Telegraph fell in the western portion of the city and were put out of commission for a time. Telephone connection was impossible for a few moments on account of no electric current and all the lights in the city went out.

People in their homes felt most distinct tremors, which caused windows, doors and other loose furniture to rattle. At the experimental farm James Murray, superintendent, reports quite severe shakes, but no damage was done. In the Fleming block one of the oldest in the city, the windows rattled very loudly. Reports from Hartney and Deloraine are to the effect that glasses in the Hotels were shaken off the bars and broken and the operators in the telegraph office state that pictures on the walls shook.

Saskatoon, May 16- For at least twenty seconds last night the citizens were aware that the city has been overtaken by some seismic disturbance. Buildings rocked, doors creaked, dishes rattled and the earth trembled -as a result frightened people turned white and looked inquiring at each other as if to ask what was coming. It was exactly 9:15 when an unusual sensation was felt by almost everybody in the city, but before they realized what had happened everything was quiet once more and with many did not dawn upon them for some time that it was a quake, such a thing never having been heard of in the prairie country within the recollection of the oldest inhabitant. Reports of similar shocks come from nearby places, but no serious damage has yet been reported though in many cases the people were seized with alarm and in some instanced rushed from their houses thinking the end of the world had come.

Nokomis, Sask., May 16 - Citizens were astonished by an earthquake shock last night which lasted about 10 seconds beginning at 9:47 p.m. The tremor was very noticeable.

Indian Head, Sask., May 16 - Two distinct earthquake shocks were felt here last night at about 9:18 o'clock, lasting about fifteen seconds. The first shock was a mere tremor but the second was so severe as to move the contents of houses and stores. Goods were shaken from the shelves in the stores. The second shock, which followed the first immediately was a distinct lift and roll, the buildings moving perceptibly.

Moosomin, Sask., May 16 - A slight earthquake shock was felt here last night about 10:15 o'clock. It seemingly covered most of the town. C.P.R. Station Agent Trenouth, who was in bed at the time, states he could feel the bed moving and noticed the building shake. It was distinctly felt in the Hotel Grand and Gosvenor hotel. The shock was felt more particularly on the second storeys where dishes were rattled and lamps set swinging. Considerable consternation prevailed amongst those who felt it most. It was not noticeable on the streets.

Qu'Appelle, Sask., May 16 - On Saturday about 10:15 p.m. Qu'Appelle experienced a slight earthquake. For about ten seconds the ground and buildings swayed with a gentle undulating motion, but no damage was done.

Lanigan, Sask., May 16-A distinct shock of earthquake lasting 30 seconds was felt in Lanigan at 9:15 Saturday evening, causing several houses to tremble and the contents to rattle violently.

Yorkton, Sask., May 16 - Last evening at 10:15 a shock was felt in every part of this district and is common talk today.

So unmistakable was it that everyone notices it, and farmers in the country were telephoning in to ask if an explosion had occurred in town. It seemed to be travelling from west to east from the fact that furniture, doors, etc., on the west side of buildings were seen to shake before those on the east side. Great alarm was felt at the time.

Moose Jaw, Sask., May 16 - A decided earthquake shock was felt at Moose Jaw last night about 9:20. The shock lasted about thirty seconds. There was no noise accompanying the shock, but buildings act-Scott, with his Worship Mayor Wil-

Maple Creek, Sask. May 16 - A heavy earthquake shock was felt here at 9:30 o'clock last night. The shock lasted only a few seconds and was felt with some force all over town, people rushing out upon the streets to learn the cause of it.

Weyburn, Sask., May 16 - A slight tremor of an earthquake passed under the town last evening at about 9:20. Though slight it was strong enough to tumble the contents from mantles to the floor. 
Wolseley, Sask., May 16 - A distinct earthquake was felt through the town here at about 9:15 last evening. In some of the business places goods hanging from ceilings were seen moving for a couple of seconds. No damage has been reported.

Saskatoon Daily Phoenix May 171909

\title{
WESTERN CANADA GIVEN A SHAKE FOR THE SPACE OF A MINUTE
}

\section{SLIGHT DISTURBANCE ON SATURDAY EVENING}

\author{
Was Felt Chiefly in Manitoba and Saskatchewan-Saskatoon Felt the Tremor for Several Seconds - No Injury \\ Reported Anywhere - Indian Head and Watrous Had it Quite Sharp - Felt North to Prince Albert
}

If an earthquake had happened people could not have been more surprised and this time the earthquake did happen and many were nervous though few if any showed downright alarm. The unusual visitation occurred at just 9:15 on Saturday night while the stores of the city and the main streets still had crowds of weekend night shoppers. Hundreds of people in town noticed nothing unusual, stores of others recalled experiencing a peculiar wobbly sensation, when they learned that an earth tremor had actually occurred, while hundreds more distinctly felt the shock and those who recognised its meaning stood in suspense at the awesomeness of the moment. In one case, two men in the law office of F.M. Brown in the National Trust Co. building, rushed downstairs and to the street while Mr. Brown felt the desk at which he was writing heave and shake under his hand, and at the same time few people passing along the street were unaware that anything was happening and in the Empire hotel across the street not a person noticed the vibration. The duration of the disturbance is variously estimated at from thirty seconds to one minute, while from Laugham it is reported to have lasted two minutes and in Winnipeg forty seconds. In Rothern the shock was severe, many people rushing from buildings and the same occurred at Regina and other points south.

Doors Rattle, Pictures Sway.

In scores of homes windows rattled, doors shook, pictures swayed on the walls and dishes and glassware clinked and clattered restlessly, as though the houses were being shaken by some giant unseen hand. In the home of F.M. Sclanders a large mirror swinging on a dressing stand turned around so that the reverse side stood where the glass had been. At the home of a retired minister in the city the shake was so severe as to cause doors to shake and rattle to such an extent that the occupants could only stand at look at one another in wonder. This was the experience to a greater or less extent in scores of homes in the city, those on the east side of the river apparently feeling the shock more than in the city proper.

At the Saskatoon club members sitting about jumped and started in wonder and alarm as the building shook. Men hesitated to call it an earthquake, but the same thought was in every mind.

\section{Quake Veterans Knew It.}

Some people recognised at once that the peculiar shaking was from no other cause than an earthquake, others suspected it but hesitated to express the word, while old quake veterans recognised the sensation.

Dr. Hugh S. Smith, for instance, who lived for years in India, knew at once what it was. The sensation was one quite commonly experienced in the parts of India where he had resided and the little irregularity on the part of old mother earth didn't alarm him very much.

People Talk It Over.

On every side on the street one hears people who noticed the unusual disturbance, recounting their individual experiences, some telling of pictures and mirrors swaying from the walls as they had never been known to do before, other noticed also the creaking and rattling of doors and windows and a few went to their doors thinking perhaps a heavy traction engine was passing by. The tremor seemed to strike the east side of houses, shaking that side first, while some say that they thought it came from the north travelling southward. That the shake north seems to be the popular view and this is corroborated in a way by a despatch from Winnipeg. It lasted there for about forty seconds and did no damage many people, as in Saskatoon, not noticing the tremor. In Saskatoon, few people who were on their feet at the time of the disturbance noticed anything unusual but most everybody sitting or even working over anything firm, such as tables, desks and counters felt the roll.

Shook the Bridge. 
On the traffic bridge a very severe shake was felt by those crossing at the time. Mr. Wm. Preston was one of these and he reports a sharp and even alarming vibration.

Mr. Austin Needham tells of a stove in his place shifted three inches by the shock. Among those who reported having felt the jar at their homes are A. H. Hanson, Fred Engen, M Isbister, J.C. Drinkle, F.M. Borland and scores of others. Jas. McKay, K.C. of Prince Albert, who is attending the supreme court session here, was in the court house library at the time and says the shock was felt very distinctly there and G.F. Johnson, court photographer, who was also in the building at the time reports the same. At the King Edward hotel a young son of the proprietor cried to his mother, who was near by, not to be shaking his bed so. No damage of any kind can be learned and it is not believed that any was done. The Bowerman building on $21^{\text {st }}$ street shook perceptibly, those in the Dominion Express Co. Office feeling the shake very distinctly.

\section{Felt in Other Places.}

Everyone was greatly surprised, never dreaming of such a thing as an earth tremor in this part of the country.

It is reported from Watrous, Sask. That plaster was cracked and shaken from the walls of some buildings there, and through Watrous word is received from Jansen, a small place east of Lanigan, that the shock was very distinct there. Conductor Waddell, of the C.P.R., who came in from the east on Sunday morning's train, said that on the train they would never have known anything was happening, but at every station along the way where the train stopped people were speaking of the earthquake, telling their experiences. Mr. Waddell thinks it was more severe further east $t$ than Saskatoon. At Lanigan, he said, a young bank man ran out of the bank building in alarm and was standing bareheaded on the street, when he was quickly joined by Bert Fleming, late of Saskatoon, who had also made a hasty exit from his hardware store when his building shook.

\section{Felt on Every Side.}

On Caswell hill and Mayfair the shock was distinctly felt. Pictures on the walls were shaken and doors rattled. One resident on Caswell hill stated that his house was shaken as if some big animal was rubbing against it and the household got a scare. In the stores on both sides of the river dishes and lamps rattled. In his house, H. Acheson felt the shock. The articles in the kitchen rattled while furniture doors in the house next door were opened. Those who had retired early heard the windows shake while the building vibrated. Mrs. W.P. Bate and other ladies on the east side are said to have got quite a scare. Mrs. Bate was upstairs in a neighbour's home at the time and it felt as if the furniture in the apartment was sliding to one side of the room. The house was shaken and articles on the walls moved. Further along Saskatchewan avenue in the Snell residence it was imagined that the bank on which the house stands was sliding into the river. Mrs. Wiggins, G.H. Power, resident engineer, was in rather a dangerous position when the shock came. He was standing on the cement wall which divides the sedimentation basin in two. While not feeling the vibration to any extent the quake caused waves to rise on the water which intimated to the engineer that something had happened. People in town from the country this morning report that the quake was felt on all sides.

Reports from out of town on the earthquake show the shock to be general over Saskatchewan and Manitoba.

\section{Felt It At Winnipeg.}

Winnipeg, May 17 - An earthquake shock, said to be the first ever recorded in western Canada, shook the three prairie provinces on Saturday night. The disturbance occurred at 10:20 p.m. central time, and was felt at the same moment from Winnipeg to Lethbridge, Alta., and from St. Paul, Minn., to Prince Albert, Sask. The shock was a very light one, however, and the only damage reported in Canada was the caving in of a well at Wolseley, Sask. In some of the northwestern states, wells also fell in, but that appears to have been the extent of the damage. The disturbance was most pronounced in the district of Indian Head, where windows rattled and heavy articles such as stoves and furniture were moved. In Winnipeg, comparatively few people noticed anything unusual and no one, as far as can be learned, felt the shock when in the street. It was in the upper stories of the less substantial buildings that the greatest motion was felt and in the operating room of the C.P.R. telegraph office, situated on the floor of the building at the corner of Main street and McDermot avenue, the shock was more noticed then anywhere else in the city. The man on duty there described the shock as a swaying motion, the building apparently swinging to and fro a distance of four or five inches.

In Winnipeg the shock appeared to travel north to south and lasted about forty seconds. No damage was done to property and a number of people failed to notice the tremor.

No reports have been received of the shock from places east of here, but practically everywhere in Manitoba and Saskatchewan records are of one or more shocks.

\section{Felt Double Quake.}

At Regina, Maple Creek, Moose Jaw and Wolsely the people rushed into the streets in alarm, but returned to their homes in time for a second tremor. In Weyburn it upset the contents of mantles and the same conditions prevailed at Indian Head where the first shock was immediately followed by a distinct heave and a roll, buildings moving perceptively. It is shown that the shocks which were also felt in Montana and Dakota were more severe in the north, so it is suggested that the centre of the disturbance is in the Arctic. 


\section{Bad Shake at Regina.}

Regina, May 17 - A very distinct earthquake shock was felt here Saturday night at 9:17 o'clock. The shock was very perceptible, shaking the buildings and frightening the residents. People who were in their houses rushed out on the street in fear. Articles of furniture were shifted from positions and ceilings and walls in several buildings were badly cracked. No serious damage was done. The shock lasted about forty seconds and few who were on the streets noticed anything wrong. People in upper stories of the houses felt it more severely and thought the buildings were falling.

Two minutes at Langham.

Langham, Sask., May 17 - An earthquake shock was felt at 9:30 here Saturday night. It lasted about two minutes.

Rosthern Gets a Scare.

Rosthern, Sask., May 17 - An earthquake shock was felt in Rosthern on Saturday evening ten minutes after nine. The quake was felt in many places around town, the higher buildings being more affected. Mr. and Mrs. A. W. Hutchinson, who have quarters in the Dawson block, two storey's, brick, thought the building was going to pieces and rushed into the street. The Queen's and Occidental hotels felt it badly, persons in the second and third stories say the buildings heaved up several inches. The post office was badly shaken. In the western portion of the town, W. Bashford and D. Gloeckler's residents were shaken. Books were almost shaken from the bookcase in Rev. Harry Ashiter's studio. Many other citizens report experiencing the quake. Furniture, dishes, and even pianos rocked considerably in many houses. Telephone and telegraph service was no interrupted at Rosthern. No damage was reported.

Felt It At Lanigan.

Lanigan, Sask., May 17 - A distinct shock of earthquake, lasting thirty seconds, was felt in Lanigan at 9.15 Saturday evening, causing several houses to tremble and contents to rattle violently.

\section{$\underline{\text { Stoughton Times May } 211909}$}

The first earthquake shock in history of Saskatchewan, as far as known, was felt on Saturday evening of last week. The shock occurred shortly after ten o'clock and was felt almost all over the entire province, as well as in Manitoba and Alberta. Locally the disturbance was quite noticeable, particularly to those who were in the upper portion of buildings at the time. No damage is reported as a result of the shock.

\section{Strassburg Mountaineer May 201909}

\section{Earthquake Shock Felt Here}

\section{Heavy "Gumbo" Country of Saskatchewan is Centre of Earthquake Shock Felt in the Prairie Provinces - Houses Sway and Contents Rattle}

Winnipeg, May 16 - Earthquake shocks varying in intensity were felt all through the Canadian prairie west at about nine twenty on Saturday evening, is most places rattling dishes banging doors and shaking windows, while at several points people were driven in alarm out of doors. At Wolseley the well of the electric plant caved in just before the shock was felt, and the town was plunged into darkness. Other places report cracked plaster; but that appears to be the sum of the damage done.

He shock was very light in this city, but was distinctly felt at Selkirk on Lake Winnipeg and from there the disturbance was noted at scattered points for a thousand miles west across the prairie. Shocks appear to have been most severe in the heavy "gumbo" country of Saskatchewan, along the main line of the Canadian Pacific; but they were felt as far north as Prince Albert. It is the first time in known history that earthquake shocks have visited the Red river or the Saskatchewan Valley, and Professor Frank Allen, Ph. D., of Manitoba University, said to-night that they might never recur.

The attributes the disturbance to a wave or echo of serious earthquakes in Southern America or the Central Pacific, and holds that the vibration thus caused has followed the chord of a circle, coming out in the Canadian prairie. He point out that the last earthquake on record was noticed at first in the observatories of Western Europe before it became known that the disturbance actually took place in the barbarous regions of Northern India and Persia. He thus 
thinks that presently information will come to hand of very considerable upheavals in the southern part of the continent, or in the waters of the Pacific.

The shock was distinctly felt here but very little damage was done. The veranda of Rev. Julius Zaetschky's house and loosened from its foundation and also the stairway inside.

\title{
Whitewood Herald May 201909
}

On Saturday evening last at about 10:20 a slight earthquake shock was felt here which is reported to have affected the three prairie provinces. The shock here was barely severe enough to be noticable but those that recognised it put it down to a heavy freight train which was passing at the moment

\section{Wolseley News May 201909}

\section{Earthquake Disturbs Western Canada}

Considerable excitement prevailed in town on Saturday night when the majority of the citizens experienced a peculiar sensation in being moved in their chairs or beds, or wherever they happened to be standing, without and effort on their own part. Floors seemed to settle down, pictures on walls, or articles hung up in the stores swung to and fro, and the feeling of those who felt the shook was as in a fainting spell or similar to sea sickness.

Those walking on the streets did not seems to notice the shock, while those indoors, with very few exceptions, were more or less disturbed. Many became excited and ran about making enquiries. After a few minutes it was learned that the shock has been felt throughout the west, and Western Canada had had an earthquake.

The daily papers of Monday in their reports said that it caused the well at the Wolseley electric light house to cave-in, but, as the well caved in fully an hour before the quake was felt, it is not certain whether that was the cause or not.

The Free Press, in part, said: - An earthquake shock, said to be the first ever shock recorded in Western Canada, shook the three prairie provinces on Saturday night. The disturbance occurred at 9.20 p.m., mountain time, and was felt at the same moment from Winnipeg to Lethbridge, Alta., and from St. Paul, Minnesota, to Prince Albert, Sask. The shock was a very light one, however, and the only damage reported in Canada was the caving in of a well at Wolseley, Sask. In some northwestern states wells also fell in, but that appears to have been the extent of the damage.

The cause of earthquakes is a subject on which scientific men speculate, rather than possess definite knowledge, but it is believed that the present disturbance has [ _ ] connection with the electrical forces of the earth and [ _ ]...blacked out... [_ ] aurora borealis, which is generally believed to be an electrical phenomenon.

Yorkton Enterprise May 221909

\section{UNEXPECTED VISIT SATURDAY NIGHT}

\author{
Slight Earthquake Shock Disturbs Some of Our Citizens About Ten O'Clock
}


Yorkton, in common with the other parts of this district and the whole of the prairie provinces was shaken by a slight earthquake shock about 10:15 last Saturday evening. Furniture and crockery were badly shaken in some houses, while in the upper flat of the hospital the patients were so alarmed that they rang the bells for the nurses. It seemed to be traveling from west to east as things shaken swaying in these directions. Although it lasted only a few seconds some women were quite alarmed. A great many people did not notice it at all and many of those who did were at a loss to understand the cause and attributed it to various other things such as explosions of dynamite in wells, on railway construction work, etc.

The following Monday the Winnipeg papers came out with scare heads and columns of matter on earthquakes and people at a distance, reading the articles would be led to believe that the West was another Messina, while as a matter of fact this is the first shock the country has ever felt. Such journalistic methods, while they may be spectacular and aid the circulation hardly conduce to the good of the country.

Many ingenious theories of the cause of the quake have since been advanced but nothing is definitely known of its real cause as yet. 


\title{
Appendix C. Newspaper accounts from Manitoban archives (Key phrases for Modified Mercalli Intensity assignments are underlined)
}

\author{
Brandon Weekly Sun May 201909
}

\section{EARTHQUAKE SHOCKS FELT}

\section{All Western Canada Feels Earth Tremble--No serious Results Reported--May Never Be Felt Again}

Western Canada was visited by a severe earthquake shock on Monday evening at about seventeen or eighteen minutes past ten. The region affected is from west of the great lakes to the foot of the Rockies.

In Brandon the shock was felt quite distinctly. In many houses articles of furniture were observed to move, and some residents were even badly scared.

As near as can be found out the first trembling of the earth was felt at about seventeen minutes after ten, when lights in many houses and places of business were noticed to flicker, ultimately going out.

No serious results, however, followed the shocks, many people, in fact, not noticing at all.

The cause of earthquakes is a subject on which scientists seem to speculate rather than possess definite knowledge, but it is believed that the present disturbance has some connection with the electrical forces of the earth and its atmosphere. On Thursday night and Friday morning the telegraph wires in the West were almost useless, and at the same time there was a particularly vivid display of the aurora borealis, which is generally believed to be an electrical phenomenon.

\section{Shock was General.}

Winnipeg, May 12 - That it was safe at least from earthquakes has been the fixed idea of the Canadian prairie west until Saturday evening last, when seismic disturbances were recorded over practically one thousand miles of territory, from the foot of Lake Winnipeg in the east to the ranching country of Southern Alberta down under the shadow of the Rockies, and running from the heart of the state of Montana to the north so far as telegraphic wires have been placed. The shock appears to have been most severe along the main line of the Canadian Pacific between Brandon and Medicine Hat, but without recording instruments the severity is at best but guess work, and a noteworthy feature is that the larger centres report the worst disturbance, apparently because these were more fully felt in high buildings.

Temporary damage was done to the light plant at Wolseley, where the well of the electric light works caved in just before the shock, plunging the town into darkness.

\section{Severe at Grenfell.}

At Grenfell the shock was so severe that horses traveling on the road had difficulty keeping their feet, while at Saskatoon, Regina, Moose Jaw, Medicine Hat, and many other points people rushed wildly out of their houses expecting more to follow, and it is reported that in at least one case they expected the end of the world had come. Curious, too, is the report from Regina that the building most shaken there was the best constructed of steel and re-inforced concrete, while flimsier buildings, with perhaps more give, withstood the shock well. Ranchers in the neighbourhood of Medicine Hat thought the quake due to a fearful explosion of guncoton stored there while in severe cases a rumbling as of thunder, was reported to have immediately preceded the shocks, which generally lasted twenty seconds, and from two to four in number, at 10.22 (seventeen central time), though one locality reports a final shock about midnight.

It is not too much to say that the event has astounded the West, as nothing else is talked about.

Professor Allen, Of Manitoba University, encourages the belief it has never happened before and may never again.

\section{Buildings Moved.}

Indian Head, Sask., May 17 - Two distinct earthquake shocks were felt about 9.18 last night, lasting about 18 seconds. The first shock was a mere tremor, but the second one was sufficiently severe to move the contents of houses and stores. Buildings moved perceptibly. 


\section{Lasts Thirty Seconds.}

Moose jaw, May 17 - A decided shock was felt about 9.v0 last night lasting about 30 seconds. buildings shook.

\section{Felt distinctly.}

Rosthein, Sask., May 17 - An earthquake shock was felt here at 9.10 Saturday evening. Many houses were shaken. Articles inside buildings moved around considerably, even to pianos. Several people in downtown districts rushed from buildings badly frightened.

\section{At Calgary.}

Calgary, May 17 - A slight vibration at 2.30 on Saturday was noted by some but given no thought to as it was like the passing of a heavy wagon on the pavement. Nothing was disturbed. Had it not been for the presence of some Californians, who were earthquake experts, Calgary wouldn't have known of it having been there.

\section{Lasted Five Seconds.}

Kamsack, Sask., May 17 - Saturday night at about 10.30 a distinct tremor of the earthquake was felt here by residents. The shock was slight in duration lasting but five seconds.

Very Slight.

Aberdeen, Sask., May 17 - A trembling of the earth resembling an earthquake, accompanied with a rumbling noise, was felt a few minutes past 10 on Saturday night.

\section{Across the Line.}

Great Falls, Mont., May 17 - This region was shaken by an earthquake early today. A heavy rain and windstorm followed.

\section{Recorded at Toronto.}

Toronto, Ont., May 17 - The seismograph at Toronto observatory registered a slight movement at eleven hours twenty-seven minutes on Saturday evening, which would correspond to nine hours twentyseven minutes in the Western provinces. A strong earthquake was also recorded this morning at 3 hours 12.8 minutes, lasting an hour and thirty-two minutes. Large waves were received at 3 hours decimal five minutes counting for two hours according to the seismograph.

\section{No Shock.}

Montreal, Que., May 17 - No trace of an earthquake shock was felt here. Coast Free From Shock.

Vancouver, May 17 - No trace of earthquake shocks here.

Western Canada Unlikely Place.

Toronto, Ont., May 17 - "There must have been quite a movement to send tremors here," said Director Stupar, of the observatory. "It likely was centered in Western Canada or the Western states, but out record here is so slight that there are no phases of the movement to give us any indication of where the earthquake was. Western Canada is an extremely unlikely place for an earthquake, and therefore this one comes as quite a surprise."

\section{Carberry Express May 201909}

\section{EARTHQUAKE THROGUHOUT THE WEST}

On Saturday night about 10.20 o'clock many people were startled by the shaking of their houses. The shaking was much more evident to those who chanced to be upstairs at the time. It lasted about half a minute and was then repeated for a shorter period. At first it was thought by many that it was a heavy freight train passing through town and it was not until Monday morning that it was actually known that Manitoba had been visited by a real earthquake. The shock was felt throughout the whole of the west and extended as far east as the lakes. No damage of any amount was reported the shaking being very slight.

This is the first time that an earthquake has ever been reported in this territory and the explanation is hard to give, scientists offer many suggestions but nothing of a definite character has been given. 


\section{Carberry News May 211909}

\section{EARTHQUAKE SHOCK}

On Saturday night about 10.20 many of our citizens were startled by the rocking of their residences. Those who were upstairs and especially those who had retired felt the shock most distinctly, may wondered what had happened. Mr Short Manager of the Union Bank felt the shock distinctly. He concluded that some of the piping in the basement had bursted and proceeded to investigate to find that everything was O.K. The shock was also felt at Wellwood where china and silverware on sideboards were made to tingle. The shock was general throughout the western provinces, at many places citizens became much alarmed, at Moose Jaw people ran out of buildings. So far no reports of damage have been received. Scientists differ in their opinions as to the cause, all are agreed that there was a upheaval somewhere along the coast lice or South America. Some of us got a scare and will be able to narrate the incident in the years to come.

\section{Carman Standard May 271909}

\section{WEST CANADA SHAKEN}

\section{FIRST EARTHQUAKE RECORDED IN PRAIRIE PROVINCES}

Disturbance Extended Over a Wide Area and is Supposed to Indicate a Great Disaster Somewhere No Serious Damage Done - Moose Jaw and Indian Head Receive Greatest Shock.

Winnipeg, Man., - Consternation was spread throughout Western Canada and the adjoining States of the Union when the whole of the vast area of country between New Ontario on the east, and Swift Current on the west, Prince Albert in the north and St. Paul on the south, was shaken by an earthquake on the night of May 16. It occurred at 10.20 o'clock and the disturbance lasted from thirty seconds to a minute, according to the locality. No damage to property has been reported, although many people in places where the shake was more severe were greatly alarmed. In Winnipeg the tremor seemed to be most pronounced in the vicinity of the Assiniboine River valley, but it was noted throughout the city. In many houses furniture was shaken.

Recollections of the horrors of the San Francisco catastrophe were recalled, and until it was finally learned that life and property throughout the country were safe there was great alarm. The C.P.R. telegraph operators, who were in communication with the western towns when the convulsion occurred, were notified that the quake was simultaneous with that in Winnipeg.

At Indian Head goods were shaken from the shelves in stores, furniture and lamps, and dishes in houses were moved and the citizens rushed to the open fearful of a terrible catastrophe. At Moose Jaw there was also a general exodus of citizens from their homes, and buildings were rocked quite perceptibly.

For two days prior to this the city had been almost isolated form the outside world, so far as telegraphic communication in concerned, through an interruption of the wire service. Terrific electrical storms also raged in several localities, but whether these outbursts had any connection with the great convulsion of nature which shook the prairie provinces cannot be known. Scientists, however, who have been consulted in the matter, declare their belief that the real force of the earthquake was not felt in this country, but rather this was but a tremor from some mighty convulsion of the earth in another section of the globe, and they expect to learn of further details of a destructive visitation. 


\section{Dauphin Herald May 201909}

\section{Did You Feel the Earthquake Shock?}

"Did you feel the earthquake shock"? is the question which meets us on every side, and great is the disappointment of those who felt it not.

The first in the history of Canada they tell us, and probably the last, so making we are most of a sensation granted us.

In a slow season, a little earthquake may be made to go a long way, conversationally. hitherto, when the thermometer registers forty below, or Manitoba is otherwise making herself as disagreeable as only she knows how and we have longed for wings to fly to California, or Sunny Italy, (or some other equally alluring land of eternal summer) some wet blanket, or other has always reminded us of the earthquakes which have so often laid waste those southern shores. "We never have earthquakes in Manitoba" they finish triumphantly: but alas! that boast is henceforth and forever denied them. - Never again - From outside points we learn that the earthquake extended across the whole of Manitoba and Saskatchewan, and southern Alberta. At some places a number of small jars occurred. The worst shock reported was in the district from Moosomin to Moose Jaw; and from Weyburn in the south, to Yorkton in the north.

There were two distinct shocks in Dauphin. First the earth quaked and then the people quaked and the second exceeded the first, for great was the quake [ thereof?_]. When the earth began to tremble at shortly after ten o'clock, on Saturday evening the pedestrians, with whom the streets lined, all evening had not yet dispersed, but those who still lingered in the highways and byways, were among those regretful ones who remained unshocked, for it was in the buildings that the force of the shock was most noticeable. From the Malcolm and Wallace blocks a number of people rushed into the street, thinking the buildings were going to collapse and the members of McMurray's or- [judge by the number of rude shocks]* chestra who were practising in the town hall also lost no time in seeking the open air. In many of the houses and stores dishes and bottles rattled on the shelves, but only in one case was anything reported as having fallen, and that occurred in one of the stores, though above the Herald office some of the ceiling plaster was dislodged. many and varied were the causes to which was ascribed the trembling, before anyone was aware that a real live earthquake had honoured us with a call. A number of "early to bed and early to risers" who had already retired, thought that some one was under their beds, and trying to get out, others scared some one of their house props had given way; many, who live in the vicinity of the railroad track, thought a train must have passed, while still others jumped to the conclusion that an explosion had taken place somewhere in the town. The sound which accompanied the quake is described by some as a rumbling and by others as a hissing sound, personally, the writer only heard what might have been the roar of the [_too blurry to read_] water had flooded the town, and was shaking the house at its foundations.

It would seem that there must be strange doings in the earth beneath to which have agitated the world in the last few years. The question is whether it is or is not a warning to us to "Cheer up, the worst is yet to come." Well! time will show.

Dauphin Press May 201909

\section{Earthquake Shocks}


Saturday night shortly after 10 o'clock two distinct earthquake shocks were experienced here. The shocks were particularly noticeable by people who were in the upper flats of their houses. Those on the streets were not aware of anything unusual happening.

The shock was general throughout the week. No damage was reported from any point.

\section{Deloraine Times May 201909}

\section{EARTHQUAKE.}

The people of the extensive western prairies have flattered themselves that whatever dangers they were subject to, earthquake was not one of them. Saturday night last, however, proved that even this claim had vanished. About 10.10 o'clock Saturday night there was all over the district east of the Rocky Mountains, more or less violent shocks felt. Although doing no damage to property, there were not a few who were a bit frightened. The shock was not strong enough to be felt in the street but those who were in bed and awake were the ones who felt the shake most plainly. In some cases and no doubt in almost every house, if notice had been taken of it, windows and dishes rattled, tables and beds shook just enough to give those who felt the shock a queer sort of feeling. Those who missed it by not being in bed are going to go to bed earlier from this time on so as to be ready for the next quake that comes along. Mr. John Morrison was one who felt the tremor and at once got busy on the phone to find out how general the vibrations were noticed. At the central phone station, it appears things looked serious, at least sufficiently so to alarm the operator, but no damage was done. In some towns in the west the shock seemed to have more decided then in Deloraine but so far as has yet been learned, there has been no damage done anywhere. It may have been one of those disturbances in the bowels of the earth that do not break through, but anyway it was enough to convince people that even the prairies may have an earthquake. People need not be alarmed about this. It is the first that has been recorded of this part of the world and if it is; and the next does not return for the same length of time, there need be no alarm felt by present settlers in the west.

\section{Lloydminster Times May 271909}

\section{WEST CANADA SHAKEN}

\section{FIRST EARTHQUAKE RECORDED IN PRAIRIE PROVINCES}

\section{Disturbance Extended Over a Wide Area and is Supposed to Indicate a Great Disturbance Somewhere - No Serious Damage Done - Moose Haw and Indian Head Receive Greatest Shock.}

Winnipeg, Man., - Consternation was spread throughout Western Canada and the adjoining States of the Union when the whole of the vast area of country between New Ontario on the east, and Swift Current on the west, Prince Albert in the north and St. Paul on the south, was shaken by an earthquake on the night of May 16. It occurred at 10.20 o'clock and the disturbance lasted from thirty seconds to a minute, according to the locality. No damage to property has been reported, although many people in places where the shake was more severe were greatly alarmed. In Winnipeg the tremor seemed to be most pronounced in the vicinity of the Assiniboine River valley, but it was noted throughout the city. In many houses furniture was shaken.

Recollections of the horrors of the San Francisco catastrophe were recalled, and until it was finally learned that life and property throughout the country were safe there was great alarm. The C.P.R. telegraph 
operators, who were in communication with the western towns when the convulsion occurred, were notified that the quake was simultaneous with that in Winnipeg.

At Indian Head goods were shaken from the shelves in stores, furniture and lamps, and dishes in houses were moved and the citizens rushed to the open fearful of a terrible catastrophe. At Moose Jaw there was also a general exodus of citizens from their homes, and buildings were rocked quite perceptibly.

For days prior to this the city had been almost isolated form the outside world, so far as telegraphic communication in concerned, through an interruption of the wire service. Terrific electrical storms also raged in several localities, but whether these outbursts had any connection with the great convulsion of nature which shook the prairie provinces cannot be known. Scientists, however, who have been consulted in the matter, declare their belief that the real force of the earthquake was not felt in this

country, but rather this was but a tremor from some mighty convulsion of the earth in another section of the globe, and they expect to learn of further details of a destructive visitation.

\section{Minnedosa Tribune May 221909}

\section{Effect of Earthquake}

W.F. McMillan who has a market garden in St. James a short way beyond Deer Lodge on the west side of Portage avenue, reports that the recent earthquake has affected his land in a remarkable degree. A piece of ground forty yards square is traversed by large cracks crossing nearly at right angles in the centre affected. The ground has been quite perceptibly pushed up in the centre much as a large piece of ice might when the thaw comes.

The ground has been thoroughly worked and seeded and the moisture in it prevents the suggestion of a mere cracking of the sun. The stratum of rock which underlies all this district is at a point about 22 feet below the surface.

The whole family were aroused from their beds by the earthquake and the children much frightened. It would be interesting to learn if any similar experience can be reported from St. James Telegram.

\section{Minto Riverside Review May 221909}

The earthquake on Saturday evening was noticed by a number in town and in the vicinity. As was the case those upstairs noticed it the most, Rev. Little's son, who was in bed, putting up a cry because his bed was shaking. Many who did not pay attention at the time have since recalled the most unusual occurrence.

Very few recognized the earthquake on Saturday evening, but quite a number have since recalled the peculiar tremor. Hugh McMillan was struck with the vibration of his house, something he never experienced before, but paid no attention to it, while R.O. Morrow heard a noise resembling a rig passing over the bridge near his place. Not being familiar with earthquakes the people are excusable for not paying it due homage. 


\section{Morden Chronicle May 201909}

Some of our people had a real shock on Saturday night, not at the hands of any pugilist, but from the fact that mother earth was in a tremor, a real earthquake. As reported in the daily papers the disturbance was general throughout the west and at some points it was quite pronounced. Though not very noticeable here it was of sufficient force to shake furniture on the upper flats, and in some instances caused quite a commotion. It was quite enough for a taste, and to cause one to hope that there will be no more kicks of that kind.

\section{Morden Empire May 201909}

\section{An Earthquake}

Perhaps the first disturbance in Morden in the shape of an earthquake occurred on Saturday night last, at about 10.15. We have made enquiries from a number of citizens and find that a very perceptible disturbance was felt. In some instances the dishes on the sideboard shelves were heard to rattle, while in other places the bed was noticed to shake. No damage was done so far as we can learn. According to the daily paper we notice that the shock was felt in the provinces of Manitoba, Saskatchewan and Alberta. In no case was there and great shock. The cause of the earthquake is not known, but so far as we can learn this is the first of the kind to happen in the west.

\section{Neepawa Press May 181909}

\section{AN EARTHQUAKE}

An earthquake shock, said to be the first ever recorded in Western Canada, shook the three prairie provinces on Saturday night. The disturbance occurred at 10:20 p.m., central time, and was felt at the same moment from Winnipeg to Lethbridge, Alta., and from St. Paul, Minnesota, to Prince Albert, Sask. The shock was a very light one, however, and the only damage reported in Canada was the caving in of a well at Wolseley, Sask. In some of the northwestern states wells also fell in, but that appears to have been the extent of the damage.

The disturbance was most pronounced on the vicinity of Indian Head, Sask., where windows rattled and heavy articles such as stoves and furniture, were moved. In Winnipeg comparatively few people noticed anything unusual, and no one, as far as can be learned, felt the shock when in the street. It was in the upper stores of less substantial buildings that the greatest motion was felt, and in the operating room of the C.P.R. telegraph offices, situated on the fourth floor of the building at the corner of Main street and McDermot avenue, the shock was more noticeable than anywhere else in the city. The men on duty there described the shock as a swaying motion, the building appatently swinging to and fro a distance of four or five inches. 
Neepawa Register May 201909

\section{Earthquake}

An earthquake shock, said to be the first ever felt in Western Canada shook the three prairie provinces on Saturday night. The shock was slight, felt more sharply at Brandon and Moosejaw than at other points from which reports were received. At Brandon the electric power was disturbed and the lights in parts of the city went out for a time and at Moosejaw people rushed into the streets alarmed at the vibration of the building. There are no seismographs in the west: the nearest is in Toronto so that no records can be had from this source. At Neepawa the shock was distinctly felt in different houses. It occurred between 10 and 11 o'clock. Dishes rattled, furniture shook and one citizen says his house swayed to and fro quite perceptibly.

The geographical formation of the province is such that scientists say there need be no fear of disastrous earthquakes here.

Portage la Prairie Evening Review May 191909

\section{EARTHQUAKE SHOCKS FELT THROUGHOUT WEST SATURDAY NIGHT}

Tremor Was Noticed in Portage la Prairie by Several People, But it Was Very Slight - At Regina, Moose Jaw and Many Other Points the Shocks Shook Buildings Severely.

\section{Western Associated Press}

Winnipeg, May 17 - That it was safe at least from earthquake has been the fixed idea of the Canadian prairie west until Saturday evening last when seismic disturbances were reported over the prairie covering one thousand miles of territory from the foot of Lake Winnipeg on the east to the ranching country of southern Alberta lying under the shadow of the Rockies and running from the heart of the state of Montana to the north so far as telegraphic wires have been carried.

The shocks appear to have been the most severe along the main line of the Canadian Pacific between Brandon and Medicine Hat but without recording instruments it is impossible to make comparisons. A noteworthy feature is that the larger centres report the worst disturbances apparently because these were more fully felt in high buildings.

In Brandon temporary damage was done to the lighting plant and the same occurred at Wolsely where the wall of the electric light works caved in just before the shock, plunging the town in darkness. At Grenfell the shock was so severe that horses travelling on the road had difficulty in keeping their feet. At Saskatoon and at Regina and Moose Jaw and many other points people rushed wildly out of their houses expecting worse to follow and it is reported in at least one case that they expected that the end of the world had come.

Curious, too, is the report from Regina that the buildings most shaken there were the best constructed being of steel and reinforced concrete, while the flimsier buildings, with perhaps more give, withstood the shock well.

Ranchers in the neighbourhood of Medicine Hat thought the quake was due to a fearful explosion of gun powder stored there, while in several cases a rumbling as of thunder was reported to have immediately preceded the shocks which generally lasted twenty seconds and were from two to four in number, at 10.22.17, central time, though one locality reports a final shock about midnight. It is not too much to say that the event has astounded the west. Nothing else is talked about.

Professor Allen, of Manitoba University, encourages the belief that it has never happened before and may never again. 
Moose Jaw, Sask., May 17 - A decided shock was felt about 9:30 last night lasting about 30 seconds. No noise accompanied the shock, but buildings shook.

Kamsack, Sask., May 17 - Saturday night about 10.20 in this district a tremor of the earth was felt here by the residers. The shock was of slight duration lasting five seconds.

Indian Head, Sask., May 17 - Two distinct earthquake shocks were felt about 9.18 last night lasting about 15 seconds. The first shock was a mere tremor, but the second was sufficiently severe to move houses and stores more perceptibly.

Locally the shocks which seem to have been pretty general throughout the west were noticed by a few persons. One gentleman who was interviewed by the Review said he felt a shock about half past ten. It lasted but a moment, however and he did not notice any other. The shock was apparently a very light one in this district.

Toronto, Ont., May 17 - "It must have been quite a movement to send tremors here," said Director Stupart of the Observatory.

"It likely was centred in Western Canada or the western States but our records here are so slight that there are no phases of the movement to give us any indication of where the earthquake was.

Western Canada is an extremely unlikely place for an earthquake, and therefore this one comes as quite a surprise.

"There is no danger from earthquakes in this country because of the homogenous composition of the underlying rock formation unless there should be a cataclysm such as formed the Rocky Mountains. It has been proved that where the Rocky Mountains now stand there was once a level plain similar to to our own prairies, and I have seen stones and fossils at Banff, 2,000 feet above the prairie level, exactly similar to those found at Stoney Mountain, Man. The Rocky Mountains were formed by gigantic upheavals, reaching from the Arctic Circle right through to South America. The four ranges of the Rockies were each formed by a separate upheaval of nature exerting force awful to contemplate." - Extract from a statement made to the Free Press by an eminent local geologist.

$\underline{\text { Roblin Messenger May } 271909}$

\section{WEST CANADA SHAKEN}

\section{FIRST EARTHQUAKE RECORDED IN PRAIRIE PROVINCES}

\section{Disturbance Extended Over a Wide Area and is Supposed to Indicate a Great Disturbance Somewhere - No Serious Damage Done - Moose Haw and Indian Head Receive Greatest Shock.}

Winnipeg, Man., - Consternation was spread throughout Western Canada and the adjoining States of the Union when the whole of the vast area of country between New Ontario on the east, and Swift Current on the west, Prince Albert in the north and St. Paul on the south, was shaken by an earthquake on the night of May 16. It occurred at 10.20 o'clock and the disturbance lasted from thirty seconds to a minute, according to the locality. No damage to property has been reported, although many people in places where the shake was more severe were greatly alarmed. In Winnipeg the tremor seemed to be most pronounced in the vicinity of the Assiniboine River valley, but it was noted throughout the city. In many houses furniture was shaken.

Recollections of the horrors of the San Francisco catastrophe were recalled, and until it was finally learned that life and property throughout the country were safe there was great alarm. The C.P.R. telegraph operators, who were in communication with the western towns when the convulsion occurred, were notified that the quake was simultaneous with that in Winnipeg.

At Indian Head goods were shaken from the shelves in stores, furniture and lamps, and dishes in houses were moved and the citizens rushed to the open fearful of a terrible catastrophe. At Moose Jaw there was also a general exodus of citizens from their homes, and buildings were rocked quite perceptibly.

For days prior to this the city had been almost isolated form the outside world, so far as telegraphic communication in concerned, through an interruption of the wire service. Terrific electrical 
storms also raged in several localities, but whether these outbursts had any connection with the great convulsion of nature which shook the prairie provinces cannot be known. Scientists, however, who have been consulted in the matter, declare their belief that the real force of the earthquake was not felt in this country, but rather this was but a tremor from some mighty convulsion of the earth in another section of the globe, and they expect to learn of further details of a destructive visitation.

\section{$\underline{\text { Selkirk Expositor May } 211909}$}

Two distinct earthquake shocks were felt here Saturday evening last at 10:30. They were of several seconds duration and about ten seconds apart. Windows rattled and residents shaken, but no damage was done.

\section{$\underline{\text { Selkirk Weekly Record May } 211909}$}

Did you feel the shock of earthquake on Saturday night last? Many Selkirk people claim that they did, and were rudely struck with the thought of the "burglar in the house" and "man under the bed," theories. But Selkirk was not the only place affected, as the shock was felt in the whole west. Scientists claim the cause to have been an upheaval in the Rocky Mountains.

\section{$\underline{\text { Swan River Star May } 201909}$}

Last Saturday about 10 p.m. several of our most respected citizens could hardly believe their senses, when chairs and tables began to dance and bric-a-brac on the bureau changed their positions. Windows rattled; and is one case a husband thought his wife was making a lot of unnecessary noise, and she thought the same of him. At Durban it is reported that someone was shook off his chair. The Bank of Commerce building there shook quite perceptibly, and along westward the tremor was more pronounced, and we came to the conclusion that we had a real live earthquake. No wonder our spring is unusual when we have such unusual visitors.

\section{Treherne Times Mav 281909}

\section{WEST CANADA SHAKEN}




\section{FIRST EARTHQUAKE RECORDED IN PRAIRIE PROVINCES}

\section{Disturbance Extended Over a Wide Area and is Supposed to Indicate a Great Disaster Somewhere - No Serious Damage Done - Moose Jaw and Indian Head Receive Greatest Shock.}

Winnipeg, Man., - Consternation was spread throughout Western Canada and the adjoining States of the Union when the whole of the vast area of country between New Ontario on the east, and Swift Current on the west, Prince Albert in the north and St. Paul on the south, was shaken by an earthquake on the night of May 16. It occurred at 10.20 o'clock and the disturbance lasted from thirty seconds to a minute, according to the locality. No damage to property has been reported, although many people in places where the shake was more severe were greatly alarmed. In Winnipeg the tremor seemed to be most pronounced in the vicinity of the Assiniboine River valley, but it was noted throughout the city. In many houses furniture was shaken.

Recollections of the horrors of the San Francisco catastrophe were recalled, and until it was finally learned that life and property throughout the country were safe there was great alarm. The C.P.R. telegraph operators, who were in communication with the western towns when the convulsion occurred, were notified that the quake was simultaneous with that in Winnipeg.

At Indian Head goods were shaken from the shelves in stores, furniture and lamps, and dishes in houses were moved and the citizens rushed to the open fearful of a terrible catastrophe. At Moose Jaw there was also a general exodus of citizens from their homes, and buildings were rocked quite perceptibly.

For two days prior to this the city had been almost isolated form the outside world, so far as telegraphic communication in concerned, through an interruption of the wire service. Terrific electrical storms also raged in several localities, but whether these outbursts had any connection with the great convulsion of nature which shook the prairie provinces cannot be known. Scientists, however, who have been consulted in the matter, declare their belief that the real force of the earthquake was not felt in this

country, but rather this was but a tremor from some mighty convulsion of the earth in another section of the globe, and they expect to learn of further details of a destructive visitation.

\section{Virden Empire Advance May 201909}

\section{EARTHQUAKE SHOCK FELT IN VIRDEN}

\section{Disturbance was quite Noticeable Shaking Contents of Houses and Other Buildings.}

On Saturday evening about 10:30 many of our citizens were surprised to feel a shock which suggested an earthquake or (as many thought) the passing in close proximity of some very heavy load. When the former was suggested the next morning by some who felt the disturbance they were ridiculed but reports substantiate their suggestion. Slight earth tremors were distinctly perceptible in Manitoba, Saskatchewan and the southern portion of Alberta.

This is the first occurrence of this kind ever recorded in the history of Western Canada and much interest has been aroused by the experience of phenomena from which the northern part pf the American continent hitherto been immune.

However, we have not heard of may damage being done except where some dishes were shaken from the shelves and broken. The fact that this is the first disturbance of the kind ever noticed in the west may be taken as an indication that it may never again be repeated and no un easiness need be felt in reference to it.

In reference to the probable cause Frederick W. Sardeson of the University of Minnesota says:

"The district affected is within the Rocky Mountain region. The shaking of the earth was undoubtedly caused by an upheaval in these mountains, which it has been discovered, are constantly rising. An upheaval of some sort probably started that long shake across the prairies. A range of mountains in Montana is, I believe, not far from the scene of the disturbance. The Black Hills are also a detached section 
from the Rockies, and any change in them might cause a shake in the country around there. Any part of the country west of the Missouri river is subject to earthquake disturbance.

"I do not agree with Prof. Allen of Manitoba University, that the earthquake is the result of one in South America. The interior of the earth is plastic solid, and the earthquake waves could not travel through it any more than they would through dough. If the wave came from South America it would have travelled along the crusts and in that case we should have felt it too."

\title{
Winnipeg Telegram May 17, 1909
}

\author{
Slight Earth Tremors Distinctly Perceptible in Manitoba, Saskatchewan and Alberta on \\ Saturday Night---Moose Jaw Felt It Most
}

\section{WINNIPEG HAD AN UNIQUE EXPERIENCE}

\section{Quake was Quite Noticeable in City, Especially On Top Floors of High Buildings and In Apartment Blocks---Noise Like Car}

\section{Observatory Records Not Yet Available}

TORONTO, Ont., May 16--- Today, being Sunday, the seismograph at the government observatory here was not examined for a record of the earth tremor. The official dispatch from the Qu'Appelle to the observatory says "A slight earthquake was felt at 9:30 last night." R.F.Stupart the observatory director, says he cannot remember a seismic disturbance ever occurring in the northwest region before and is much surprised. The seismograph record will be examined tomorrow.

OTTAWA, Ont., May 16---On account of today being Sunday, no seismograph records were developed at the Dominion observatory, and consequently, it will not be known until tomorrow if the earthquake shock reported from the west was recorded here.

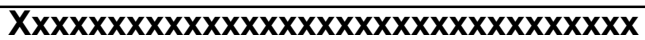

For the first time in which history has ever recorded such an event a distinct earthquake shock occurred Saturday night throughout a large portion of Western Canada. It appears to have extended across the whole of Manitoba and Saskatchewan and throughout southern Alberta. From some points, too, shocks are reported with a few seconds interval, while others there was only one tremor felt. No damage was done, so far as has yet been learned, but much interest has been aroused by the experience of a phenomenon from which the northern part of the American continent has hitherto been supposed to be immune.

In Winnipeg only one shock was felt. It took place at 10:17 p.m. and lasted only a few seconds. It was apparently not perceptible to the majority of people on the streets, nor to most of those who happened to be on the ground floors of buildings in the city. On the upper floors, however, the shaking was quite pronounced. In the C.P.R. telegraph building, for instance, the instruments were stopped for a moment, while the tables and floor swayed in a manner to be disagreeable to the operators at work. Apartment blocks felt it severely enough, although the residents in them were not able to make out at first exactly what happened. Consequently a great many of them [use?] of the telephone to inquire of "Central" what had gone wrong. They were much surprised to learn that there had been an earthquake.

\section{MANY WOULD NOT BELIEVE IT}

"Did you feel the earthquake?" was the question asked of everybody who appeared to be abroad at the hour. Those who had not felt it refused to believe it, and many were the jokes indulged in by the unbelievers at the expense of those who averred that they knew whereof they spoke. Hundreds of people, who noticed the slight shaking of their houses, put it down to the 
jarring of the street cars or gave the matter no attention. It was not until morning, in many cases, that they learned the real cause.

The severity of the shock varied considerably at different places. Some towns have nothing worse to complain of than a slight rumbling, while elsewhere articles were shaken from store shelves or house mantels, and persons were even taken off their feet by the undulating motion. In the numerous districts where two shocks are reported, the second was in every instance the stronger. The duration of the quake varied from ten seconds to as much as thirtyfive seconds. The shocks were worst in the district from Moosomin to Moose Jaw, and from Weyburn in the south to Yorkton in the north. 


\section{WHERE DISTURBANCE WAS WORST}

This is the gumbo country, a district where the soil is, for the most part, a heavy black loam. Regina, which seems to have had, perhaps, the most unpleasant experience of all, isin the heart of the district where the soil is deepest. At Regina it is recalled that when the old city well was dug some years ago, it was put down ninety feet, and the soil at the bottom was just the same as at the top. It was this class of country which was most afftected. The general movement of the shocks was from west to east, with the centre of the disturbance as described, and spreading out for hundreds of miles in all directions with gradually decreasing force.

Unfortunately the Winnipeg observatory at St. John's is not equipped with a seismograph, so that no local record of the intensity of the shock is available. As the seismic records at eh Toronto and Ottawa observatories are not developed on Sunday it was also impossible to get anything from them last night. The northern parts of all three provinces were apparently not visited with one exception, that of Prince Albert, where the quake was slightly perceptible. Lloysminister and the other points in its vicinity, however, seem to have been immune.

Despatches from several points in Montana, including Glendine, Great Falls and Helena, indicate that severe tremors were felt throughout that state extending eastward into North Dakota. At Great Falls the shock was of sufficient severity to demolish a brick wall. Dickinson, N.D., seems to have sustained a rather severe shock. Advices from Fargo and Grand Forks state that no disturbances had occurred in the vicinity of either of those cities.

\section{WILL NOT HAPPEN AGAIN}

Neither in historical nor in geologic time is anything of the kind known to have happened before to this section of the North American continent. The records of men in these parts make no mention of any previous earthquakes and the land surface shows no marks of any seismic vagaries. Moreover it is comforting to know that as it has never happened before, so also there is little probability that it will ever happen again.

The operators in the information department of the government telephone exchange, observed a distinct shaking about 10:17 p.m., but did not at first attach much importance to it until some minutes later, when subscribers in all parts of the city began to call up in an agitated way, and ask what was the matter. It seemed to have occurred to quite a number of people to telephone to the exchange. A few thought that there had been a gigantic explosion somewhere, and described to know the locality, but some of the inquirers had hit upon the true cause. There were also a considerable number of long distance calls received at the exchange, in fact, more in proportion than city calls. The reason for this is probably that while Winnipeg people may have heard the rumbling noise that accompanied the earthquake they imagined it was merely a street car. When the deep silence of the country was broken by this strange, sinister sound, people were startled and alarmed.

\section{BRANDON LIGHTS GO OUT}

BRANDON, Man., May 16,--(Special)—At 10:16 p.m. last night a most distinct earthquake shock was felt in this city and was followed by three others all taking place within a minute. The inconvenience that followed was experienced most at the electric light plant. The wires from the dam seven miles west of the city where electric power is generated, were interfered with to a certain extent and caused the lights in the city to go out later in the evening for a short time.

The C.N.R. wires in the city were very slightly affected but did not stop the work on them. The wires of the Great Northwestern telegraph fell in the west portion of the city and were put out of commission for a time. Telephone connection was impossible for a few moments on account of no electri current and all the lights in the city went out.

People in their homes felt most distinct tremors, which caused windows, doors and other furniture to rattle. At the experimental farm James Murray, superintendent, reports quite severe shakes but no damage was done. In the Fleming block one of the oldest in the city, the windows rattled very loudly. Reports from Hartney and Deloritaine are to the effect that glasses in the hotels were shaken off the bars and broken and the operators in the telephone office state that the pictures on the walls shook. 


\section{MUCH ALARM AT REGINA}

REGINA, Sask., May 16,--The sole topic of conversation in the city today is the earthquake shock last night. The shock occurred about 9:15 when the stores were crowded with Saturday night shoppers. Every building in town from the smallest shacks to the most modern fireproof office blocks appear to have been shaken. The shock was sufficiently severe to set pictures swaying and crockery rattling and disturb light pieces of furniture; while in not a few instances it is reported that walls were cracked and plaster displaced. In a few minutes the greatest excitement prevailed, people hurrying into the streets and vacating the houses and stores. The higher the building the more severe appears to have been the shock experienced by its inmates. People in the Darke block, one of the most substantially built business blocks in the city, had about the worst shaking of any. A strange feature of the quake was that it seems to have been almost unnoticed by people in the streets and out in the open.

\section{VERY DISTINCT AT MOOSE JAW}

MOOSE JAW, Sask., May 16-A very distinct earthquake shock was felt here about sixteen minutes after nine last night, lasting about thirty-five seconds. The tremor was felt all over the city and district. People rushed from their residents and stores in terror, and buildings moved perceptibly, but no damage was reported. Several people who were in the upper stories of the dwellings at the time were knocked off their feet. As no such disturbance has ever occurred here before the residents were at a loss to know the cause, and the first impression was that a violent explosion had occurred. The tremor was preceded by a loud rumbling sound. Various residents here from places where such disturbances are more or less common, say this was one of the most distinct shocks they ever experienced. Boharm, Tuxford and several other places in this district report a quake at the same time. The populace was anxious to know that cause, and wild rumors of all kinds were circulating in the city for a time.

\section{PANIC AT WEYBURN}

WEYBURN, Sask., May 16 -About 9:30 last night people in this town and district were on the border of panic as a result of the shaking and rocking of the earth, though many did not realize what was happening, It being the first quake ever experienced by the majority. Reports from outside towns tell of the same experience, and store and house windows were broken in several places. The shaking was varied in several parts as to violence.

\section{NEIGHBORING RANCHERS INQUIRE}

MEDICINE HAT, Alta., May 16 - Two shocks were felt here, one following close on the other. They were not sufficient to cause any damage but considerable fright was created as it was feared that these might be the precursors of others more violent. Numerous telephone messages were received from adjacent ranchers, who feared that a great explosion had taken place in or near the city, as it was understood that a large quantity of mitahellite was stored in the suburbs.

\section{SHOCK AT NAPINKA}

NAPINKA, Man., May 16--What it thought to have been a slight earthquake shock was felt here last night about 10:30. Several people in different parts of the town claim to have felt their buildings quiver as from a strong wind. It was comparatively calm at the time. Some claimed there was a rumbling noise at the same time, and they thought it was thunder, as it was thundering a little during the evening.

\section{FELT AT MINTO}

MINTO, Man., May 16 - (Special) - A slight shock of earthquake was felt in the village on Saturday night about 10:30. Residences shook and furniture rocked. It would appear from reports received that the quake was also experienced in other parts of the province. No damage is reported here. 


\section{IN INDIAN HEAD DISTRICT}

INDIAN HEAD, Sask., May 16 - The shock was general in the Indian Head district from Francis twenty miles south to the Qu'Appelle valley, two miles north and possibly farther north. No damage is yet reported from the country and there is none in town. The motion of the buildings was perceptible and the shock came from the southwest.

\section{HARDLY PERCEPTIBLE AT PRINCE ALBERT}

PRINCE ALBERT, Sask., May 16 - The earthquake shock was so slight that few noticed it. Only persons who happened to be upstairs in the frame buildings felt the shock at all. J.B. Truscott, librarian at the mechanics Institute which is on the top floor of the McDonald block, East Eighth street, felt the building shake from east to west. He is a little hard of hearing, which makes his other senses more acute. Two young ladies who were in the library at the time noticed the building vibrating when he called their attention to the fact. The shock was felt at the residence of ex-Mayor F.C. Baker by his two sons in their bedrooms upstairs, but Mr. Baker sitting downstairs, never noticed the shock at all. The shock was only felt upstairs in the frame buildings. In the brick buildings it was not perceptible. At the convent, which is frame, the shock was noticed by those sleeping upstairs, but at the Roman Catholic Orphanage, a brick building a few blocks away, was not felt. The shock was so slight that about 9:30 is as near the time as anybody can give.

NONE AT TWIN CITIES

FORT WILLIAM, May 16 - No earthquake shock was felt here or at Port Arthur Saturday night.

NOT FELT AT LLOYDMINSTER

LLOYDMINSTER, Sask., May 16 - No earthquake was felt here last night.

\section{Saskatoon's Shock}

SASKATOON, Sask., May 16 - For at least twenty seconds last night the citizens were aware tat the city had been overtaken by some seismic disturbance. Buildings rocked, doors creaked, dishes rattled and the earth trembled-as a result frightened people turned white and looked inquiringly at one another as if to ask what was coming. It was exactly 9:15when an unusual sensation was felt by almost everybody in the city but before they realised what had happened everything was quiet once more and with many it did not dawn upon them for some tome that it was a quake, such a thing never having been heard of in the prairie country within the recollection of the oldest in habitant. Reports of similar shocks come from nearby places, but no serious damage has yet been reported though in many cases the people were seized with alarm and in some instances rushed from their houses thinking the end of the world had come.

\section{Quite Distinct at Lethbridge}

LETHBRIDGE, Alta., May 16 - Earthquake shocks here Saturday night were quite distinct but no damage was done.

\section{Citizens Were Astonished}

NOKOMIS, Sask., May 16 - Citizens were astonished by an earthquake shock last night which lasted about forty seconds beginning at 9:17 p.m. The tremor was very noticeable.

\section{Second Shock Was Severe}

INDIAN HEAD, Sask., May 16 - Two distinct earthquake shocks were felt here last night about 9:18 o'clock lasting about fifteen seconds. The first shock was a mere tremor but the second was so severe as to move the contents of houses and stores. Goods were shaken from the shelves in the stores. The second shock, which followed the first immediately, was a distinct lift and a roll, the buildings moving perceptibly.

\section{Two Shocks at Selkirk}

SELKIRK, Man., May 16 - Two distinct earthquake shocks were felt here last night at 10:20 o'clock. They were of several seconds duration and about ten seconds apart. The tremor was sufficient to rattle windows. The shocks were apparently strongest on the banks of the river. 


\section{Household Fixtures Shaken}

ELGIN, Man., May 16 - A distinct seismic shock was felt here last night about ten minutes past ten, lasting a minute and a half or two minutes. Doors not tightly closed were jarred open and household fixtures generally were visibly shaken.

\section{Not Noticeable on Streets}

MOOSMIN, Sask., May 16 - A slight earthquake shock was felt here last night about 10:15 o'clock. It seemingly covered most of the town. C.P.R. Station Agent Trenouth, who was in bed at the time, states he could feel the bad moving and noticed the building shake. It was distinctly felt in the Hotel Grand and the Gosvenor hotel. In the houses of Mr. Elwood, Mr. Murphy and J.T. Brown on Main street, in Mr. McLean's and others on Carleton, and in Mr. Campbell's and Mr. Daniel's on Gordon, the shock was felt more particularly on the second stories where dishes were rattled and lamps were swinging. Considerable consternation prevailed among those who felt it the worst. It was not noticeable on the streets.

\section{Gentle, Undulating Motion}

QU'APPELLE, Sask., May 16 - On Saturday about 10:15 p.m. Qu'Appelle experienced a slight earthquake. For about ten seconds the ground and buildings swayed with a gentle, undulating motion, but no damage was done.

Caused House to Tremble

LANIGAN, Sask., May 16 - A distinct shock was felt in Lanigan at 9:15 Saturday evening, causing several houses to tremble and the contents to rattle violently.

\section{Thought Explosion Had Occurred}

YORKTON, Sask., May 16 - Last night at 10:15 a shock was felt in every part of this district and is common talk today. So unmistakable was it that everyone noticed it and farmers in the country were telegraphing to ask if an explosion had occurred in town. It seemed to be travelling from west to east from the fact that furniture, doors, etc. on the west side of the houses were seen and heard to shake before those on the east side. Great alarm was felt at the time.

\section{Was No Acompanying Noise}

MOOSE JAW, Sask., May 16 - A decided earthquake shock was felt at Moose Jaw last night about 9:30. The shock lasted about thirty seconds. There was no noise accompanying the shock, but buildings acted as though shaken by a high wind.

People Rushed Into Streets

MAPLE CREEK, Sask., May 16 - A heavy earthquake shock was felt here at 9:20 o'clock last night. The shock lasted for only a few seconds and was felt with the same force all over town, people rushing out upon the streets learn the cause of it.

\section{Tumbled Things to Floor}

WEYBURN, Sask., May 16 - A slight tremor as of an earthquake passed over the town last evening at about 9:30. Though slight, it was strong enough to tumble the contents on mantels on to the floor.

\section{Goods Were Seen Moving}

WOLSELEY, Sask., May 16 - A distinct quake was felt through the town here ar about 9:15 last evening. In some of the business places goods hanging from ceilings were seen moving for a couple of seconds. No damage has been reported.

\section{Severe Shock in Montana}

GLENDIVE, Mont., May 16 - At 9:16 o'clock last evening Glendive felt a very perceptible seismic disturbance. a very perceptible seismic disturbance. It seemed to be worse in some portions of the city than others. A number of men gathered in the Masonle temple rushed from the building believing it was about to fall, while dishes rattled in the pantries. The shock lasted probably for two or three seconds with unusually rapid vibrations. It was first thought that heavy winds were approaching and that the volume of a cyclone had struck the town.

According to telephone reports received the disturbance was of wide extent. It was felt at Forsythe west of here, and at Dickinson, N. D. where it is reported to have been very severe. Later reports received by train despatchers here indicate that the strongest disturbance extended from here to Dickinson. East of that point it was very light. The despatchers in the New Dickinson depot were frightened from their posts. The town of Glasgow on the Great Northern, was badly shaken. Later reports from different parts of Glendive also tell of dishes being thrown 
down and broken. The operator at Fryburg, N. D., says the building was badly shaken. So far as known the Northern Pacific tracks have not suffered.

\section{At Great Falls}

GREAT FALLS, Mont., May 16 - The earthquake shock was felt here last night. It was also felt at Choteau, Havre, Wagner and other points showing that it prevailed generally over northern Montana. While no serious damage was done, the shock was sufficient to throw things from shelves.

\section{At Helena}

HELENA, Mont., May 16 - At 9:15 o'clock last night an earthquake shock lasting several seconds was felt here. The only damage reported is that of a residence were the front retaining wall was thrown down. This wall was ten feet high and two feet thick.

\section{Winnipeg Telegram May 181909}

\section{Seismograph Recorded Second Shock Amont 3 O'clock on Sunday Morning}

Further reports as to the earthquake which occurred in the west Saturday night, confirm the impression that the disturbance was confined to the southern portion of the prairie country. Nothing was felt in Vancouver, nor anywhere on the Pacific coast. Calgary was the furthest westernly point at which there was any tremor, and even there it was just barely perceptible. At the eastern end the trouble did not spread beyond Winnipeg. No place between her and Port Arthur noticed anything and the report from Port Arthur is that nothing happened there.

Calgary and Winnipeg may therefore be taken as respectively the western and eastern ends of the earthquake, southerly it extended into Montana and northerly to Prince Albert, but at both of these extremities the shock was slight. Moose Jaw and Regina were the centre of the trouble. No damage was done anywhere. A second slight shock evidently occurred through some parts of the country early this morning. This shock was felt in Montana and was recorded on the seismograph at Toronto, but does not seem to have affected the region which was visited Saturday night.

\section{Toronto Record}

TORONTO, May 17 - The seismograph at the Toronto observatory registered a slight movement at 11.27 Saturday evening, which would correspond to 9.27 in the western provinces. A strong earthquake was also recorded this morning at 3.12 o'clock, lasting one hour and twenty minutes.

Another Shock This Morning

GREAT FALLS, Mont., May 17 - This region was shaken by another earthquake early today. A heavy rain and windstorm followed.

\section{Rushed from Buildings}

ROSTHERN, Sask., May 17 - An earthquake shock was felt about 9:10 Saturday evening. Many houses were shaken. Articles inside buildings moved around considerably. Several people in the downtown district rushed from the buildings, being badly frightened. No damage is reported.

\section{Farmers Noticed Vibration}

PORTAGE LA PRAIRIE, May 17 - Several farmers who have come into town this morning report that the rumbling and shaking of the earth were quite noticeable in the country Saturday night. Many people in town now remember experiencing a peculiar sensation for a moment, but they paid no attention to it at the time and did not realise that anything unusual had happened until reports began to come in from elsewhere. 


\section{Lasted Thirty Seconds}

GRENFELL, Sask., May 17 - A slight earthquake shock was felt here at 9.23 Saturday evening, lasting about thirty seconds. Houses shook, dishes rattles and considerable excitement prevailed for a short time. The people who were upstairs at he time noticed the disturbance more than those in the lower rooms.

\section{Distinct Shocks at Kennedy}

KENNEDY, Sask., May 17 - Shocks similar to an earthquake were distinctly felt here Saturday night at about 10.20. Several houses and stores in the vicinity were shaken. Furniture, lamps, etc., swayed considerably, startling the residents. The shock was of very short duration. No damage is reported. 


\section{Light Articles Knocked About}

MINTO, Man., May 17 - A slight earthquake shock was felt here Saturday night. A few light articles of the houses were knocked about and some alarm was caused, but no damage was done.

\section{Slight Rumbling Noise}

ABERDEEN, Sask., May 17 - A distinct trembling of the earth resembling an earthquake and accompanied with a rumbling noise, was felt here a few minutes past nine on Saturday night. No damage further than a scare is reported

\section{Not Felt At Port Arthur}

PORT ARTHUR, May 17 - No earthquake shock was felt here.

\section{No Shock at Vancouver \\ VANCOUVER, May 17 - No earthquake occurred here.}

\section{Experts Noticed Vibrations}

CALGARY, May 17 - If it had not been for outside reports and the presence in the city of Californians who are earthquake experts, Calgary would not have known there was a shock Saturday. A slight vibration at 9.30 was noticed by some but was given no thought as it was likely the passing of a heavy wagon on the pavement. Nothing was disturbed.

PEARSON, Man., May 17 - (Special) - A slight shock of earthquake was felt here on Saturday evening about 10.30 p.m. Citizens can out of their homes thinking the foundations were giving away. Reports in from the country indicate that it was felt more or less throughout the district.

MELFORT, Sask., May 17 - (Special) - A distinct earth shock was felt here at 9.20 Saturday night. No damage was done.

\section{$\underline{\text { Winnipeg Tribune May } 171909}$}

\section{WEST SHAKEN BY EARTHQUAKES}

Earth Tremors Were Felt Principally in Saskatchewan - Considerable Alarm in Public Places - Few People in Winnipeg Knew of the Shock Until Sunday - Shocks Recorded on Eastern Seismographs.

The heaving of the earth's molten interior, and the readjustment of the ito the pressure is announced to the word by earthquakes, and the Canadian prairie received its first message of this kind from Pluto on Saturday night at 10.17 o'clock. At Winnipeg, and at every point with telegraphic connection, a distinct shock was felt, lasting 12 to 16 seconds. The shock was of varying strength. Nowhere was it severe. In Winnipeg it was not noticeable on the streets, but thousands of residents who were in their houses or in tall buildings felt it.

The C.P.R. Telegraph building swayed perceptibly, enough to give the operators a momentary dizzy feeling, while they stopped working the keys. The next minute operators all over the country were reporting the shock.

The operators at the switchboard of the telephone exchange on McDermot avenue also felt the peculiar thrill. For half an hour afterwards the girls were busy answering the questions of anxious subscribers, many of whom had attributed the peculiar sensation to telephone trouble, or thought there had been an explosion somewhere.

\section{Windows Rattled.}

Of the thousands who detected the earthquake, it is safe to affirm that but an insignificant number diagnosed it for what it really was. Many houses are so attuned that the windows rattle or even the floors 
tremble, when a street car rushes past, and in the great majority of cases the trembling was attributed to this cause, though many wondered at its being more pronounced than usual.

Tom Hall, caretaker of the Scott black, who lives on the sixth floor, was preparing to retire when he felt the building trembling. Mrs. Hall was before the mirror arranging her hair, and the electric bulb hanging over the mirror swung and tapped the glass several times. Mr. Hall remarked to his wife that the street cars were going some.

In judge Walker's residence on the corner of Edmonton and Broadway. Mrs. Walker and her neice were sitting in the drawing room when the chandelier commenced to sway. A picture on the wall also slipped and Mrs. Walker's niece, who has lived in California, drew her attention to that fact.

\section{At Armstrong's Point.}

The shock appears to have been noticed very generally at Armstrong's Point, and some one has brought forward the theory of a fissure in rocky stratum corresponding with the bed of the Assiniboine. $\mathrm{H}$. N. Ruttan, city engineer, who had retired for the night, was awakened by his bed shaking. A. C. Bulling felt his bed shake and he got up to see what was the matter.

In many of the largest buildings, no tremor was observed. This list includes several of the colleges, all the hospitals, the C. N. R. station and C. N. R. telegraphs, the McIntyre block, and the Union bank.

\section{Chief Topic of Converse.}

The shock was the chief topic in Winnipeg yesterday, and almost the sole topic this morning. Those who did not feel the shock were at first sceptical and when convinced beyond doubt that the earthquake was no myth as a rule felt that they had been deprived of something that was their due.

Several persons, on learning of the earthquake remembered hearing a loud noise on Saturday night, on the west side of the city, and associated this noise with the seismic disturbance. Of course there was no noise accompanying the shock.

The observatory at St. John's did not record a shock, not being e uipped with a seismograph. The general theory is that the tremor was the vibration caused by some violent movement of the earth's crust in some distant part of the world in the recognised earthquake belt. 


\section{Toronto Expert's Comment.}

Toronto, Ont., May 17 - "It must have been quite a movement to send tremors here." said Director Stupart, of the observatory. "It likely was centered in western Canada or the western States, but our record here is so slight that there are no phases of movement to give us any indication of where the earthquake was. Western Canada is an extremely unlikely place for an earthquake, and therefore this one comes as quite a surprise."

\section{Instrument Records Two Shocks.}

Toronto, Ont., May 17 - The seismograph at the Toronto observatory registered a slight movement at 11.27 o'clock Saturday evening, which would correspond to 9.27 o'clock in the western provinces.

A strong earthquake was also recorded this morning, May 17, at 3.12 o'clock, lasting one hour and thirty-two minutes. The large waves were recorded at 3.21 o'clock, continuing about ten minutes. The semi-amplitude of the disturbance is four millimeters, and the estimated distance of the earthquake from Toronto was 7,760.1 kilometers.

A Distinct Quake.

Ottawa, May 17 - Explanation of the seismograph at the Dominion observatory this morning showed a record of a distant earthquake yesterday at 3.13.17 o'clock. The disturbace continued for two hours, according to the seismograph.

No Shock at Vancouver.

Vancouver, B.C., May 17 - There was no quake here.

None at Montreal.

Montreal, May 17 - So far no trace of any earthquake shocks here yesterday has been found. Shock Today in Montana.

Great Falls, Mont., May 17 - This region was shaken by a near earthquake shock early today. Heavy rain and a wind storm followed.

\section{At Other Points.}

Brandon, man., May 16 - At 10.16 p.m. last night a most distinct earthquake shock was felt in this city and was followed by three others, all taking place within a minute. The inconvenience that followed was experienced most at the electric light plant. The wires from the dam seven miles west of the city where electric power is generated, were interfered with to a certain extent and caused the lights to go out later in the evening for a short time.

The C. N. R. wires in the city were very slightly affected, but did not stop the work on them. The wires of the Great Northwestern Telegraph fell in the west portion of the city and were put out of commission for a time. Telephone connection was impossible for a few moments on account of no electric current and all the lights in the city went out.

People in their homes felt most distinct tremor, which caused windows, doors and other loose fixtures to rattle. At the experimental farm James Murray, superintendent, reports quite severe shakes, but no damage was done. In the Fleming block one of the oldest in the city, the windows rattled very loudly. Reports from Hartney and Deloraine are to the effect that glasses in the hotels were shaken off the bars and broken and the operators.

(Continued separate report on this page.)

\section{EARTHQUAKE 20 YEARS AGO.}

The following dispatch was taken from the Winnipeg Sun, Saturday May 11, 1889: Minneapolis, May 11 - A shock from what is supposed to be an earthquake was felt here at 3.45 this morning. The vibrations were from the northwest to the southwest. "The trembling was accompanied by a loud clap as though some heavy body had fallen on the earth."

\section{(Continued from page 1.)}

in the telephone office state that pictures on the walls shook.

Moose Jaw, Sask., May 16 - Moose Jaw thoroughly shaken by an earthquake shock at 9.15 Saturday night. Its duration was fully thirty second and the shock was felt throughout the city with more or less severity. The billiard hall on the third floor of the Union bank block was crowded at the time and the 
building shook so badly that the whole crowd rushed to the street fearing some catastrophe. The Masonic temple adjoining was also badly shaken and the occupants of the second floor were much alarmed. Late diners at restaurants quit their meal and rushed to the street. The hotels were emptied and many were the anxious enquiries as to what had happened. Buildings shook, windows rattled, opened safe doors closed with the vibration and dishes fell from the self so severe was the shock.

Regina, Sask., May 19 - The shock occurred about 9.15, when the stores were crowded with Saturday night shoppers. Every building in town appears to have been shaken. The shock was sufficiently severe to set pictures swaying and crockery rattling and disturb the light pieces of furniture while not a few instances it is reported that walls were cracked and plaster displaced. In a few minutes the greatest excitement prevailed, people hurrying into streets and vacating houses and stores. A strange feature of the quake was that it seems to have been almost unnoticed by the people in the streets and out in the open.

Saskatoon, Sask., May 16 - For at least twenty seconds last night the citizens were aware that the city had been overtaken by some seismic disturbance. The buildings rocked, doors creaked, dishes rattles and the earth trembled as a result. It was exactly 9.15 when an unusual sensation was felt by almost everybody in the city. Reports of similar shocks come from nearby places but no serious damage has yet been heard of though in many cases the people were alarmed and in some instances rushed from their houses.

Prince Albert, Sask., May 16 - Last night's earthquake shock was so slight that few noticed it. Only persons who happened to be upstairs in frame buildings felt the shock at all. J. R. Truscott, librarian at eh Mechanics institute, which is on the top floor of the McDonald block, felt the building shake from east to west. He is a little hard of hearing which makes his other senses more acute.

Grenfell, Sask., May 16 - The people of this town and of the district for miles around were thrown into a state of great excitement last night about 9 o'clock when two distinct earthquake shocks were felt preceded by a rumbling noise. Houses of all kinds were violently shaken, tables and chairs were displaced and dishes and lamps rattled. Many people rushed out of their homes fearing further shocks. Horses that were beings driven on the roads wobbled in their endeavors to keep from being thrown down.

Weyburn, Sask., May 16 - About 9.30 last night the people in the town and district were on the border of panic as a result of the shaking and rocking of the earth. Store and house windows were broken in several places.

Moosomin, Sask., May 16 - A slight earthquake shock was felt here last night and seemingly covered most of the town. C. P. R. Station Agent Trenouth, who was in bed at the time, states he could feel the bed moving and noticed the building shake. Considerable consternation prevailed. The shock was not noticeable on the streets.

Napinka, Man., May 16 - What is thought to have been a slight earthquake shock was felt here last night about 10.30 .

Deloraine, Man., May 16 - At nineteen minutes past 10 last night two distinct earthquake shocks were felt in theis town and in the vicinity round about. The shocks were violent enough to rattle doors and chinaware and were noticed most by people in the upper stories of the houses. There was a slight noise accompanying the quake, and it seemed to be a sidelong motion rather than up and down. All the farmers on the telephone exchange in the vicinity to the south and north reported having felt the shock, while it was also reported from Hartney, Melita, Lyleton and other towns in the district.

Macgregor, Man., May 16 - Shortly after 10 o'clock last night a shock supposed to have been caused by an earthquake was felt in the town, and was reported later to have been felt also six miles north of here.

Minto, man., May 16 - A distinct earthquake shock was felt in this village on Saturday night between 10.30 and 11 o'clock, many residences being shaken. 
Yorkton, Sask., May 16 - A distinct earthquake shock was felt here about 10 o'clock last night. Furniture and crockery were badly shaken in some houses. In the hospital the patients were so alarmed that they rang the bells for the nurses. Reports from Saltcoats and Wallace indicate the shock was felt there. It seems to have been general in this part of the province.

Creelman, Sask., May 16 - An earthquake shock was felt here last night about 9.30, lasting fully twenty seconds. Several small articles were dislodged in the station house.

Lethbridge, Alta., May 16 - Quite a distinct earthquake shock was felt here last evening. A number of buildings were shaken but not damaged.

Neudorf, Sask., May 16 - Two distinct vibrations of the earth were felt in this town at 10.10 lat night, causing windows to rattle.

Halbrite, Sask., May 16 - At about 9 o'clock last night a distinct earthquake shock was felt by the residents. The walls shook and the dishes rattled on the shelves. Two distinct shocks were felt with only a short interval between.

Langham, Sask., May 16 - An earthquake shock was felt here at 9.30 last night. It lasted about two minutes but caused no damage.

Swift Current, Sask., May 16 - A distinct earthquake shock was felt here last night about 9 o'clock and lasting about twenty seconds. It shook all the buildings in the town. No damage.

Alexander, Man., May 16 - Last night a few minutes before 10 o'clock a distinct earthquake shock was felt in the town. It was sufficient to cause a very slight motion to buildings.

Maple Creek, Sask., May 16 - A heavy earthquake shock was felt at 9.20 last night. The shock lasted only a few seconds and was felt all over the town. The people rushed into the streets to learn the cause of the shock.

Indian Head, Sask., May 16 - Two distinct earthquake shocks were felt here about 9 o'clock last evening and lasted about 15 seconds. The first shock was a mere tremor, but the second was severe enough to move the contents of houses and stores. Goods were shaken from the shelves in the stores, the buildings moving perceptibly.

Estavan, Sask., May 16 - Quite a severe earthquake shock was felt here last evening, causing the stoves in the hardware stores and the dishes in the kitchen cupboards to rattle. No damage was done.

Wolseley, Sask., May 16 - Wolseley was visited by an earthquake shock about 8.30 last night. The shaking was quite severe on Front and Sherbrooke streets and at the station. Shortly before the earthquake the well at the electric light works caved in suddenly, and the electric lights went out. No other damage is reported.

Qu'Appelle, Sask., May 16 - An earthquake shock was felt here last night about 9.20. The second shock was felt about midnight. Dishes were rattled.

Theodore, Sask., May 16 - A slight but distinct earthquake shock was felt here last night about 10.15. Windows rattled.

Elgin, Man., May 16 - Doors, not tightly closed, were jarred open and the household fixtures, generally, were visibly shaken here.

Virden, Man., May 16 - It shook the buildings, but no damage was done. 
Waskada, Man., May 16 - The first was quite sharpe, causing loose doors and windows to rattle. After a slight pause another shock occurred the two lasting in all about 20 seconds. No damage is reported.

Dauphin, Man., May 16 - The shocks lasted from one to three seconds. Houses rocked and in numerous cases the contents were scattered about and the people rushed into the streets. In one instance a platter fell from the wall of a building. The shock was also left in other parts of the district.

Invermay, Sask., May 16 - Nearly every person in the village noticed the effect of the shock in one way or another. Dishes on the sideboards rattled, and curtains were shaken.

McTaggart, Sask., May 16 - A number of buildings were shaken and the crockery rattled. No damage is reported.

Portage la Prairie, Man., May 16 - The earthquake tremor did not affect this city, and was not noticed so far as can be learned, except by one citizen.

Medicine hat, Alta., May 16 - Two earthquake shocks were felt here last night. The vibrations were not sufficient enough to cause any damage but considerable fright was created. Country districts reported the shock.

Lemberg, Sask., May 16 - Tw distinct shocks were felt and the buildings shook perceptibly. No damage has been reported.

\section{In the States}

Helena, Mont., May 15 - Earthquake shocks occurred here at 9.15 tonight and losted for several seconds. Great alarm has been caused throughout the city by the receipt of advices from many points to the north and south, telling of serious similar shocks which have been taking place throughout this section.

The shocks here lasted several seconds and were distinctly felt throughout the city. The older houses in the town shook violently, people rushed from their homes into the streets in wild bewilderment, and for a time it was feared that serious damage had been done.

After some time it was ascertained that the only read damage was to a residence in the better section where a retaining wall was thrown down, causing the house to shift considerably. This wall was ten feet high and two feet thick and was built of brick and masonry and was intended to withstand great pressure.

Railroad men reaching here report that the Northern Pacific tracks have suffered to a considerable extent, having been thrown up in several places for considerable distances.

In many homes the dishes rattled in the pantries, pictures were shaken from the walls and large portions of plaster dropped to the floor near the demoralized occupants.

At Dickinson, N. D., it is said that the shocks were the most severe. The despatchers in the new depot were frightened from their posts and were unable to return to their work for some time owing to the falling of a door and wall which came down with the trembling and rapid vibrations of the building.

The town of Glasgow on the Great Northern railroad was also shaken and for fully three minutes consternation reigned there. At Fryburg, N. D. , the railway station was badly shaken by shocks which lasted for two minutes, according to the reports from the telegraph operator at that place.

Rosthern, Sask., May 17 - An earthquake shock was felt at Rosthern about 9.10 o'clock Saturday evening. Many houses were shaken. Articles inside buildings were moved around considerably. Even pianos worked. Several people in the down town district rushed from the buildings, being badly frightened. No damage is reported.

Port Arthur, Ont., May 17 - No earthquake shock was felt here.

Calgary, ,May 17 - If it had not been for outside reports and the presence in the city of Californians who are earthquake experts, Calgary would never have known there was a shock Saturday. A slight vibration at 21.30 o'clock was noticed by some, but was given no though, as it was like the passing of a heavy wagon on the pavement. Nothing was disturbed. 
Rapid City, Man., May 17 - There was great excitement here Saturday night when the earthquake was felt about 10.30 o'clock. The quake was especially noticed by a sick lady who complained of the bed shaking badly. The wall of the stone stable belonging to G. N. Hindson collapsed. This is all the damage reported so far.

Frank Williams, of Seven Oaks, speaking to a Tribune reporter yesterday, said: "I certainly felt the shocks all right, and one of my objects in coming to Winnipeg today was to hear more particulars respecting it, for I feared some serious results might possibly have followed. My house is very solidly built on stone foundation, although the upper portion is of frame, and no climatic influence that I can think of could give it the severe shock which I felt. There were two successive shocks, lasting 15 or 16 seconds each, and they occurred as near as my time would indicate, at 10.15 Saturday evening.

"I had been working hard all day and thought my nerves might have been a little unstrung when I felt the first shock, but when I saw the doors fly open, I asked my wife and son if they had felt anything and they both corroborated my suspicion, having experienced distinct shaking on two occasions about the time named.

"The experience is so novel in this part of the world that I came down to Winnipeg to see if we had really been mistaken before saying anything about the matter.

Manitoba Free Press (Winnipeg) May 171909

\section{EARTHQUAKE DISTURBS WINNIPEG AND MANY PARTS OF WESTERN CANADA}

\section{POSSIBILITY OF A CATACLYSM.}

"There is no danger from earthquakes in this country because of the homogenous composition of the underlying rock formation, unless there should be a cataclysm such as formed the Rocky Mountains. It has been proved beyond a doubt that where the Rocky mountains now stand there was once a level plain similar to our own prairies, and I have seen stones and fossils at Banff, 2,000 feet above the prairie level, exactly similar to those found at Stoney Mountain, Man. The Rocky Mountains were formed by gigantic upheavals, reaching from the Arctic circle right through to South America. The four ranges of the Rockies were each formed be a separate upheaval of nature exerting a force awful to contemplate."- Extract from a statement made to the Free Press by an eminent local geologist.

\section{Slight Shock Felt in the City Shortly After Ten O'Clock Saturday Night - Tremor was noticeable Particularly in Armstrong's Point Locality and at Canadian Pacific's Telegraph Building - No Appreciable Damage Results - Indication That Seismic Phenomena Extended From Winnipeg to Lethbridge and From St. Paul to Prince Albert - Said to be the First Experienced in the Canadian West - Severe Along Northern Pacific.}

An earthquake shock, said to be the first ever recorded in Western Canada, shook the three prairie provinces on Saturday night. The disturbance occurred at 10.20 p.m., Central time, and was felt at the same moment from Winnipeg to Lethbridge, Alta., and from St. Paul, Minnesota, to Prince Albert, Sask. The shock was a very light one, however, and the only damage reported in Canada was the caving in of a well at Wolseley, Sask. In some of the northwestern states wells also fell in, but that appears to have been the extent of the damage.

The disturbance was most pronounced in the vicinity of Indian Head, Sask., where windows rattled and heavy articles, such as stoves and furniture, were moved. In Winnipeg comparatively few people noticed anything unusual, and no one, as far as can be learned, felt the shock when in the street. It was in the upper stories of the less substantial buildings that the greatest motion was felt, and in the operating room of the C.P.R. telegraph offices, situated on the fourth floor of the building at the corner of Main street and McDermot avenue, the shock was more noticeable than anywhere else in the city. The men 
on duty there describe the shock as a swaying motion, the building apparently swinging to and fro a distance of four or five inches.

\section{NOTICEABLE AT ARMSTRONG'S POINT.}

Armstrong's Point, which is close to the Assiniboine river, was the locality in which the shock was most greatly felt in the city, and it has been suggested that this is due to the fact that the river probably found its course in a gutter formed by the junction of two geological formations, between which is an unhealed fissure, leading down towards the centre of the earth.

The cause of the earthquakes is a subject on which scientific men speculate rather than possess definite knowledge, but it is believed that the present disturbance has come connection with the electrical forces of the earth and its atmosphere. On Thursday night and Friday morning the telegraph wires in the west were almost useless, and at the same time there was a particularly vivid display of the aurora borealis, which is generally believed to be an electrical phenomenon.

At the government telephone exchange in Winnipeg the tremor was felt by some of the operators, and thereafter there were frequent calls from subscribers enquiring as to the trouble.

\section{Dr. Bryce's Opinion.}

Rev. Dr. Bryce, one of the best authorities on the geology of the west, was quite at a loss, when seen by the Free Press yesterday, to explain the earthquake, unless it were a tremor caused by a big disturbance at some distant part of the world, news of which has not yet been received.

"The geological formation of this country," said Dr. Bryce, "Is such that there was no reason to expect that its former immunity from earthquakes would not be continued. There is no sign of volcanic action anywhere on the prairies, and the strata which underlie this country are so level that it can be said for certain that there has never been a severe earthquake in the thousands of centuries since their formation. This shock was a very slight one, and there is absolutely no need for alarm, because this region has always been free from seismic disturbances."

Unfortunately there is no seismograph in the city, or in the west, in fact the nearest quake recorder it at Toronto, and it is therefore impossible to say with certainty whether or not there has ever been an earthquake in western Canada before. Some twenty years ago a number of people declared that they had felt a slight tremor of the earth during the night and there was no explanation of this except that it was an earthquake shock, but no particular attention was made to the matter at the time.

It is expected that the seismographs in eastern Canada have recorded this quake, but the instruments are never examined on a Sunday, and no report can be received until to-day.

\section{In Telegraph Building}

The shock was felt with more distinctness in the C. P. R. telegraph operating room than in any other part of the city. There were nine operators on duty in the room at $10.20 \mathrm{p} . \mathrm{m}$. and all noticed the quake. The building appeared to them to sway as if in a strong wind, and seemed to move four or five inches, swinging back and forth several times. The electric lights hanging from the ceiling were also seen to swing. There were two shocks, each lasting about 15 seconds, with a period of half a minute in between. The building is an old one and easily disturbed, and this accounts for the distinctness with which the shock was felt.

One of the operators was at the time talking with the operator at Lanigan, Sask., when the latter suddenly broke off and said "There is an earthquake here", It was at the same moment that it was felt in the local office. A few moments later telegrams began to pour in from all over Saskatchewan stating that the shock had been felt and asking if it had done any damage in Winnipeg. These queries came from the west as far as Prince Albert and as far south as St. Paul and Minneapolis. Nowhere was any damage was done but dishes were heard to rattle and similar indication given of a distinct tremor of the earth.

\section{At Railway Station.}

The shock was also felt by the telegraphers at the C. P. R. station, but not so distinctly, and in the switch room at the telephone exchange some of the operators distinctly felt the stools on which they sat move. One of the girls complained of feeling a dizziness as the result of the motion, but others did not notice the shock at all.

The tremor was particularly severe in Montana and in fact was felt in the northern tier of states following the line of the Northern Pacific railway from Minneapolis to the Rockies.

\section{Resident Speak of it.}

Prominent residents of the city were disturbed by the shock. 
H. N. Ruttan, city engineer, felt the tremor quite plainly at his residence on Armstrong's Point. "I had retired for the night," he said yesterday, "and I was awakened by the shaking of the bed. It was quite distinct and it occurred between 10 and 11 o'clock.

A. C. Bulling, another Armstrong's Point resident, also felt the shock very distinctly. He had retired and felt the bed moving. It was so distinct that he got up and went downstairs to see if there was anything the matter with the house. He believes that the tremor lasted about a minute and it occurred about 10.20 o'clock.

In one home on Wellington Crescent the lady of the house noticed the tremor to such an extent that she received quite a fright. She was sitting on a box seat and felt it move with an entirely different kind of vibration form what could have been caused by passing vehicles.

Watchmen at the Eaton building state that they noticed nothing unusual at 10.20 on Saturday night. They feel sure that they would have felt any decided shake as the building was very quiet at the hour. St. Boniface hospital authorities say that there was no tremor noticed here. At Winnipeg general there were no reports of any shock.

F. B. Scott, of 595 Spence Street, experienced the shock and heard the dishes rattle in the cupboard. The shock was also felt by the residents on Polson Avenue, at the residence of Sheriff Inkster, at Kiidonan, and in almost every part of the city.

\section{GENERAL IN THE WEST}

Moose Jaw Badly Shaken - Number of Other Towns Felt Shocks.

Moose Jaw, Sask., May 18 - Moose Jaw was thoroughly shaken by an earthquake shock at 9.15 Saturday night. Its duration was fully thirty seconds and the shock was felt throughout the city with more or less severity. Pedestrians did not feel it distinctly, but occupants of buildings were greatly alarmed and rushed into the streets. The shock was felt most distinctly on Main street in the large business blocks. The billiard hall on the third floor of the Union bank block was crowded at the time and the building shook so badly that the whole crowd rushed to the street fearing some catastrophe. The Masonic temple adjoining was also badly shaken and the occupants of the second floor were much alarmed. Late diners at restaurants quit their meal and rushed to the street. The hotels were emptied and many were the anxious enquiries as to what had happened. Buildings shook, windows rattled, opened safe doors closed with the vibration and dishes fell from the shelf so severe was the shock.

The earthquake was soon all the talk and continues to be the subject of conversation. The telegraph office was soon besieged with inquiries for news as to when the chief disturbance had occurred, many believing that some great catastrophe must have occurred at the coast. Considerable relief was felt when the word cane that so far as known the shock was confined too the prairie provinces.

\section{Severe Shock at Brandon.}

Brandon, Man., May 16 - A series of three, and probably four earthquake tremors were experienced here last night shortly after 10 o'clock. Each shock was of several seconds duration, the whole series occurring within the space of a minute. The quake was distinctly felt all over the city, houses swaying and doors, furniture and crockery rattling as if following the shock of a heavy explosion. At the experimental farm the tremor was even more distinct, but no damage was done. Immediately after the occurrence the city phones were busy with inquiries and numerous cases were reported of people being awakened from their sleep. The children left their beds and ran downstairs in terror. The city rural phones were momentarily affected through the failure of the current, while a portion of the G. N. W. wires were thrown to the ground immediately west of the city.

A perceptible effect was noticeable in the electric light current throughout the city and the circuit from the dam on the Assiniboine River was deranged for a time, leaving portions of the city in darkness. Reports from the surrounding country are to the effect that the shock was more severely felt on all sides than in the city and tales of damage to windows, crockery, hanging pictures, etc., have been numerous. The exact time of the tremor appears to have been 10.17 .

\section{Shock Felt at Regina.}

Regina, Sask., May 16 - The sole topic of conversation in the city to-day is the earthquake shock last night. The shock occurred about 9.15, when the stores were crowded with Saturday night shoppers. Every building in town appears to have been shaken. The shock was sufficiently severe to set pictures swaying and crockery rattling and disturb the light pieces of furniture, while in not a few instanced it is reported that alls were cracked and plaster displaced. In a few minutes the greatest excitement prevailed, people hurrying into streets. The higher the building the more severe appears to have been the shock 
experienced by its inmates and the people in the Dark block, the most substantially built business block in the city, had about the worst shaking of any. A strange feature of the quake was that it seems to have been almost unnoticed by people in the streets and out in the open.

Saskatoon, Sask., May 16 - For at least twenty seconds last night the citizens were aware that the city had been overtaken by some seismic disturbance. The buildings rocked, doors cracked, dishes rattled and the earth trembled as a result. It was exactly 9.15 when an unusual sensation was felt by almost everybody in the city, but before they realized just what had happened everything was quiet once more and with many it did not dawn upon them for sometime that it was a quake, as such a thing has never before been heard of in the prairie country within the recollection of the oldest inhabitant. Reports of similar shocks come from nearby places but no serious damage has yet been heard of, though in many cases the people were alarmed and in some instances rushed from their houses.

Prince Albert, Sask., May 16 - Last night's earthquake shock was so slight that few noticed it. Only persons who happened to be upstairs in frame buildings felt the shock at all. J. B. Truscott, librarian at eh Mechanics institute, which is on the top floor of the McDonald block, felt the building shake from east to west. He is a little hard of hearing, which makes his other senses more acute. Two young ladies in the library at the time also noticed the building vibrating. The shock was felt at the residence of ex-Mayor Baker by his two sons in their bedroom upstairs, but Mr Baker sitting downstairs never noticed the shock at all. At the convent, which is frame, the shock was noticed by those sleeping upstairs, but at the Roman Catholic orphanage, a brick building a few blocks away, the shock was not felt.

Grenfell, Sask., May 16 - The people of this town and of the district for miles around were thrown into a state of great excitement last night about 9 o'clock when two distinct earthquake shocks were felt, preceded by a rumbling noise. Houses of all kinds were violently shaken, tables and chairs were displaced and dishes and lamps were rattled. Many people rushed out of their homes fearing further shocks. No actual damage has been reported vet. Horses that were being driven on the roads wobbled in their endeavors to keep from being thrown down.

Weyburn, Sask., May 16 - About 9.30 last night the people in the town and district were on the border of panic as a result of the shaking and rocking of the earth. Many did not realize what was happening, it being the first quake ever experienced. Reports from outside towns tell of the same experience and store and house windows were broken in several places. The shaking varied in several places as to violence.

Moosomin, Sask., May 16 - A slight earthquake shock was felt here last night and seemingly covered most of the town. C. P. R. Station Agent Trenouth, who was in bed at the time, states he could feel the bed moving and noticed the building shake. The shock was distinctly felt in the Grand and Grosevnor hotels. Messrs Murphy, Elwoods and J. T. Brown's houses on Main street, McLean's and others on Carleton, Campbell's and Daniel's on Gordon street were shaken more particularly in the second stories where dishes were rattled and lams set swinging. Considerable consternation prevailed. The shock was not noticeable on the streets.

Napinka, Man., May 16 - What is thought to have been a slight earthquake shock was felt here last night about 10.30. Several people in different parts of town claim to have felt their buildings quiver as from a strong wind, although it was comparatively calm at the time. Some claimed there was a rumbling noise at the same time, but this may have been thunder as it was thundering a little during the evening.

Deloraine, Man., May 16 - At nineteen minutes past 10 last night two distinct earthquake shocks were felt in this town and in the vicinity round about. The shocks were violent enough to rattle doors and chinaware and were noticed most by people in the upper stories of the houses. There was a slight noise accompanying the quake, and it seemed to be a sidelong motion rather than up and down. All the farmers on the telephone exchange in the vicinity to the south and north reported having felt the shock, while it was also reported from Hartney, Melita, Lyleton and other towns in the district.

Macgregor, Man., May 16 - Shortly after 10 o'clock last night a shock supposed to have been caused by an earthquake was felt in the town and was reported later to have been felt also six miles north of 
here. The tremor was strong enough to shake pictures, stoves and dishes, and was thought by those who felt it to be caused by the passing of a train. No train, however, passed at that time.

Selkirk, Man., May 16 - Two distinct earthquake shocks were felt here last night at 10.20. They were of several seconds duration and about ten seconds apart. The tremor was sufficient to rattle the windows.

Minto, Man., May 16 - A distinct earthquake shock was felt in this village on Saturday night between 10.30 and 11 o'clock, many residents being shaken. Reports from other points in the district state that the shock was felt there also.

Yorkton, Sask., May 16 - An earthquake shock was felt here about 10 o'clock last night. Furniture and crockery were badly shaken in some houses while in the upper flat of the hospital the patients were so alarmed that they rang the bells for the nurses. Reports from Saltcoats and Wallace indicate the shock was felt there. It seems to have been general in this part of the province.

Creelman, Sask., May 16 - An earthquake shock was left here last night about 9.30 lasting fully twenty seconds. Several small articles were dislodged in the station house and some of the freight in the shed was thrown down, the windows were also rattled.

Lethbridge, Alta., May 16 - Quite a distinct earthquake shock was felt here last evening. A number of buildings were shaken but not damaged.

Neudorf, Sask., May 16 - Two distinct vibrations of the earth were felt in this town at 10.10 last night, causing the windows to rattle and the people to leave their beds and hurry out into the streets. The shock was general along this branch. The vibration lasted about five seconds.

Dubue, Sask., May 16 - About 19.15 last night quite a pronounced earthquake shock was felt here. It was over one minute's duration, shaking the windows and moving the lamps. The citizens were considerably alarmed. NO damage was reported.

Halbrite, Sask., May 16 - At about 9 o'clock last night a distinct earthquake shock was felt by the residents. The walls shook and the dishes rattled on the shelves. Two distinct shocks were felt with only a short interval between.

Langham, Sask., May 16 - An earthquake shock was felt here at 9.30 last night. It lasted about two minutes, but caused no damage.

Swift Current, Sask., May 16 - A distinct earthquake shock was felt here last night about 9 o'clock and lasting about twenty seconds. It shook all the buildings in the town. NO damage is reported.

Alexander, Man., May 16 - Last night a few minutes before 10 o'clock a distinct earthquake shock was felt in the town. It was sufficient to cause a very slight motion to the buildings.

Maple Creek, Sask., May 16 - A heavy earthquake shock was felt at 9.20 last night. The shock lasted only a few seconds and was felt all over the town. The people rushed into the streets to learn the cause of the shock.

Indian Head, Sask., May 16 - Two distinct earthquake shocks were felt here about 9 o'clock last evening and lasted about 15 seconds. The first shock was a mere tremor but the second was severe enought to move the contents of houses and stores. Goods were shaken from the shelves in the stores, the buildings moving perceptibly.

Estevan, Sask., May 16 - Quite a severe earth shock was felt here last evening, causing the stoves in the hardware stores and the dishes in the kitchen cupboards to rattle. No damage was done. 
Wolseley, Sask., May 16 - Wolseley was visited by an earthquake shock about 8.30 last night. The shaking was quite severe on Front and Sherbrooke streets and at the station. Shortly before the earthquake the well at the electric light works caved in suddenly, and the electric lights went out. No other damage is reported.

Qu'Appelle, Sask., May 16 - An earthquake shock was felt here last night about 9.20 p.m. While no damage was reported the shock was sufficient to open doors, rattle dishes and in some cases to crack the plaster. The second shock was felt about midnight.

Theodore, Sask., May 16 - A slight but distinct earthquake shock was felt here last night about 10.15. It caused quite a lost of excitement for a short time. The trembling only lasted a few seconds, but long enough to rattle dishes, doors and windows in nearly every building in the town.

Elgin, Man., May 16 - A distinct seismic shock was felt here last night about ten minutes past ten lasting a minute and a half or two minutes. Doors, not tightly closed were jarred open and the household fixtures, generally, were visibly shaken.

Virden, Man., May 16 - A slight earthquake shock was felt here last night. It shook the buildings, but no damage was done.

Waskada, Man., May 16 - Two distinct earthquake shocks were felt here last night at 10.15. The first was quite sharp, causing loose doors and windows to rattle. After a slight pause another shock occurred the two lasting in all about 20 seconds. No damage is reported.

Dauphin, Man., May 16 - Shortly after 10 o'clock on Saturday night two distinct earthquake shocks were felt here. They lasted from one to three seconds. Houses rocked and in numerous cases the contents were scattered about and the people rushed into the streets. In one instance a plater fell from the wall of a building. The shock was also felt in other parts of the district.

Invermax, Sask., May 16 - A slight earthquake shock was felt here last night at 9.25 , nearly every person in the village noticed the effect in one way or another. Dishes on the sidehoards rattled, and curtains were shaken. The shock was of very short duration.

McTaggart, Sask., May 16 - An unmistakable earthquake shock was felt here Saturday evening. A number of buildings were shaken and the crockery rattled. No damage is reported.

Portage la Prairie, Man., May 16 - The earthquake tremor which shook western Canada last night did not affect this city, and was not noticed so far as can be learned, except by one citizen.

Medicine Hat, Alta., May 16 - Two earthquake shocks were felt here last night. The vibrations were not sufficient to cause any damage but considerable fright was created as it was feared that these might be the precursors of others more violent. Numerous telephone messages were received from adjacent ranchers, who feared that an explosion had taken place in or near the city as it was understood that a large quantity of explosives had been stored in the suburbs.

Lamberg, Sask., May 16 - Slight disturbances occurred here last night about 10 o'clock and lasted several seconds. Two distinct shocks were felt and the buildings shook perceptibly. No damage has been reported.

\section{Records Not Developed.}

Ottawa, May 16 - On account of today being Sunday no seismograph records were developed at the Dominion observatory, and consequently it will not be known until to-morrow if the earthquake shock reported from the west was recorded here.

\section{The First on Record.}

Toronto, May 16 - The seismograph at the government observatory here was not examined to-day for a record of the earth tremor. An official despatch from Qu'Appelle to the observatory says "a slight 
earthquake shock was felt at 9.30 o'clock last night.” R. F. Stupart, the observatory director, says he cannot remember a seismic disturbance ever occurring in the northwest region before and is much surprised. The seismograph record will be examined to-morrow.

\section{SHOCK FELT IN MONTANA}

Helena, Mont., May 15 - Just recovered from an earthquake shocks which occurred here at 9.15 to-night and which lasted for several seconds, great alarm has been caused throughout the city by the receipt advices from many points to the north and south, telling of serious similar shocks which have been taking place throughout this section.

The shocks here lasted several seconds and were distinctly felt throughout the city. The older houses in the town shook violently, people rushed from their homes into the streets in wild bewilderment and for a time it was feared that serious damage had been done.

After some time it was ascertained that the only real damage was to a residence in the better section where a retaining wall was thrown down, causing the house to shift considerably. This wall was ten feet high and two feet thick and was built of brick and masonry and was intended to withstand great pressure.

\section{Tracks Torn Up.}

The extent of the damage done to other towns is not yet known, causing great anxiety among friends of people living in the towns where the disturbances are reported to have occurred.

Railroad men reaching here report that the Northern Pacific tracks have suffered to a considerable extent having been thrown up in several places for considerable distances.

From Glendive the report comes that very perceptible shocks were felt at 9.16 to-night. A number of men who were gathered in the Masonic temple at the time rushed from the building fearing it was about to fall. For some seconds the earth shook and the swaying of the Masonic temple, one of the largest in the city, was clearly perceptible.

\section{Wall Caves In.}

In many homes the dishes rattled in the pantries, pictures were shaken from the walls and large portions of plaster dropped to the floors near the demoralized occupants.

At Dickenson, N. D., it is said that the shocks were the most severe. The despatchers in the new depot their work frightened from their posts and were unable to return to their work for some time owing to the falling of a door and wall which came down with the trembling and rapid vibrations of the building.

The town of Glasgow on the Great Northern railroad was also shaken and for fully three minutes consternation reigned there. At Fryburg, N. D., the railway station was badly shaken by shocks which lasted for two minutes, according to the reports from the telegraph operator at that place. 


\section{ABOUT EARTHQUAKES}

It has been generally considered that no part of the world was so immune from the ravages of earthquakes, or even from their mere occurrence, as the central part of Canada, as well on account of the absence of volcanic disturbance from any coast line. It is well established that certain earthquakes are the direct concomitants of volcanic action. Lava in eruption contains a large quantity of steam, which under certain conditions may cause violent explosions, hurling vast masses of lava into the air. Such violent explosions may even blow off the entire top of a mountain, as in the great explosion of Krakatoa, in the Sunda straits, where what was formerly land is now covered by 150 fathoms of water. Such shocks have caused earthquakes, the effects of which have been felt over many miles. Again the lava forcing its way through the crust of the earth may form fissures in the solid rocks, which undoubtedly leads to earthquake shocks.

But other earthquakes are apparently not associated with volcanic action, and for those another explanation is necessary. A considerable amount of corrugation of the earth's crust has occurred for which various causes have been assigned. Whatever the cause it is certain that stresses have accumulated sufficiently to raise great mountain systems, and to bring about much deformation of the rocks of the earth's crust. It is reasonable to suppose that these stresses may at certain times and places accumulate to such an extent as to cause violent rupture, which would be felt as an earthquake shock. Te view is therefore taken by geologists that many earthquakes, perhaps even those associated with volcanic action are due to the readjustment of the earth's crust to changing conditions of pressure.

\section{Shocks Along Coast Line.}

The occurrence of earthquakes along coast lines probably carries out the latter theory. Coast lines are the boundaries between land and water. The constant washing of waves on these boundaries is responsible at times for the splitting of rock strata, and for a consequent "fault" appearing in the line of the strata, which may extend over a great surface of country. In readjusting itself the rock strata, in which the fault occurs, may drop a foot or more over the entire region affected, and the consequent disturbance in the earth's surface in that district may cause the ground to heave, and break open, and to engulf and destroy entire cities in the path of the quake. It is generally concede that it was such a fault as this in the strata underlying San Francisco which caused the devastation in 1906. The natural inclination of the strata from the horizontal on coast lines is thought to be largely responsible for the more frequent occurrences of earthquakes in countries near the sea.

Owing to the vast depth of the strata of the central part of Canada and the northern States geologists have been unable to ascertain to any degree of certainty, the nature of tat strata. In view of the level of character of the country, however, it is thought that it is fairly, if not altogether horizontal in nature, with little inclination toward the vertical in any part, and that thus there is less probability of "faults" or fissures occurring. Taking into consideration, then, the freedom of central Canada from volcanic disturbances and the additional fact that its strata is conceded to be comparatively horizontal, and free from "faults," there seems to be little danger of an earthquake originating here.

\section{No Guarantee of Exemption.}

These facts, however, do not altogether exempt the regions of central Canada, and the northern states, from being affected by earthquakes which may occur great distances away. An earthquake begins at some point of subterranean shock, called by scientists the "centrum," or "focus," and travels in waves with gradually diminishing energy in every direction from this point. One of those waves may travel over the chord of a circle coming out at the other side and causing another earthquake at the point where it leaves the earth's surface. In that case if its course is near to the earth's surface a tremor may be felt throughout the country under which it passes for many miles. The earthquake which occurred in northern India in 1905 was left in various parts of Europe, more than a week before it was known that devastation had been wrought at the place where it originated. The tremor from the earthquake at San Francisco was felt in Indiana.

It is very probable then, that the tremor which was felt here may have been caused by the waves resulting from the shock of some great earthquake which had occurred even as far south as South America or as far west as the coast line. The location of it may not be found until calculations are made from the records of the various seismographs stationed throughout the country. The fact that the shocks have been confined to a comparatively small area does not argue that the earthquake originated in that area. The shocks felt may be simply caused by the partially spent force of diverging waves from the centrum.

\section{Recording Instruments.}


The instruments which record the occurrence of earthquakes, and by which the centrum or focus is located are of much interest. The seismograph automatically records the time, violence and duration of exceedingly slight tremors. In some localities slight shakes, or "microseisms" have been found to be of daily occurrence, while in no part of the world are they altogether lacking. So delicate are these instruments that the pressure of a hand against a stone column on which they rest, will instantly cause a variation of the pointer, while the sag in the heart of a city during the heavy traffic of the day, and the sag of valleys between hills during heavy rainfall, are indicated. The centre of any disturbance may be quickly located by comparing the records of time and violence of the shock in different observatories passed by the wave in its course, and then with a globe and a pair of compasses, determining the point from which the wave would reach all of these observatories at he times recorded. This determination of focus of an earthquake is of much economic importance. These instruments are located at various observatories throughout America, there being one at Washington, one at Toronto, and one at Victoria, so that much interest will be felt as to the centre which will be located for the recent shock.

EARTHQUAKES SINCE 1880

About 100 - can be added to here although the paper does not continue down to show all

\section{$\underline{\text { Manitoba Free Press May } 181909}$}

\section{UPHEAVAL IN THE ROCKY MOUNTAINS}

\section{Minnesota Professor's Explanation of the Earth Shock Felt in Western Canada}

Minneapolis, Minn., May 17 - That the people of the Canadian prairies west of Winnipeg who were shaken out of their beds and received a general fright from an earthquake on Saturday night, were disturbed by a quake resulting from an upheaval in the Rocky Mountains, if the opinion of Frederick W. Sardeson, Ph. D., assistant professor of paleontology, in the University of Minnesota.

Professor Sardeson says: "The district affected is within the Rocky mountain region. The shaking of the earth was undoubtedly caused by an upheaval in these mountains, which it has been discovered are constantly rising, and an upheaval of some sort in that region probably started that long shake across the prairie. A range of mountains in Montana is, I believe, not far from the scene of the disturbance. The Black Hills are also a detached section of the Rocky mountains, and any change in them might cause a shake in the country around there. Any [art of the country west of the Missouri River is subject to earthquake disturbance.

"I do not agree," continued Mr. Sardeson, "with Professor Allen of Manitoba university, that the earthquake is a result of a larger one in South America. The interior of the earth is plastic, or solid, and earthquake waves could not travel through it any more than they would through dough. If the wave came from South America it would have travelled along the crust of the earth and in that case we at Minneapolis would have felt it too."

Ottawa May 17 - Dr. Elotz of the Dominion observatory, states that the seismograph records an earthquake shock 2,500 kilometres distant from Ottawa at 18 minutes 25 seconds after 11 o'clock Saturday night. It lasted half an hour. Another was recorded this morning at 7,000 kilometres distant from Ottawa which lasted two hours.

\section{Meteor at Melfort.}

Melfort, Sask., May 17 - A slight earthquake shock was felt here on Saturday at 9.20 p.m. though no alarm was shown by any one. A brilliant meteorite with a conspicuous tail passed over Melfort last evening at 7.20 o'clock from the south to the north.

\section{Recorded at Toronto.}

Toronto May 17 - The seismograph at the Toronto observatory registered a slight movement at 11 hours 27 minutes on Saturday evening, which would correspond to 9 hours 27 minutes in the western provinces. A strong earthquake was also recorded on Monday morning. May 17 at 3 hours 12.8 minutes 
lasting 1 hour and 32 minutes. The large waves were recorded at 3 hours 21.5 minutes continuing about ten minutes. The semi-amplitud of the disturbance was four millimetres and it is estimated that the distance of the earthquake from Toronto was 7,750 kilometeres.

"It must have been quite a movement to send tremors here," said Director Stupart of the observatory. "It likely was centred in western Canada of the western States, but our record here is so slight that there are no phases of the movement to give us any indication of where the earthquake was. Western Canada is an extremely unlikely place for an earthquake, and therefore this one has come as quite a surprise."

\section{Govan Relt It.}

Govan, Sask., May 17 - An earthquake shock was felt in Govan Saturday, but no damage resulted. Slight Vibration at Calgary.

Calgary, Alta., May 17 - If it had not been for outside reports and the presence in the city of Californians who are earthquake experts, Calgary would not have known there had been a shock Saturday. A slight vibration at 9.30 was noticed by some, but it was given no thought, as it was like the passing of a heavy wagon on the pavement.

\section{Tremor at Hamiota.}

Hamiota, Man., May 17 - A slight tremor of the earth was felt here on Saturday evening at 10.15, which lasted several seconds. No damage resulted from the shock but a great many people were disturbed out of their usual serenity of mind by this unusual and unaccountable occurrence.

\section{Caused Alarm at Aberdeen.}

Aberdeen, Sask., May 17 - A distinct trembling of the earth resembling an earthquake and accompanied by a rumbling noise, was felt here a few minutes past nine Saturday night. NO damage is reported, but the people were considerably alarmed for a time.

\section{Felt in Kamsack.}

Kamsack, Sask., May 17 - Saturday night about 10.20 o'clock a distinct tremor of the earth was felt here by the residents of this place. The shock was of slight duration lasting only about five seconds.

\section{Startled People at Kennedy.}

Kennedy, Sask., May 17 - Shocks similar to an earthquake were distinctly felt here Saturday night at about 10.20. Several houses and stores were shaken and furniture, lamps, etc., swayed considerably, startling the residents. The shock was of very short duration. No damage is reported.

\section{Decided Shock at Rosthern.}

Rosthern, Sask., May 17 - An earthquake shock was felt at Rosthern about ten minutes after nine Saturday evening. Many houses were shaken, and articles in the buildings were moved around considerably. Even pianos worked. Several people living down town rushed form the buildings they occupied, being badly frightened. No damage is reported.

Lasted Two Minutes at Montmartre.

Montmartre, Sask., May 17 - An earthquake shock was felt here on May 15 at 10 p.m. It lasted two minutes. No damage was done.

\section{Tisdale Got Double Scare.}

Tisdale, Sask., May 17 - A slight shock was experienced here on Saturday evening at 9.20, there were two distinct motions. A slight upheaval followed by general tremor which lasted about 5 seconds. No damage is reported. On Sunday evening at 5.15 a meteor was seen to shoot across the sky. It then split and an explosion took place resembling dynamite blasts. After the experience of the previous evening this phenomenon caused some alarm.

\section{Horses Break Halters.}

Dysart, Sask., May 17 - A severe shock was felt here between the hours of 9 and 10 on Saturday night, and the hotel fairly rocked for about two minutes. There was also a rumbling sound during the period of the shock. Farmers for four or five miles around felt the shock and in some cases horses broke their halters in the stables. 


\section{Earthquake Felt at Gretna.}

Gretna, Man., May 18 - The earthquake was felt here by many persons. [_ $\}$ of the people were in bed and re[_ceived?] quite a shock. so much so that [_ ] [ got?] up and made an inspection for [ _ ] to their buildings. thinking [_their?_] foundations had given way.

\section{Manitoba Free Press - Winnipeg May 211909}

\section{SEISMOGRAPH}

\section{St. Boniface College Will Put in Modern Earthquake Recorder.}

Winnipeg is talking lost just now about the advancement of science and when August brings the British scientists to its gates it will talk for whole days about it. In the meantime St. Boniface, which is popularly supposed to be some centuries behind in the matter of scientific advancement, is actually doing things. Last year the Jesuit college over the river installed the most powerful telescope in western Canada, and now the announcement come that it will install the first seismograph on the western prairies.

In the current number of "Le Manitoba" Father Blain, S. J., science instructor at St. Boniface college, writes that for some days previous to the earthquake the college authorities had been considering the purchase of a seismograph when bang came the earthquake. With this cogent reminder Father Blain says that the college authorities have now practically decided to install a modern seismograph. This instrument will form part of a meterological observatory, which the college hopes to possess at an early date. The Jesuit fathers have already established meteorological observatories in fifteen of their colleges, situated in different parts of the North American continent.

With regard to the recent earthquakes Father Blain writes as follows: "The earthquake which has visited us was a feeble one. If one adopts the classification of earthquakes according to intensity, using numbers one to ten, that of Saturday would come in class three or four. Here is the description of these two classes in the system Rassi-Forel to which I have referred:

“" 'Class 3 - Shock very feeble: is felt by many persons in bed. is sufficiently pronounced, however, for its duration and direction to be observed.'

" 'Class 4 - Shock feeble: is felt by many persons in movement. is characterized by rattling of furniture, doors, windows and by the cracking of ceilings.'

"But, it will perhaps be asked, are these earthquakes still more feeble than those earthquakes which are scarcely perceptible? Yes, certainly, there are many earthquakes which are only perceptible by delicate instruments called seismographs or seismometers. Their acuteness goes far beyond our senses. it is just the same in astronomy. In which glasses reveal to us starts invisible to the naked eye. A good eye, unaided can perceive about 5,000 stars, but with the most powerful instruments one can count 140,000,000 stars." 